Nevada

DOE/NV--555

Environmental

Restoration

Project

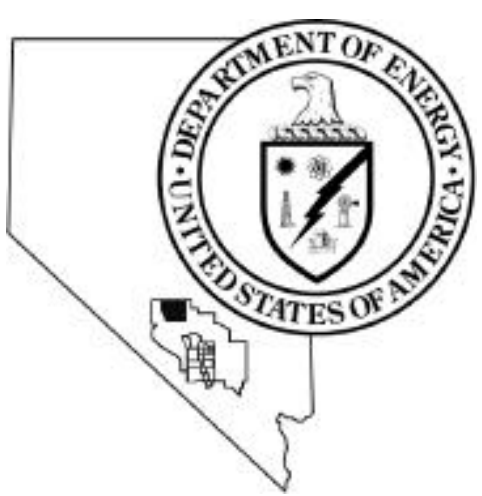

Corrective Action Decision Docum ent for Corrective Action Unit 486 :

Double Tracks RADSAFE Area,

$\mathrm{N}$ ellis Air Force Range, $\mathrm{N}$ evada

Controlled Copy N $0 .:-$

Revision N 0.: 0

J une 1999

Approved for public release; further distribution is authorized.

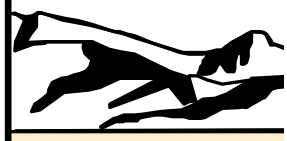

Environm ental Restoration

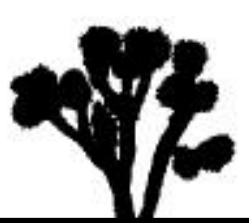

Division 
Available to the public from -

\section{U.S. Department of Commerce}

National Technical Information Service

5285 Port Royal Road

Springfield, VA 22161

(703) 487-4650

Available electronically at http://www.doe.gov/bridge. Available to U.S. Department of Energy and its contractors in paper from -

U.S. Department of Energy

Office of Scientific and Technical Information

P.O. Box 62

Oak Ridge, TN 37831-0062

(423) 576-8401

Reference herein to any specific commercial product, process, or service by trade name, trademark, manufacturer, or otherwise, does not necessarily constitute or imply its endorsement, recommendation, or favoring by the United States Government or any agency thereof or its contractors or subcontractors. 


\title{
CORRECTIVE ACTION DECISION DOCUMENT FOR CORRECTIVE ACTION UNIT 486: DOUBLE TRACKS RADSAFE AREA, NELLIS AIR FORCE RANGE, NEVADA
}

\author{
DOE Nevada Operations Office \\ Las Vegas, Nevada
}

Controlled Copy No.:

Revision No.: 0

June 1999

Approved for public release; further distribution is authorized. 


\section{CORRECTIVE ACTION DECISION DOCUMENT \\ FOR CORRECTIVE ACTION UNIT 486: \\ DOUBLE TRACKS RADSAFE AREA, NELLIS AIR FORCE RANGE, NEVADA}

Approved by:

Signature Approved

Date:

$6 / 23 / 99$

Janet Appenzeller-Wing, Project Manager

Industrial Sites Project

Approved by:

Signature Approved

Date:

$6 / 23 / 99$

Runore C. Wycoff, Division Director

Environmental Restoration Division 


\section{Table of Contents}

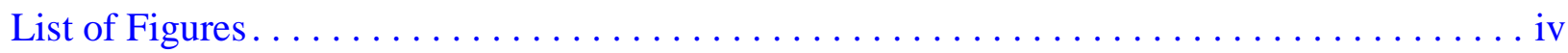

List of Tables. . . . . . . . . . . . . . . . . . . . . . . . . .

List of Acronyms and Abbreviations $\ldots \ldots \ldots \ldots \ldots \ldots \ldots \ldots \ldots \ldots \ldots \ldots \ldots \ldots \ldots \ldots$

Executive Summary . . . . . . . . . . . . . . . . . . . . . . . . . . ES-1

$1.0 \quad$ Introduction $\ldots \ldots \ldots \ldots \ldots \ldots \ldots \ldots \ldots \ldots \ldots \ldots \ldots \ldots \ldots \ldots \ldots \ldots$

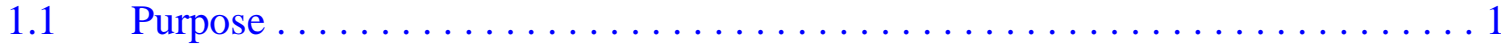

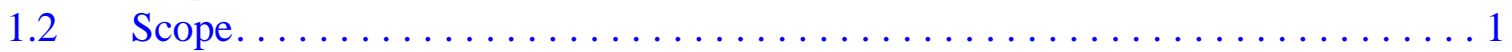

$1.3 \quad$ CADD Contents $\ldots \ldots \ldots \ldots \ldots \ldots \ldots \ldots \ldots \ldots \ldots \ldots \ldots \ldots$

2.0 Corrective Action Investigation Summary $\ldots \ldots \ldots \ldots \ldots \ldots \ldots \ldots \ldots \ldots \ldots \ldots \ldots \ldots$

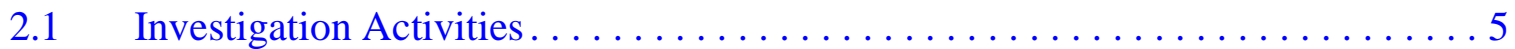

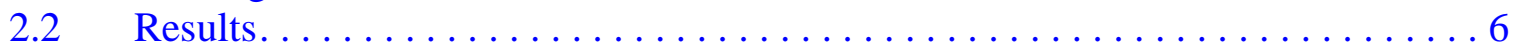

$2.3 \quad$ Need for Corrective Action. . . . . . . . . . . . . . . . . . 7

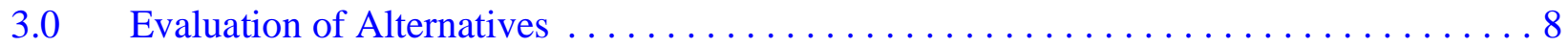

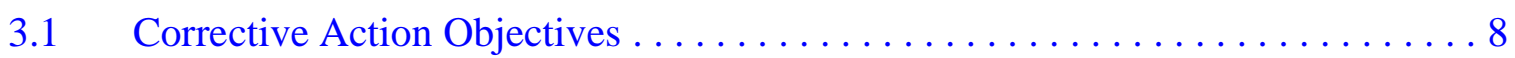

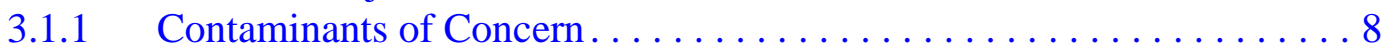

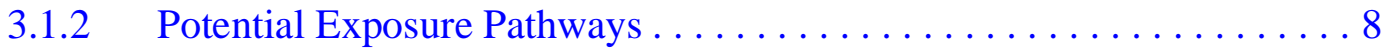

$3.2 \quad$ Screening Criteria . . . . . . . . . . . . . . . . . . . . 9

3.2.1 Corrective Action Standards. . . . . . . . . . . . . . . . . . 9

3.2.2 Remedy Selection Decision Factors. . . . . . . . . . . . . . . . . 11

3.3 Development of Corrective Action Alternatives $\ldots \ldots \ldots \ldots \ldots \ldots \ldots \ldots$

3.3.1 Alternative 1 - No Further Action . . . . . . . . . . . . . . 13

3.3.2 Alternative 2 - Clean Closure by Excavation and Disposal . . . . . . . 13

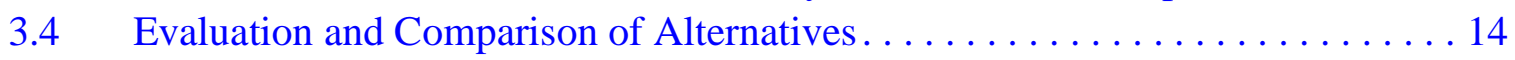

$4.0 \quad$ Recommended Alternative $\ldots \ldots \ldots \ldots \ldots \ldots \ldots \ldots \ldots \ldots \ldots \ldots \ldots \ldots$

$5.0 \quad$ References....................................... 18

Appendix A - Corrective Action Investigation Report for CAU 486:

Double Tracks RADSAFE Area, Nellis Air Force Range, Nevada

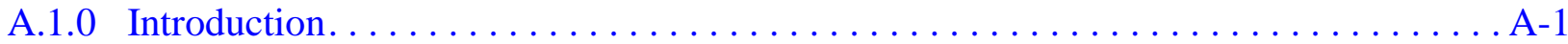

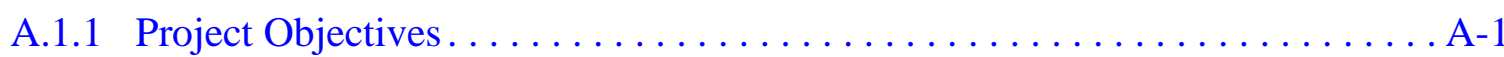

A.1.2 Report Content . ............................ A-2 


\section{Table of Contents (Continued)}

A.2.0 Field Investigation and Sampling Activities. . . . . . . . . . . . . A-3

A.2.1 Site Description and Conditions . . . . . . . . . . . . . . A-4

A.2.2 Investigation Logistics . . . . . . . . . . . . . . . . . . A-6

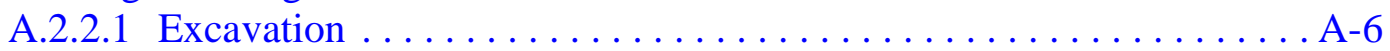

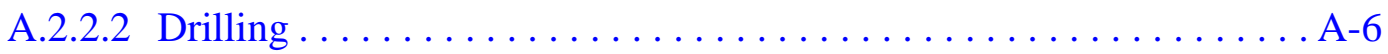

A.2.2.3 Southern Half of DTRSA . . . . . . . . . . . . . . . . A-9

A.2.2.4 Area 2 Investigation . . . . . . . . . . . . . . . A-11

A.2.2.5 Area 6 Investigation . . . . . . . . . . . . . . . . . . A-11

A.2.3 Field Screening . . . . . . . . . . . . . . . . . . . . . . . A-14

A.2.4 Sample Collection. . . . . . . . . . . . . . . . . . . . . . A-15

A.2.5 Waste Management. . . . . . . . . . . . . . . . . . . . A 16

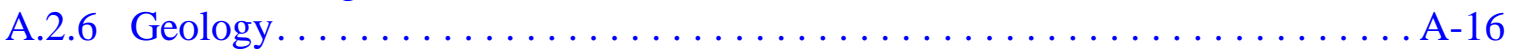

A.2.7 Hydrology . . . . . . . . . . . . . . . . . . . A 17

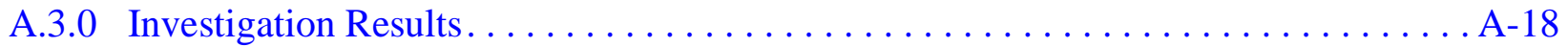

A.3.1 Total Volatile Organic Compound Analytical Results. . . . . . . . . . . . . . A-18

A.3.2 Total Semivolatile Organic Compound Analytical Results . . . . . . . . . . A A-22

A.3.3 Total Petroleum Hydrocarbon Results . . . . . . . . . . . . . . . A-22

A.3.4 Total RCRA Metals Results ... . . . . . . . . . . . . . . . . A-24

A.3.5 Isotopic Plutonium and Uranium Results . . . . . . . . . . . . . A-24

A.3.6 Geotechnical Analysis Results . . . . . . . . . . . . . . . A-24

A.4.0 Quality Assurance. .............................. A-30

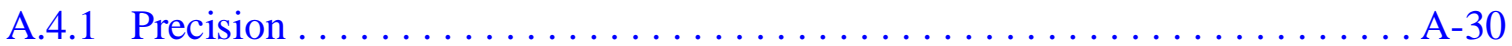

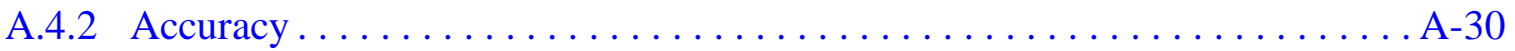

A.4.3 Representativeness . . . . . . . . . . . . . . . . . . . .

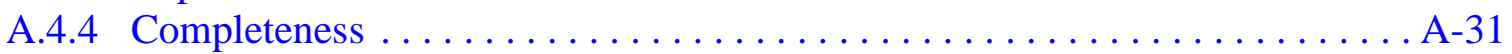

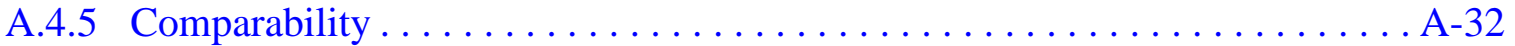

A.4.6 Tier I and Tier II Data Evaluations. . . . . . . . . . . . . . . . A-32

A.4.6.1 Tier I Evaluation. . . . . . . . . . . . . . . . . . . . A-32

A.4.6.2 Tier II Evaluation . . . . . . . . . . . . . . . . . A-33

A.4.6.3 Tier III Evaluation $\ldots \ldots \ldots \ldots \ldots \ldots \ldots \ldots \ldots \ldots \ldots . \ldots \ldots$ A $\ldots \ldots \ldots$

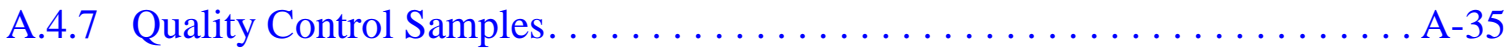

A.4.7.1 Field Quality Control Samples . . . . . . . . . . . . . . . A-35

A.4.7.2 Laboratory Quality Control Samples . . . . . . . . . . . . . . A-36

A.4.8 Field Nonconformances . . . . . . . . . . . . . . . . . . . A-39

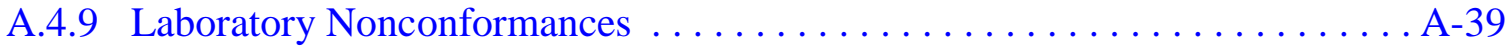




\section{Table of Contents (Continued)}

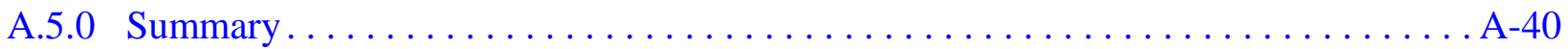

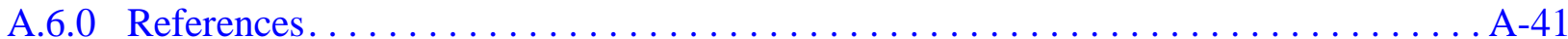

Appendix B - Soil Boring Logs

Appendix C - Cost Estimates

Appendix D - Response to NDEP Comments 


\section{List of Figures}

Number

1-1 Nellis Air Force Range 71 North and Tonopah Test Range Location Map . . . . . . 2

1-2 Location of CAU 486, Double Tracks RADSAFE Area

Range 71 North, Nellis Air Force Range, Nye County, Nevada . . . . . . . . . . . . 3

A.2-1 Investigation Locations for DTRSA $\ldots \ldots \ldots \ldots \ldots \ldots \ldots \ldots \ldots \ldots$

A.2-2 Excavation and Borehole Locations for the South Side Investigation of DTRSA

A.2-3 Excavation and Borehole Locations for the North Side Investigation

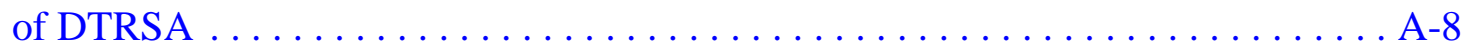

A.2-4 Uncovered Debris in Trench $6 \mathrm{NT} 1 \ldots \ldots \ldots \ldots \ldots \ldots \ldots \ldots \ldots \ldots \ldots$. . . . . . . . . . . . . . 


\section{List of Tables}

Number

3-1 Detailed Evaluation of Alternatives. . . . . . . . . . . . . . . . . . . 15

3-2 Comparative Evaluation of Alternatives ..................... 16

A.3-1 Samples Collected and Analyzed During the DTRSA Subsurface Investigation . . A-19

A.3-2 Laboratory Analytical Methods Used for the DTRSA Investigation Samples . . . A-22

A.3-3 Soil Sample Results for Total Volatile Organic Compounds Detected Above Minimum Reporting Limits, Double Tracks RADSAFE Area, Nellis Air Force Range . . . . . . . . . . . . . . . . . . . . . A-23

A.3-4 Soil Sample Results for Total RCRA Metals Detected Above Minimum Reporting Limits, Double Tracks RADSAFE Area, Nellis Air Force Range . . . . A-25

A.3-5 Soil Sample Results for Isotopic Plutonium and Isotopic Uranium Detected above Minimum Reporting Limits, Double Tracks RADSAFE Area, Nellis Air Force Range 


\section{List of Acronyms and Abbreviations}

\begin{tabular}{|c|c|}
\hline bgs & Below ground surface \\
\hline CADD & Corrective Action Decision Document \\
\hline CAIP & Corrective Action Investigation Plan \\
\hline CAS & Corrective Action Site \\
\hline CAU & Corrective Action Unit \\
\hline CFR & Code of Federal Regulations \\
\hline CLP & Contract Laboratory Program \\
\hline $\mathrm{cm}^{2}$ & Square centimeter(s) \\
\hline $\mathrm{COC}$ & Contaminant(s) of concern \\
\hline $\mathrm{COPC}$ & Contaminant(s) of potential concern \\
\hline cpm & Count(s) per minute \\
\hline CRDL & Contract-required detection limit(s) \\
\hline $\mathrm{DOE} / \mathrm{NV}$ & U.S. Department of Energy, Nevada Operations Office \\
\hline dpm & Disintegration(s) per minute \\
\hline DQO & Data Quality Objectives \\
\hline DTRSA & Double Tracks RADSAFE Area \\
\hline EPA & U.S. Environmental Protection Agency \\
\hline FFACO & Federal Facility Agreement and Consent Order \\
\hline FIDLER & Field Instrument for the Detection of Low Energy Radiation \\
\hline FSL & Field screening level(s) \\
\hline $\mathrm{ft}$ & Feet (foot) \\
\hline $\mathrm{ft}^{2}$ & Square feet (foot) \\
\hline HWAA & Hazardous Waste Accumulation Area \\
\hline IDW & Investigation-derived waste \\
\hline in. & $\operatorname{Inch}(\mathrm{es})$ \\
\hline LCS & Laboratory control samples \\
\hline
\end{tabular}




\section{List of Acronyms and Abbreviations (Continued)}

$\begin{array}{ll}\text { MARSSIM } & \text { Multi-Agency Radiation Survey and Site Investigation Manual } \\ \mathrm{mg} / \mathrm{kg} & \text { Milligram(s) per kilogram } \\ \mathrm{mi} & \text { Mile(s) } \\ \text { MS/MSD } & \text { Matrix spike/matrix spike duplicate } \\ \text { NAC } & \text { Nevada Administrative Code } \\ \text { NDEP } & \text { Nevada Division of Environmental Protection } \\ \text { NIST } & \text { National Institute for Standards and Technology } \\ \text { NRS } & \text { Nevada Revised Statutes } \\ \text { PAL } & \text { Preliminary action level(s) } \\ \text { ppm } & \text { Part(s) per million } \\ \text { PID } & \text { Photoionization detector } \\ \text { PRG } & \text { Preliminary remediation goal(s) } \\ \text { QA } & \text { Quality assurance } \\ \text { QAPP } & \text { Industrial Sites Quality Assurance Project Plan } \\ \text { QC } & \text { Quality control } \\ \text { RADSAFE } & \text { Radiological Safety Area } \\ \text { RCRA } & \text { Resource Conservation and Recovery Act } \\ \text { RMA } & \text { Radioactive Materials Area } \\ \text { RPD } & \text { Relative percent difference } \\ \text { SB } & \text { South Boring } \\ \text { SDG } & \text { Sample delivery group } \\ \text { ST } & \text { South Trench } \\ \text { SVOC } & \text { Semivolatile organic compound(s) } \\ \text { TPH } & \text { Total petroleum hydrocarbons } \\ \text { TTR } & \text { Tonopah Test Range } \\ \text { VOC } & \text { Volatile organic compound(s) } \\ & \end{array}$




\section{List of Acronyms and Abbreviations (Continued)}

$\begin{array}{ll}\text { UXO } & \text { Unexploded ordnance } \\ \% \mathrm{R} & \text { Percent recovery }\end{array}$




\section{Executive Summary}

This Corrective Action Decision Document has been prepared for the Double Tracks Radiological Safety Area (Corrective Action Unit 486) in accordance with the Federal Facility Agreement and Consent Order (FFACO, 1996). Corrective Action Unit 486 is located at the Nellis Air Force Range 71 North and is comprised of Corrective Action Site 71-23-001-71DT. The purpose of this Corrective Action Decision Document is to identify and provide a rationale for the selection of a recommended corrective action alternative for Corrective Action Unit 486.

The scope of this Correction Action Decision Document consists of the following:

- Develop corrective action objectives.

- Identify corrective action alternative screening criteria.

- Develop corrective action alternatives.

- Perform detailed and comparative evaluations of the corrective action alternatives in relation to the corrective action objectives and screening criteria.

- Recommend and justify a preferred corrective action alternative for the Corrective Action Unit.

In November and December 1998, a corrective action investigation was performed as set forth in the Corrective Action Investigation Plan for Corrective Action Unit 486: Double Tracks RADSAFE Area, Nellis Air Force Range, Nevada (DOE/NV, 1998). Radiological field screening during Phase I activities detected elevated gamma readings above the established field screening levels on excavated gravel and elevated gamma and alpha readings on excavated plastic debris. Swipe surveys taken on the plastic debris detected removable alpha. No contaminants were detected above preliminary action levels in soil samples analyzed from Phase II activities. Debris excavated during Phase I activities was not characterized. Details of the investigation can be found in Appendix A of this document. 
Based on the potential exposure pathways identified during the Data Quality Objectives process, the following corrective action objectives have been identified for Corrective Action Unit 486:

- Prevent or mitigate human exposure to buried man-made debris.

- Prevent spread of contaminated man-made debris beyond the CAU.

Based on the review of existing data, future land use assumption, and current operations at the Nellis Air Force Range, the following alternatives were developed for consideration at the Double Tracks Radiological Safety Area:

- Alternative 1 - No Further Action

- Alternative 2 - Clean Closure by Excavation and Disposal

The corrective action alternatives were evaluated based on four general corrective action standards and five remedy selection decision factors. Based on the results of this evaluation, the preferred alternative for Corrective Action Unit 486 is Alternative 2, Clean Closure by Excavation and Disposal.

The preferred corrective action alternative was evaluated on technical merit, focusing on performance, reliability, feasibility, and safety. The alternative was judged to meet all requirements for the technical components evaluated. The alternative also meets all applicable state and federal regulations for closure of the site and will reduce potential future exposure pathways.

During corrective action implementation, this alternative will present a potential threat to site workers who come in contact with contaminated man-made debris. However, procedures will be developed and implemented to ensure worker health and safety. 


\subsection{Introduction}

This Corrective Action Decision Document (CADD) has been prepared for Corrective Action Unit (CAU) 486, Double Tracks Radiological Safety (RADSAFE) Area (DTRSA) in accordance with the Federal Facility Agreement and Consent Order (FFACO) of 1996 that was agreed to by the U.S. Department of Energy, Nevada Operations Office (DOE/NV); the Nevada Division of Environmental Protection (NDEP); and the U.S Department of Defense (FFACO, 1996). The CADD provides or references the specific information necessary to recommend a preferred corrective action for the single Corrective Action Site (CAS), 71-23-001-71DT, within CAU 486.

Corrective Action Unit 486 is located on the Nellis Air Force Range 71 North, west of the Tonopah Test Range (TTR), Nevada. The TTR, located in the Nellis Air Force Range, is approximately 140 miles (mi) northwest of Las Vegas, Nevada (Figure 1-1). The DTRSA is located on the west side of the Cactus Range approximately $5 \mathrm{mi}$ southwest of the Cactus Spring gate at the intersection of the Cactus Spring Road and the Double Tracks Control Point Road (Figure 1-2).

\subsection{Purpose}

This CADD identifies potential corrective action alternatives and provides a rationale for the selection of a recommended alternative for the CAU. The need for these alternatives is based on process knowledge and the results of investigative activities conducted in accordance with the Corrective Action Investigation Plan for Corrective Action Unit No. 486: Double Tracks RADSAFE Area, Nellis Air Force Range, Nevada (DOE/NV, 1998).

\subsection{Scope}

The scope of this CADD consists of the following:

- Develop corrective action objectives.

- Identify corrective action alternative screening criteria.

- Develop corrective action alternatives. 


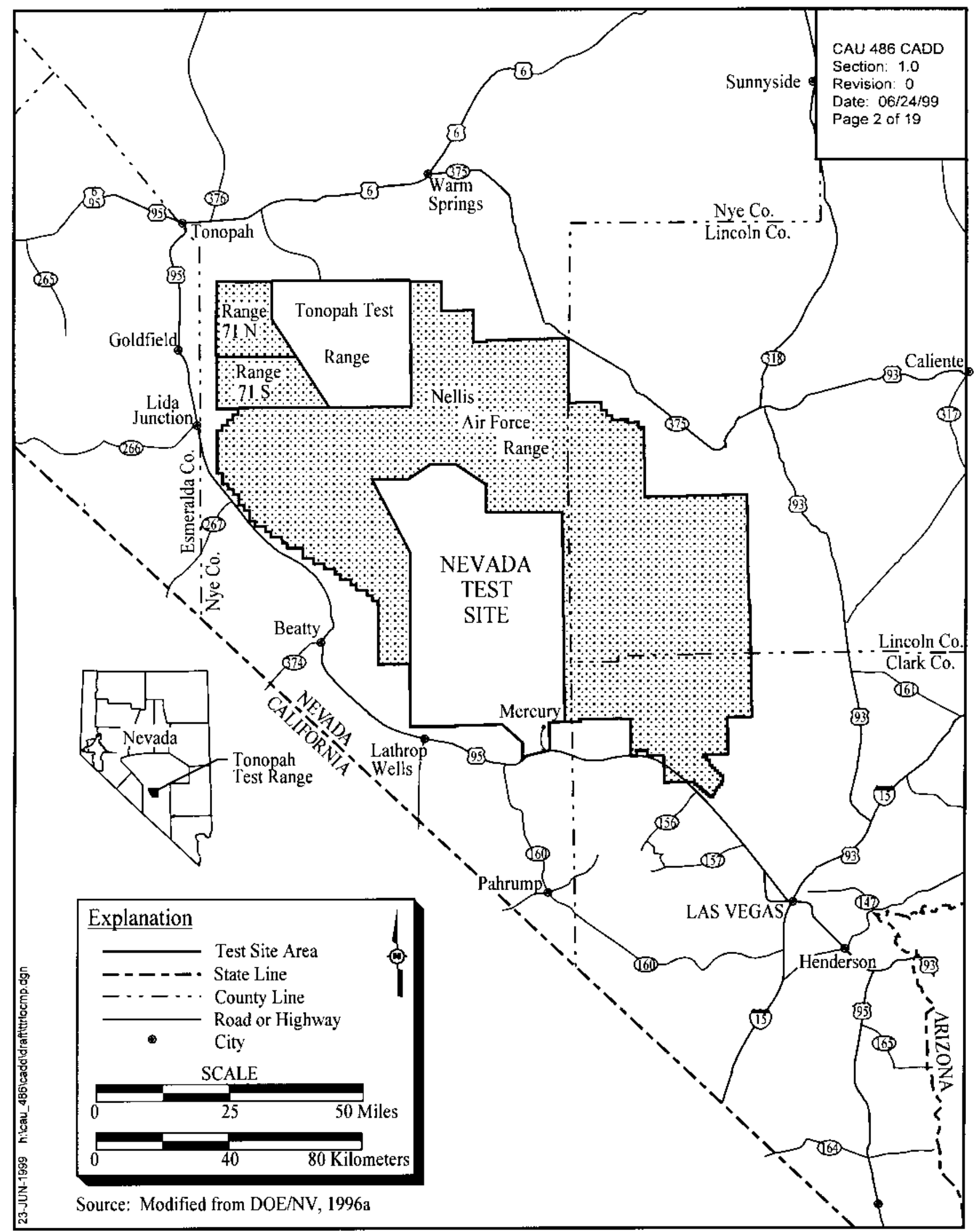

Figure 1-1

Nellis Air Force Range 71 North and Tonopah Test Range Location Map 


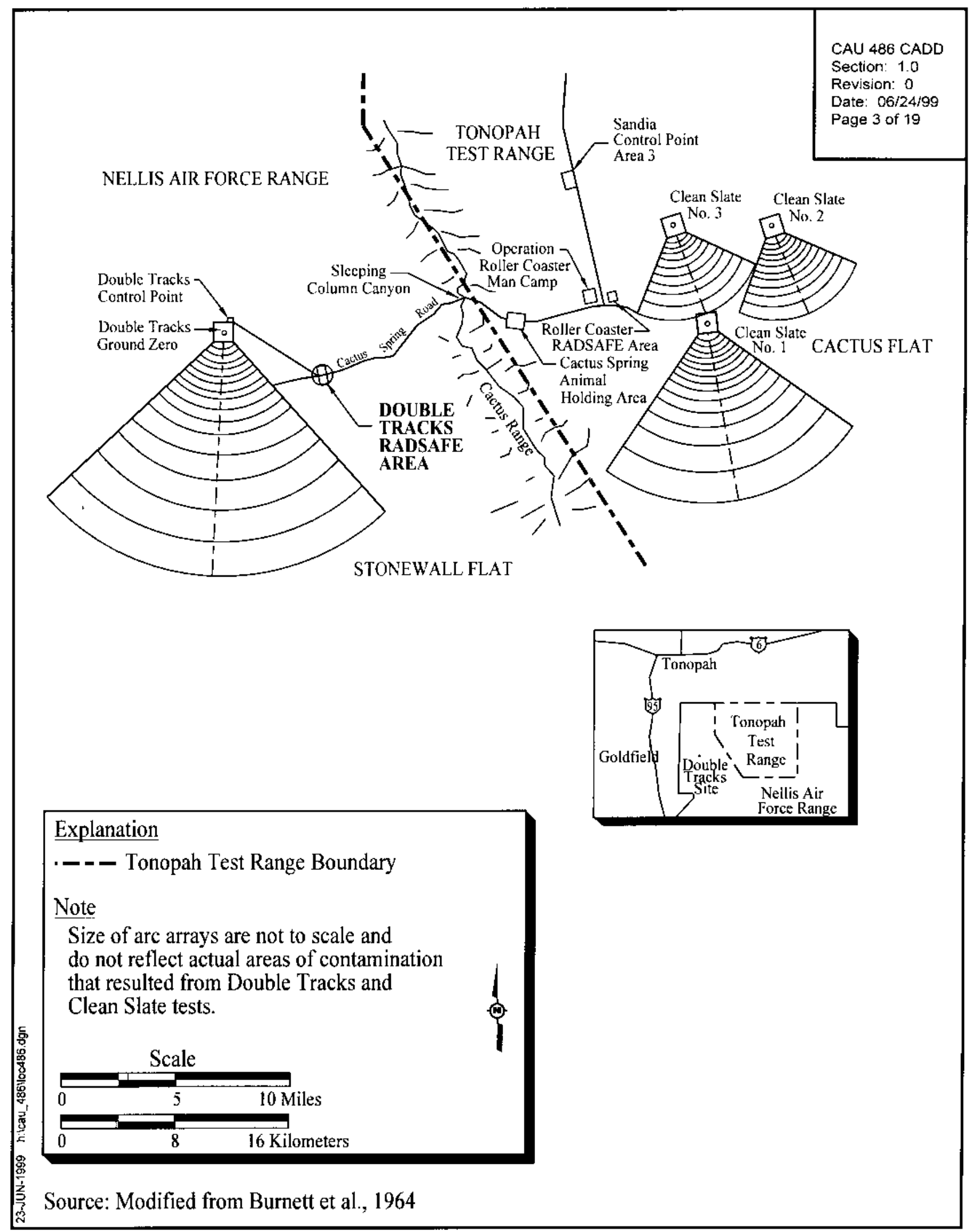

Figure 1-2

Location of CAU 486, Double Tracks RADSAFE Area Range 71 North, Nellis Air Force Range, Nye County, Nevada 
- Perform detailed and comparative evaluations of corrective action alternatives in relation to corrective action objectives and screening criteria.

- Recommend and justify a preferred corrective action alternative for the CAU.

\subsection{CADD Contents}

This CADD is divided into the following sections:

- Section 1.0 - Introduction: summarizes the purpose, scope, and contents of this CADD.

- Section 2.0 - Corrective Action Investigation Summary: summarizes the investigation field activities, the results of the investigation, and the need for corrective action.

- Section 3.0 - Evaluation of Alternatives: documents steps taken to determine a preferred corrective action alternative.

- Section 4.0 - Recommended Alternative: presents the preferred corrective action alternative and the rationale for its selection based on the corrective action objectives and alternative screening criteria.

- Section 5.0 - References: provides a list of all referenced documents.

- Appendix A: Corrective Action Investigation Report for CAU 486: Double Tracks RADSAFE Area, Nellis Air Force Range.

- Appendix B: Soil Boring Logs.

- Appendix C: Cost Estimates.

All work was performed in accordance with the following documents:

- Corrective Action Investigation Plan for Corrective Action Unit No. 486: Double Tracks RADSAFE Area, Nellis Air Force Range, Nevada, DOE/NV--523 (DOE/NV, 1998)

- Industrial Sites Quality Assurance Project Plan, DOE/NV--372 (DOE/NV, 1996b)

- $\quad$ Corrective Action Unit Work Plan for the Tonopah Test Range, DOE/NV--443 (DOE/NV, 1996a)

- $\quad$ FFACO (FFACO, 1996)

- Project Management Plan (DOE/NV, 1994) 


\subsection{Corrective Action Investigation Summary}

The following sections describe and summarize the results of the investigation activities conducted at CAU 486. For detailed investigation results, please refer to Appendix A.

\section{$2.1 \quad$ Investigation Activities}

Corrective action investigation activities were performed as set forth in the Corrective Action Investigation Plan (CAIP) (DOE/NV, 1998) from November 16 through December 4, 1998, in two separate phases. The purpose of the investigation was to:

- Identify and verify the boundaries of a decontamination facility and an animal burial pit within the DTRSA.

- Identify the presence and the vertical and lateral extent of contaminants of potential concern (COPCs), specifically radionuclides (e.g., plutonium, depleted uranium).

- Provide sufficient information and data to develop appropriate corrective action alternatives for the DTRSA.

Phase I was the identification of boundaries by trenching for both the decontamination facility and the animal burial pit. Phase II was the subsurface investigation consisting of soil sample collection. The activities for each phase are summarized below:

Phase I:

- Excavated a total of four trenches and nine step-out trenches on the south side of the DTRSA.

- Excavated a total of four trenches in Area 2 and six trenches in Area 6 on the north side of the DTRSA (Figure A.2-2 shows excavation locations).

- Conducted field screening of soil samples for radiological constituents and volatile organic compounds (VOCs). 
Phase II:

- Drilled two vertical background boreholes.

- Drilled eight vertical investigation boreholes (Figure A.2-3 shows borehole locations).

- Conducted field screening of soil samples for radiological constituents and VOCs.

- Collected background samples, environmental samples, and quality control (QC) samples for laboratory analysis. Samples were analyzed for some or all of the following: total VOCs, total semivolatile organic compounds (SVOCs), total petroleum hydrocarbons (TPH)-gasoline, TPH-diesel/oil, total Resource Conservation and Recovery Act (RCRA) metals, isotopic plutonium, and isotopic uranium.

- Collected soil samples for geotechnical analysis. Samples were not submitted for analysis.

- Logged soil cuttings to assess site geology.

\subsection{Results}

Details of the methods used and results found during the investigation are presented in Appendix A.

The corrective action investigation results indicated the following:

- Man-made debris was found in Area 6 north trench number 1 (6NT1). The debris consisted of chicken wire, pieces of lumber, and plastic bags filled with miscellaneous material including a "contaminated material" sticker and pieces of what appeared to be cloth. The debris was left in place and recovered with soil.

- Total VOCs and SVOCs were either not present above the minimum reporting limits or, if present, were below the preliminary action levels (PALs).

- Total petroleum hydrocarbons were not detected in the gasoline or diesel ranges above the minimum reporting limits as specified in the CAIP (DOE/NV, 1998).

- Total RCRA metal results were all below the PALs except for arsenic. The reported concentrations were not significantly different than those in the background borehole and are considered representative of ambient conditions (Shacklette and Boerngen, 1984).

- Radiological field screening during Phase I activities detected elevated gamma readings above the established field-screening levels (FSLs) on excavated gravel in south trench number 4 (ST4) and elevated gamma and alpha readings on excavated plastic debris in 6NT1. Swipe surveys taken on excavated gravel in ST4 detected no removable 
contamination. Swipe surveys taken on the plastic debris in 6NT1 detected removable alpha. Swipe samples on the surrounding soil, fill material, and other debris (i.e., chicken wire and lumber) associated with 6NT1 were not elevated above the FSLs.

- Plutonium and uranium in the soil were either not present above the minimum reporting limits or, if present, were below the PALs.

\subsection{Need for Corrective Action}

Analytes detected during the corrective action investigation were evaluated against preliminary action levels to determine contaminants of concern (COCs) for CAU 486.

No analytes were detected above PALs as defined in the CAIP (DOE/NV, 1998). No COCs were identified for CAU 486.

- Excavated plastic debris in 6NT1 had elevated gamma and alpha readings above the established FSLs. Swipe surveys taken on the plastic debris in 6NT1 detected removable alpha.

- Excavated gravel in ST4 had elevated gamma readings above the established FSLs; however, swipe surveys taken on this excavated gravel detected no removable contamination.

- Neither the man-made debris nor the gravel was sampled for characterization.

Process knowledge indicates that the site was used for decontamination and solid waste disposal activities. The site received waste prior to the enactment of regulations pertaining to Class III solid waste facilities (e.g., Nevada Administrative Code [NAC] 444 [NAC, 1996a]). This site was never permitted under these regulations; therefore, it does not have to meet these requirements. However, to be protective of human health and the environment from potential hazards associated with the debris, corrective actions will be evaluated. 


\subsection{Evaluation of Alternatives}

The purpose of this section is to present the corrective action objectives for CAU 486, describe the general standards and decision factors used to screen the corrective action alternatives, and develop and evaluate a set of corrective action alternatives that could be used to meet the corrective action objectives.

\subsection{Corrective Action Objectives}

The corrective action objectives are media-specific goals for protecting human health and the environment. Based on the potential exposure pathways (see Section 3.1.2), the following corrective action objectives have been identified for CAU 486:

- Prevent or mitigate human exposure to subsurface soil containing contaminated man-made debris.

- Prevent spread of contaminated man-made debris beyond the CAU.

\subsubsection{Contaminants of Concern}

Contaminants of potential concern were determined in the Data Quality Objectives (DQO) process as outlined in the CAIP (DOE/NV, 1998). Analytical results obtained from the corrective action investigation were evaluated to determine if COPCs were detected above PALs and, therefore, would be COCs for CAU 486 that must be addressed by corrective action. Based on the results of this evaluation, and with the exception of the uncharacterized debris excavated from Area 6 , no COCs were identified above PALs (see Section A.3.0 of Appendix A).

\subsubsection{Potential Exposure Pathways}

As identified in the DQO process, the future land use for the DTRSA area is assumed to be continued use as a bombing range. As part of the CAIP (DOE/NV, 1998), a conceptual model for CAU 486 was developed which identified the potential exposure pathway as ingestion of soils under occupational scenarios (see Table A.3-2 in the CAIP [DOE/NV, 1998]). This pathway includes inhalation of particulates and dermal contact. 
Buried contaminated man-made debris is located at the site. The site is located on an inactive portion of the Nellis Air Force Range. The contaminated debris may be exposed from inadvertent bombing or erosion.

\subsection{Screening Criteria}

The screening criteria used to evaluate and select the preferred corrective action alternatives are identified in the U.S. Environmental Protection Agency (EPA) Guidance on Resource Conservation and Recovery Act (RCRA) Corrective Action Decision Documents (EPA, 1991) and the Final RCRA Corrective Action Plan (EPA, 1994).

Corrective action alternatives will be evaluated based on four general corrective action standards and five remedy selection decision factors. All corrective action alternatives must meet the general standards to be selected for evaluation using the remedy selection decision factors.

The general corrective action standards are:

- Protection of human health and the environment

- Compliance with media cleanup standards

- Control of the source(s) of the release

- Compliance with applicable federal, state, and local standards for waste management

The remedy selection decision factors are:

- Short-term reliability and effectiveness

- Reduction of toxicity, mobility, and/or volume

- Long-term reliability and effectiveness

- Feasibility

- Cost

\subsubsection{Corrective Action Standards}

The following text describes the corrective action standards used to evaluate the corrective action alternatives. 


\section{Protection of Human Health and the Environment}

Protection of human health and the environment is a general mandate of the RCRA statute (EPA, 1994). This mandate requires that the corrective action include any protective measures that are needed. These measures may or may not be directly related to media cleanup, source control, or management of wastes. The corrective action alternatives are evaluated for the ability to meet corrective action objectives as defined in Section 3.1.

\section{Compliance with Media Cleanup Standards}

Each corrective action alternative must have the ability to meet the proposed media cleanup standards as set forth in applicable regulations (NAC 444 [NAC, 1996a] and NAC 445A.2272 [NAC, 1996b]). This regulation prescribes an appropriate level of concentration that is based on the protection of public health and safety and the environment. The appropriate level must be based on the Integrated Risk Information System. For this CAU, the EPA's Region IX Preliminary Remediation Goals, which are derived from the Integrated Risk Information System, are the basis for establishing the PALs (EPA, 1998). Preliminary action levels were not exceeded; therefore, only media cleanup standards related to NAC 444 apply (NAC, 1996a).

\section{Control of the Source(s) of the Release}

An objective of corrective action remedy is to stop further environmental degradation by controlling or eliminating additional releases that may pose a threat to human health and the environment. Unless source control measures are taken, efforts to clean up releases may be ineffective or, at best, will essentially involve a perpetual cleanup. Therefore, each corrective action alternative must use an effective source control program to ensure the long-term effectiveness and protectiveness of the corrective action.

\section{Compliance with Applicable Federal, State, and Local Standards for Waste Management}

During implementation of any corrective action alternative, all waste management activities must be conducted in accordance with applicable state and federal regulations (e.g., Nevada Revised Statutes [NRS] 459.400 - 459.600 [NRS, 1995]; RCRA 40 Code of Federal Regulations [CFR] 261 - 281 [CFR, 1996]; 40 CFR 268, "Land Disposal Restrictions," NAC 444, "Solid Waste Disposal" [NAC, 1996a]; and NAC 459.9974, "Disposal and Evaluation of Contaminated Soil" 
[NAC, 1996c]). The requirements for management of the waste, if any, derived from the corrective action will be determined based on applicable state and federal regulations, field observations, process knowledge, characterization data, and data collected and analyzed during corrective action implementation. Administrative controls (e.g., decontamination procedures and corrective action strategies) will minimize waste generated during site corrective action activities. Decontamination activities will be performed in accordance with approved procedures as specified in the NDEP-approved TTR work plan (DOE/NV, 1996a) and will be designated according to the contaminants present at the site.

\subsubsection{Remedy Selection Decision Factors}

The following paragraphs describe the remedy selection decision factors used to evaluate the corrective action alternatives.

\section{Short-Term Reliability and Effectiveness}

Each corrective action alternative must be evaluated with respect to its effects on human health and the environment during the construction and implementation phase of the corrective action. The following factors will be addressed for each alternative:

- Protection of the community from potential risks associated with implementation such as fugitive dusts, transportation of hazardous materials, and explosion

- Protection of workers during construction and implementation

- Environmental impacts that may result from construction and implementation

- The amount of time until the corrective action objectives are achieved

\section{Reduction of Toxicity, Mobility, and/or Volume}

Each corrective action alternative must be evaluated for its ability to reduce the toxicity, mobility, and/or volume of the contaminated media. Reduction in toxicity, mobility, and/or volume refers to changes in one or more characteristics of the contaminated media by the use of corrective measures that decrease the inherent threats associated with that media. 


\section{Long-Term Reliability and Effectiveness}

Each corrective action alternative must be evaluated in terms of risk remaining at the CAU after the corrective action alternative has been implemented. The primary focus of this evaluation is the extent and effectiveness of the controls that may be required to manage risk posed by treatment residuals and/or untreated wastes.

\section{Feasibility}

The feasibility criterion addresses the technical and administrative feasibility of implementing a corrective action alternative and the availability of various services and materials needed during implementation. Each corrective action alternative must be evaluated for the following criteria:

- Construction and Operation. This refers to the feasibility of implementing a corrective action alternative given the existing set of waste and site-specific conditions.

- Administrative Feasibility. This refers to the administrative activities needed to implement the corrective action alternative (e.g., permits, public acceptance, rights of way, off-site approval).

- Availability of Services and Materials. This refers to the availability of adequate off-site and on-site treatment, storage capacity, disposal services, essential technical services and materials, and prospective technologies for each corrective action alternative.

\section{Cost}

Costs for each alternative are estimated for comparison purposes only. The cost estimate for each corrective action alternative includes both capital and operation and maintenance costs, as applicable. The following is a brief description of each component.

- Capital Costs: These costs include both direct and indirect costs. Direct costs may consist of materials, labor, mobilization, demobilization, site preparation, construction materials, equipment purchase and rental, sampling and analysis, waste disposal, and health and safety measures. Indirect costs include such items as engineering design, permits and/or fees, start-up costs, and any contingency allowances.

- Operation and Maintenance: These costs include labor, training, sampling and analysis, maintenance materials, utilities, and health and safety measures.

Cost estimate summaries for this CADD are provided in Appendix C. 


\subsection{Development of Corrective Action Alternatives}

This section identifies and briefly describes the viable corrective action technologies and the corrective action alternatives considered for the affected media. Based on the review of existing data, future land use, and current operations at the Nellis Air Force Range, the following alternatives have been developed for consideration at DTRSA:

- Alternative 1 - No Further Action

- Alternative 2 - Clean Closure by Excavation and Disposal

Other alternatives, such as engineering or institutional controls, were considered. However, engineering or institutional controls were deemed not to be protective due to the possibility of inadvertent bombing and potential future uses of the site.

There were no COCs identified during the investigation of CAU 486; therefore, analysis of NAC 445A.227 (2) (a-k) criteria (NAC, 1996b) is not required and groundwater monitoring is not considered in the remainder of the document.

\subsubsection{Alternative 1 - No Further Action}

Under the No Further Action Alternative, no corrective action activities will be implemented. This alternative is used as a starting point to establish a baseline for comparison with the other corrective action alternatives. This alternative does not meet the corrective action objectives because no actions are taken to prevent human contact with the contaminated man-made debris.

\subsubsection{Alternative 2 - Clean Closure by Excavation and Disposal}

Alternative 2 consists of removing the man-made debris within the burial pit (an assumed area of approximately 750 square feet $\left[\mathrm{ft}^{2}\right]$ ) (see Figure A.2-3 in Appendix A) to a depth of about 5 feet (ft). Uncontaminated man-made debris will be separated for disposal as solid waste. Contaminated material would be disposed of at an approved disposal facility; clean soil removed during excavation would be used for backfill. Excavated areas will be backfilled with uncontaminated soils and recontoured to eliminate topographic depressions and allow runoff. Excavation would be used to remove clean borrow soil from a proximal location for placement in any remaining void. 


\subsection{Evaluation and Comparison of Alternatives}

The general corrective action standards and remedy selection decision factors described in Section 3.2 were used to conduct a detailed evaluation of each corrective action alternative. A comparative evaluation of the corrective action alternatives was performed using the evaluation criteria. In this way, the advantages and disadvantages of each alternative are assessed to select a preferred alternative for CAU 486. Table 3-1 presents a summary of the detailed analysis of the alternatives. Table 3-2 presents the comparative analysis of alternatives. A summary of costs for the two alternatives is provided in Appendix C. 
Table 3-1

Detailed Evaluation of Alternatives

\begin{tabular}{|c|c|c|}
\hline Evaluation Criteria & $\begin{array}{l}\text { Alternative } 1 \\
\text { No Further Action }\end{array}$ & $\begin{array}{c}\text { Alternative } 2 \\
\text { Clean Closure by Excavation and } \\
\text { Disposal }\end{array}$ \\
\hline \multicolumn{3}{|c|}{ Closure Standards } \\
\hline $\begin{array}{l}\text { Protection of Human Health and } \\
\text { the Environment }\end{array}$ & $\begin{array}{l}\text { - } \quad \text { COPCs below regulatory action levels. } \\
\text { Does not meet corrective action objective } \\
\text { of preventing inadvertent intrusion into } \\
\text { contaminated man-made debris or spread } \\
\text { due to erosion or inadvertent bombing. } \\
\text { No worker exposure associated with } \\
\text { implementation. } \\
\text { Low risk to public because of remote } \\
\text { location and controlled access to Nellis Air } \\
\text { Force Range. }\end{array}$ & $\begin{array}{l}\text { - } \text { Meets corrective action objectives. } \\
\text { Prevents exposure by inadvertent } \\
\text { intrusion into debris. } \\
\text { Limited risk to workers during } \\
\text { implementation because of excavation } \\
\text { requirement and exposure to } \\
\text { contaminated man-made debris. } \\
\text { - Low risk to public because of remote } \\
\text { location and controlled access to Nellis Air } \\
\text { Force Range. }\end{array}$ \\
\hline $\begin{array}{l}\text { Compliance with Media } \\
\text { Cleanup Standards }\end{array}$ & $\begin{array}{l}\text { Does not currently comply with media } \\
\text { cleanup standards. }\end{array}$ & $\begin{array}{l}\text { Does comply with media cleanup } \\
\text { standards. }\end{array}$ \\
\hline $\begin{array}{l}\text { Control of the Source(s) of } \\
\text { Release }\end{array}$ & $\begin{array}{l}\text { - The contaminated man-made debris will } \\
\text { remain. }\end{array}$ & $\begin{array}{l}\text { - The contaminated man-made debris will } \\
\text { be removed. }\end{array}$ \\
\hline $\begin{array}{l}\text { Compliance with Applicable } \\
\text { Federal, State, and Local } \\
\text { Standards for Waste } \\
\text { Management }\end{array}$ & - No waste generated. & $\begin{array}{l}\text { Waste will be generated from removal of } \\
\text { uncontaminated and contaminated } \\
\text { man-made debris. } \\
\text { Waste will be handled and disposed of per } \\
\text { applicable standards. }\end{array}$ \\
\hline \multicolumn{3}{|c|}{ Remedy Selection Decision Factors } \\
\hline $\begin{array}{l}\text { Short-Term Reliability and } \\
\text { Effectiveness }\end{array}$ & $\begin{array}{l}\text { - No risk to workers. } \\
\text { Public protected by remote location and } \\
\text { TTR site access controls. }\end{array}$ & $\begin{array}{l}\text { Moderate risk to workers associated with } \\
\text { excavation and disposal activities and } \\
\text { exposure to contaminated man-made } \\
\text { debris. } \\
\text { Public protected by remote location and } \\
\text { TTR site access controls. }\end{array}$ \\
\hline $\begin{array}{l}\text { Reduction of Toxicity, Mobility, } \\
\text { and/or Volume }\end{array}$ & $\begin{array}{l}\text { - } \quad \text { The debris will remain. } \\
\text { Possible exposure from inadvertent } \\
\text { bombing or erosion. }\end{array}$ & $\begin{array}{l}\text { - The debris will be removed and disposed } \\
\text { in a controlled landfill. } \\
\text { The amount, location, and characteristics } \\
\text { of the waste will be known. }\end{array}$ \\
\hline $\begin{array}{l}\text { Long-Term Reliability and } \\
\text { Effectiveness }\end{array}$ & $\begin{array}{l}\text { Possible exposure from inadvertent } \\
\text { bombing or erosion. }\end{array}$ & $\begin{array}{l}\text { The status of the debris will be known. } \\
\text { - All debris will be removed for proper } \\
\text { disposal. } \\
\text { Eliminates possible inadvertent intrusion } \\
\text { from bombing or erosion. }\end{array}$ \\
\hline Feasibility & - $\quad$ Easy to implement. & $\begin{array}{ll} & \text { Easy to implement. } \\
\text { - } & \text { No utilities or surface structures to hinder } \\
\text { excavation activities. } \\
\text { - Shallow depth of removal area would limit } \\
\text { requirements for shoring. }\end{array}$ \\
\hline Cost & $\$ 0$ & $\$ 157,471$ \\
\hline
\end{tabular}


Table 3-2

Comparative Evaluation of Alternatives

\begin{tabular}{|c|c|}
\hline Evaluation Criteria & Comparative Evaluation \\
\hline \multicolumn{2}{|r|}{ Closure Standards } \\
\hline $\begin{array}{l}\text { Protection of Human Health } \\
\text { Environment }\end{array}$ & $\begin{array}{l}\text { Alternative } 2 \text { will meet corrective action objectives; Alternative } 1 \text { will not. } \\
\text { Worker exposure to risks increases from no risk associated with Alternative } 1 \text {, } \\
\text { to limited risk associated with Alternative } 2 \text {. No evaluation of NAC } 445 A .227 \\
\text { (2) (a-k) (Section } 3.3 ; \text { NAC, } 1996 \mathrm{~b}) \text { required. The relatively low levels of alpha } \\
\text { and gamma field screening readings and low mobility of the contamination } \\
\text { present minimal risk under each of the alternatives. }\end{array}$ \\
\hline $\begin{array}{l}\text { Compliance with Media Cleanup } \\
\text { Standards }\end{array}$ & Alternative 2 will comply with media cleanup standards. Alternative 1 will not. \\
\hline $\begin{array}{l}\text { Control of the Source(s) of the } \\
\text { Release }\end{array}$ & $\begin{array}{l}\text { Alternative } 2 \text { will have some potential for release of contaminated man-made } \\
\text { debris during removal and subsequent disposal. }\end{array}$ \\
\hline $\begin{array}{l}\text { Compliance with Applicable } \\
\text { Federal, State, and Local } \\
\text { Standards for Waste Management }\end{array}$ & $\begin{array}{l}\text { Alternative } 1 \text { will not generate any waste. Alternative } 2 \text { will generate waste } \\
\text { associated with removal and disposal of the debris. All waste will be managed } \\
\text { and disposed per applicable standards. }\end{array}$ \\
\hline \multicolumn{2}{|r|}{ Remedy Selection Decision Factors } \\
\hline $\begin{array}{l}\text { Short-Term Reliability and } \\
\text { Effectiveness }\end{array}$ & $\begin{array}{l}\text { Worker exposure to risks will increase from no risk associated with } \\
\text { Alternative } 1 \text { to moderate risk associated with Alternative } 2 \text {. }\end{array}$ \\
\hline $\begin{array}{l}\text { Reduction of Toxicity, Mobility, } \\
\text { and/or Volume }\end{array}$ & $\begin{array}{l}\text { Alternative } 2 \text { will result in immediate reduction associated with removal of the } \\
\text { debris. }\end{array}$ \\
\hline $\begin{array}{l}\text { Long-Term Reliability and } \\
\text { Effectiveness }\end{array}$ & $\begin{array}{l}\text { Alternative } 2 \text { will result in clean closure with no long-term monitoring } \\
\text { requirements. }\end{array}$ \\
\hline Feasibility & Alternative 2 will be feasible. \\
\hline Cost & $\begin{array}{l}\text { The cost for Alternative } 1 \text { will be } \$ 0 \text {. The cost for Alternative } 2 \text { will be } \$ 157,471 \\
\text { for removal and disposal of contaminated man-made debris. }\end{array}$ \\
\hline
\end{tabular}




\subsection{Recommended Alternative}

Based on the results of the detailed and comparative analysis of the potential corrective action alternatives presented in this document, the preferred corrective action alternative selected for implementation at CAU 486 is Alternative 2, Clean Closure by Excavation and Disposal.

Alternative 2 was chosen for the following reasons:

- There were no COCs identified during the investigation. Radiological field screening did detect elevated gamma and removable alpha radiation on man-made debris buried at the site, but not on associated soils.

- Short-term risks to workers are minimal under this alternative.

- Long-term risks are eliminated by removing the contaminated debris for disposal.

- Only minimal wastes are generated. All waste will be handled and disposed of in accordance with applicable standards.

- It is easy to implement using existing resources and technologies with minimal disturbance to surrounding areas.

- It provides the most cost-effective method for achieving protection and for meeting closure requirements.

The preferred corrective action alternative was evaluated on its technical merits, focusing on performance, reliability, feasibility, and safety. During corrective action implementation, this alternative will present minimal potential threat to site workers. However, appropriate health and safety procedures will be developed and implemented. The alternative was judged to meet all requirements for the technical components evaluated. The alternative meets all applicable state and federal regulations for closure of the site and will eliminate potential future exposure pathways to buried contaminated man-made debris.

There will be no restrictions for future use of any land related to this CAU, as described by this CADD, as approved by the State of Nevada, and identified in the CAU Closure Report or other CAU documentation. 


\subsection{References}

Burnett, W.D., H.L. Rarrick, and G.E. Tucker, Jr. 1964. Health Physics Aspects of Operation Roller Coaster, Report \#SC-4973 (RR). Albuquerque, NM: Sandia National Laboratories.

CFR, see Code of Federal Regulations.

Code of Federal Regulations. 1996. Title 40 CFR Parts 260 - 281, "RCRA Regulations."

Washington, DC: U.S. Government Printing Office.

DOE/NV, see U.S. Department of Energy, Nevada Operations Office.

EPA, see U.S. Environmental Protection Agency.

FFACO, see Federal Facility Agreement and Consent Order.

Federal Facility Agreement and Consent Order. 1996 (as amended). Agreed to by the Nevada Division of Environmental Protection, the U.S. Department of Energy, and the U.S. Department of Defense.

NAC, see Nevada Administrative Code.

Nevada Administrative Code. 1996a. NAC 444, "Solid Waste Disposal." Carson City, NV.

Nevada Administrative Code. 1996b. NAC 445A, "Water Pollution Control." Carson City, NV.

Nevada Administrative Code. 1996c. NAC 459, "Disposal and Evaluation of Contaminated Soil." Carson City, NV.

NRS, see Nevada Revised Statutes.

Nevada Revised Statutes. 1995. NRS 459.400-459-600, “Disposal of Hazardous Waste." Carson City, NV.

Shacklette, H.T., and J.G. Boerngen. 1984. Element Concentrations in Soils and Other Surficial Materials of the Conterminous United States, U.S. Geological Survey Professional Paper 1270. Washington, DC: U.S. Government Printing Office.

U.S. Department of Energy, Nevada Operations Office. 1994. Project Management Plan, Rev. 0. Las Vegas, NV.

U.S. Department of Energy, Nevada Operations Office. 1996a. Corrective Action Unit Work Plan for the Tonopah Test Range, DOE/NV--443. Las Vegas, NV. 
U.S. Department of Energy, Nevada Operations Office. 1996b. Industrial Sites Quality Assurance Project Plan, DOE/NV--372. Las Vegas, NV: IT Corporation.

U.S. Department of Energy, Nevada Operations Office. 1998. Corrective Action Investigation Plan for Corrective Action Unit 486: Double Tracks RADSAFE Area, Nellis Air Force Range, Nevada, DOE/NV--523, Rev. 0. Las Vegas, NV: IT Corporation.

U.S. Environmental Protection Agency. 1991. Guidance on Resource Conservation and Recovery Act (RCRA) Corrective Action Decision Documents, EPA/540/G-91/011. Washington, DC: Office of Research and Development.

U.S. Environmental Protection Agency. 1994. Final RCRA Corrective Action Plan, EPA/520-R-94-004. Washington, DC: Office of Solid Waste and Emergency Response.

U.S. Environmental Protection Agency. 1998. Memo from S. J. Smucker, regarding an update to the Region 9 Preliminary Remediation Goals (PRGs) Table, 1 August. San Francisco, CA. 


\section{Appendix A}

\section{Corrective Action Investigation Report for CAU 486: Double Tracks RADSAFE Area, Nellis Air Force Range, Nevada}




\section{A.1.0 Introduction}

The report contained in this presents the investigation activities and analytical results from the corrective action investigation conducted at the DTRSA, CAU 486. The CAU consists of CAS Number 71-23-001-71DT. The corrective action investigation was conducted in accordance with the requirements set forth in the Corrective Action Investigation Plan for Corrective Action Unit 486: Double Tracks RADSAFE Area, Nellis Air Force Range, Nevada (DOE/NV, 1998) as developed under the Federal Facility Agreement and Consent Order (FFACO, 1996).

The DTRSA was investigated because process knowledge indicated that potentially radioactively contaminated liquids and/or materials were disposed of at the site. The DTRSA was used during May 1963 to decontaminate vehicles, equipment, personnel, and animals from the Double Tracks test. The DTRSA was also identified as a potential location for the disposal of radioactively contaminated materials from the Double Tracks test. Additional information relating to the site history, planning, and scope of the investigation is presented in the CAIP (DOE/NV, 1998) and will not be repeated in this report.

\section{A.1.1 Project Objectives}

The following were the primary objectives for this project:

- Identify and verify the boundaries of a decontamination facility and an animal burial pit within the DTRSA.

- Identify the presence and the vertical and lateral extent of COPCs, specifically radionuclides (e.g., plutonium, depleted uranium).

- Provide sufficient information and data to develop appropriate corrective action alternatives for the DTRSA.

The selection of drilling locations for soil sample collection were selected based on site conditions and the strategy devised in the DQO process. 


\section{A.1.2 Report Content}

This report contains sufficient information and data to support the selection of a preferred corrective action alternative in the CADD. The contents of this report are as follows:

- Section A.1.0 describes the investigation background, objectives, and the report content.

- Section A.2.0 provides information regarding the field activities and sampling method.

- Section A.3.0 summarizes the results of the laboratory analysis from the investigation sampling.

- Section A.4.0 discusses the quality assurance (QA) and QC procedures that were followed and the results of the QA and QC activities.

- Section A.5.0 is a summary of the investigation results for CAU 486 DTRSA.

- Section A.6.0 cites the references.

- Appendix B presents the soil boring logs and information pertinent to the corrective action decision process.

The complete field documentation and laboratory data, including Field Activity Daily Logs, Sample Collection Logs, Analysis Request/Chain-of-Custody Forms, soil sample descriptions, laboratory certificates of analyses, analytical results, and surveillance results are not contained in this report. These documents are retained in project files as both hard copy files and electronic media. 


\section{A.2.0 Field Investigation and Sampling Activities}

The field investigation and sampling activities were conducted in two separate phases between November 16 through December 4, 1998. Phase I was the identification of boundaries for both the decontamination facility and the animal burial pit. Phase II was the subsurface investigation consisting of soil sample collection. The following is a brief summary of the corrective action investigation activities as performed:

- Excavated one background trench, four identification trenches, and nine step-out trenches on the south side of the DTRSA.

- Excavated four identification trenches in Area 2 and six identification trenches in Area 6 on the north side of the DTRSA.

- Established radiological field-screening levels.

- Drilled two vertical background boreholes, collected samples for laboratory analysis, and logged soil cuttings to assist with site geology assessments.

- Drilled eight vertical investigation boreholes, conducted field screening for radiological constituents and VOCs, collected environmental samples for laboratory analysis, collected soil samples for geotechnical analysis, and logged soil cuttings to assess site geology.

The subsurface investigation and sampling program was managed in accordance with the requirements set forth in the CAIP (DOE/NV, 1998). The field activities were performed in accordance with an approved Site-Specific Health and Safety Plan (IT, 1998b). The samples were collected by following approved sampling plans, decontamination, chain of custody, shipping, and radiation screening protocols and procedures as indicated in the CAIP (DOE/NV, 1998) and documented using field activity daily logs and sample collection logs. Quality control samples (e.g., field blanks, equipment rinsate blanks, trip blanks, and sample duplicates) were collected as required by the Industrial Sites Quality Assurance Project Plan (QAPP) (DOE/NV, 1996b) and approved procedures. During field activities, waste minimization practices were followed according to approved procedures, including segregation of the waste by waste stream. 


\section{A.2.1 Site Description and Conditions}

The DTRSA is located in the Nellis Air Force Range 71 North approximately 5 mi west of the TTR at the intersection of the Cactus Spring and Double Tracks Control Point roads. The site is located on an alluvial fan surface with relatively flat ground and sparse vegetation. The site is divided into two halves (north and south) separated by the Cactus Spring Road. The only physical evidence of past occupation of the site is the vegetation change in previously disturbed areas and partially exposed plywood and metal posts in Area 2 on the north side of the site. The purpose of this investigation was to identify and verify the locations of the decontamination facility and the animal burial pit, identify the presence and nature of COPCs, and determine the vertical and lateral extent of those COPCs. Excavation activities performed during the first phase of the investigation uncovered both the decontamination facility and animal burial pit. In addition, a third area of concern was identified as a loading/unloading area. The following paragraphs describe each area in greater detail. Figure A.2-1 shows the three areas of concern and their approximate boundaries as determined by Phase I excavation activities.

Phase I excavation activities in the southern half of the DTRSA resulted in the identification of the decontamination facility (vehicle decontamination $\mathrm{pad} / \mathrm{sump}$ trench). The location, approximately $80 \mathrm{ft}$ south of Cactus Spring Road, was identified by a combination of subsurface geologic changes and radiation field-screening results above FSLs. The dimensions for length of the facility vary from 45 to $60 \mathrm{ft}$ with a width of $45 \mathrm{ft}$. The depth, as determined by both excavation and drilling activities, varies between 1 and $4 \mathrm{ft}$. The decontamination facility is comprised mostly of 2- to 7-inch (in.) diameter gravel and cobbles.

Phase I excavation activities in Area 2, resulted in the identification of a 4-ft deep trench with a length of $40 \mathrm{ft}$ and width of $18 \mathrm{ft}$. The trench is located north of the partially exposed plywood and metal posts which are now believed to have been shoring for the southern wall of the trench. Area 2 is believed to represent a loading/unloading area for the animal trailers so that personnel had easier access to the animals.

Phase I excavation activities at the Area 6 buried anomaly resulted in the identification of a burial pit/trench with a length of $75 \mathrm{ft}$ and width of $21 \mathrm{ft}$. The depth varies from approximately 1 to $5 \mathrm{ft}$ 


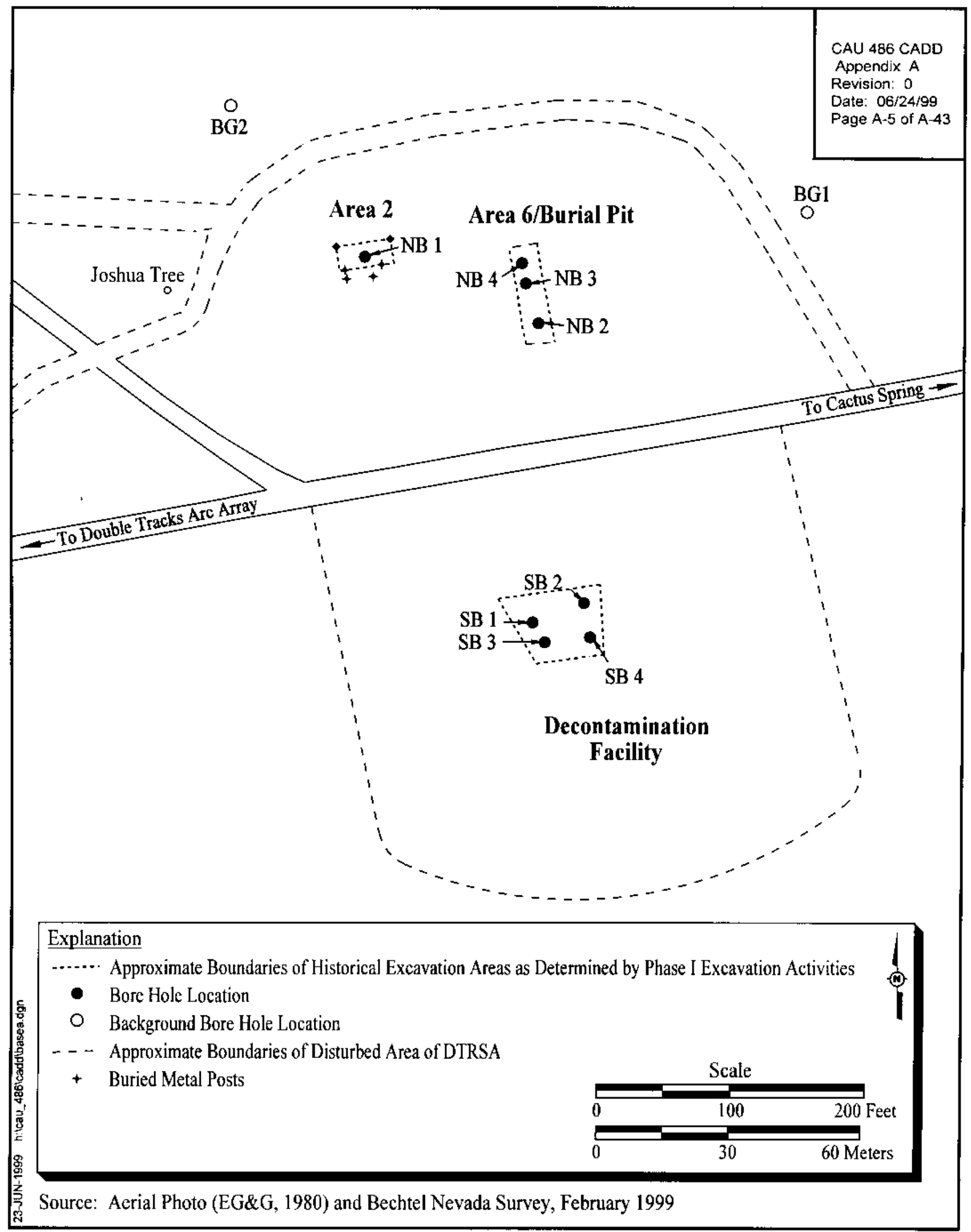

Figure A.2-1

Investigation Locations for DTRSA 
with the deepest point in the center of the trench. This burial pit was the only area investigated that contained debris associated with Double Tracks activities, some of which had radiological field-screening results above FSLs.

\section{A.2.2 Investigation Logistics}

This section describes the sample collection and investigation activities for each of the areas of concern at the DTRSA.

\section{A.2.2.1 Excavation}

Fifteen linear trenches (including one background trench) plus nine step-out trenches were excavated during Phase I activities to identify and delineate the boundaries of the areas of concern (see Figures A.2-2 and A.2-3). A backhoe was used to excavate trenches as described in the CAIP (DOE/NV, 1998) and all spoils were backfilled to the location of removal. The linear length of each trench varied between 10 and $80 \mathrm{ft}$. Excavation reached a maximum depth of $5 \mathrm{ft}$.

Prior to trenching within the area of concern, one north-south trending background trench was excavated in an undisturbed area to identify the native subsurface geology. Subsurface geology was the primary identification tool used in determining boundaries of each area of concern. Field screening for radiation and VOCs was conducted during the excavations and is discussed in subsequent subsections. No environmental samples were collected during Phase I. The locations of all excavated trenches are shown in Figure A.2-2 (south side) and Figure A.2-3 (north side).

Due to the potential for buried ordnance at the areas of concern on the north side of the road, unexploded ordnance (UXO) specialists were present to assist with excavation activities. Prior to the start of excavation activities and to the removal of each lift of soil, UXO personnel surveyed the soil using magnetometers. This was done until the threat of potential UXO no longer existed, as deemed by the UXO specialist.

\section{A.2.2.2 Drilling}

Using the rotary sonic ("sonic") drilling method, two background and eight investigation borings were drilled for the DTRSA investigation during Phase II activities (see Figure A.2-1). All borings 


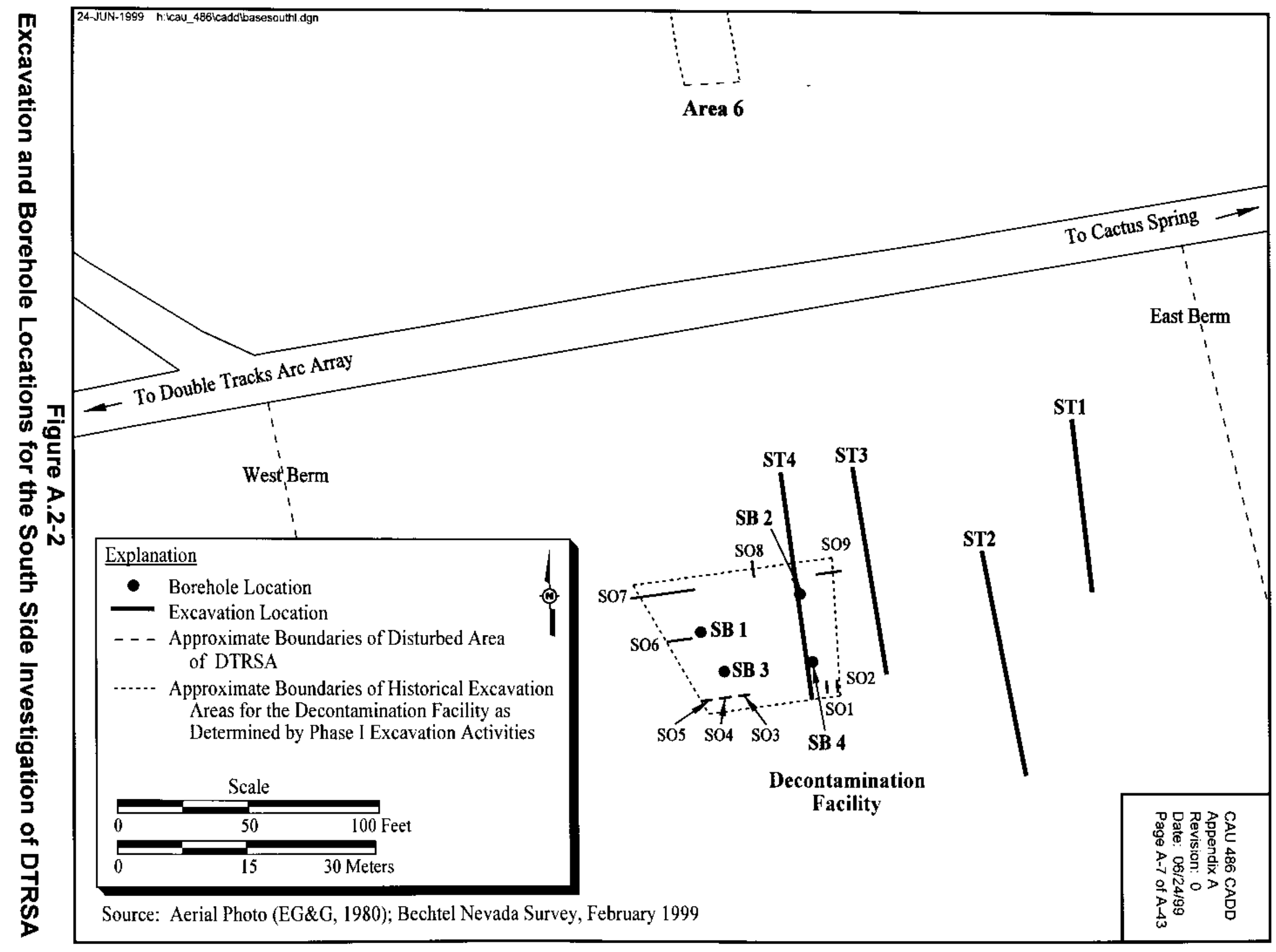


were drilled vertically to a maximum depth of $20 \mathrm{ft}$ below ground surface (bgs). The two background boreholes were drilled upgradient in undisturbed areas north of the DTRSA. These two boreholes were drilled first and native soil was encountered throughout the borehole, as expected. Field screening was performed and samples were sent to the laboratory for analysis from the 1, 5, 10,15 , and $20 \mathrm{ft}$ depths.

A total of eight investigation boreholes were drilled inside the areas of concern to identify the presence and delineate the lateral and vertical extent of COPCs. The sonic drilling method produced continuous soil cores that were used for detailed field observations, visual classification of soils, field screening, and sampling of the subsurface soil at specified depth intervals. Soil cuttings were delivered to the field geologist and sampling team in labeled polyurethane bags in approximately 2.5 -ft long sections. Field screening for radiation and VOCs (headspace screening) was used to guide the lateral and vertical extent of the investigation in the field. Sampling intervals and sample submission frequency were based on minimum requirements established during the DQO process, field-screening results, and the discretion of the Site Supervisor.

The sonic drilling method uses vibration and rotation of the drill string to advance a core barrel and an outer casing. The casing is used to stabilize the hole and also minimizes potential cross contamination produced by soil from shallower levels falling down the hole (sloughing) as the core barrel is removed for cuttings extrusion. After the bit at the end of the core barrel reaches the specified depth, the core barrel is withdrawn from the borehole and the contents are extruded into polyurethane bags. While the sonic drilling method produces some heat from friction, the samples were hand carried to the sampling table and were not observed to be hot on any occasion. The relatively large core barrel diameter and soil type (i.e., loose soils) may have also reduced the effect of friction on the samples. For this project, 6-in. diameter core barrels and 8-in. diameter casing were advanced. The casing was removed, and the boreholes were filled with grout to complete each boring.

\section{A.2.2.3 Southern Half of DTRSA}

Excavation in the southern half of the DTRSA consisted of four north-south trending trenches and nine north-south and east-west trending step-out trenches (Figure A.2-2). Three identification 
trenches were excavated before locating evidence of the decontamination facility in trench number four (South Trench [ST] 4). Subsurface geology in ST1 through ST3 consisted of native soil profiles as observed within the background trench. The first $30 \mathrm{ft}$ of ST4 consisted of native soil. Evidence of the decontamination facility, in the form of gravel fill material, occurred at approximately $35 \mathrm{ft}$ from the north end of ST4 and continued for an additional $45 \mathrm{ft}$. Elevated gamma counts above the daily FSL of 5,852 counts per minute (cpm) were detected in the range of 6,730 to $15,900 \mathrm{cpm}$ on excavated gravel between 55 and $60 \mathrm{ft}$ from the north end of ST4. Swipe surveys were taken on the same gravel and no removable contamination was detected. Beta and alpha field screening results were below FSLs. Nine step-out trenches, ranging in length from 3 to $13 \mathrm{ft}$, were excavated to delineate the remaining boundaries of the decontamination facility. The results indicate length dimensions (east-west) of $45 \mathrm{ft}$ for the southern boundary and $60 \mathrm{ft}$ for the northern boundary. The width (north-south) of the decontamination facility was determined to be approximately $45 \mathrm{ft}$. No man-made debris was encountered in any of the trenches.

Four borings (South Boring [SB]-1 through SB4) were drilled within the decontamination facility (Figure A.2-2). Gravel fill material was encountered in SB1 to a depth of 3.5-ft bgs and native soil was penetrated below this point to $20 \mathrm{ft}$. An increased sampling frequency for isotopic plutonium and uranium was conducted beginning at the 4-ft interval. Large subangular boulder/cobble/gravel was encountered in SB2 to a depth of 4-ft bgs and native soil was penetrated below this point to $20 \mathrm{ft}$. The increased sampling frequency for isotopic plutonium and uranium was conducted beginning at the 5-ft interval. SB2 was positioned adjacent to the ST4 location where elevated gamma counts were detected during excavation; however, both field-screening results and analytical results were below FSLs and background levels, respectively, in the boring. Gravel was encountered in SB3 to a depth of 2.5-ft bgs with the native soil interface below this point. The increased sampling frequency for isotopic plutonium and uranium was conducted beginning at the 3-ft interval. Gravel was encountered in SB4 to a depth of 3-ft bgs with the native soil interface below this point. The increased sampling frequency for isotopic plutonium and uranium was conducted beginning at the 4-ft interval. No debris was encountered in any of the borings. There were no elevated radiological or VOC field-screening results for SB1 through SB4 and no step-out borings were drilled. Nondetect (i.e., field-screening results below FSLs) samples were also collected at the 15-ft and 20-ft intervals from each boring. Table A.3-1 lists all the sample numbers 
and sample depth collected and submitted for analysis. The soil boring logs located in Appendix B provide detailed descriptions of the soil borings along with the collected sample intervals.

\section{A.2.2.4 Area 2 Investigation}

Excavation in Area 2 consisted of four north-south trending identification trenches numbered NT1 through NT4 (Figure A.2-3). The partially exposed metal posts were not removed from the subsurface, but were verified by the UXO specialist to be the only metal present with no indication of buried ordnance. Based on subsurface geological conditions, the area of concern is a 4-ft deep by 41-ft long by 18-ft wide trench that resembles a loading/unloading area perhaps used for the animal trailers during the Double Tracks test. No debris other than the partially exposed plywood and metal posts was encountered and no soil staining was observed. Field-screening results for radiation and VOCs were below the established FSLs.

One borehole, NB1, was drilled in the center of Area 2 for soil sample collection (Figure A.2-3). Fill material consisting of well-graded gravelly sand was encountered to a depth of $4 \mathrm{ft}$. Native soil was penetrated below this point to a total depth of $20 \mathrm{ft}$. An increased sampling frequency for isotopic plutonium and uranium was conducted beginning at the 5-ft interval. An additional sample for a full-suite of analyses was collected at the 5-ft interval. Nondetect samples were collected at the 15-ft and 20-ft intervals. See Table A.3-1 and Appendix B for details on sample numbers and soil descriptions. Step-out borings were not drilled. There were no elevated radiological or VOC field-screening results above the established FSLs for NB1.

\section{A.2.2.5 Area 6 Investigation}

Excavation in Area 6 consisted of six east-west trending identification trenches numbered 6NT1 through 6NT6 (Figure A.2-3). Excavation began at the location of the strongest metallic reading from the magnetometer and was designated trench 6NT1. This area corresponded to the anomaly discovered during a 1998 geophysical survey (SAIC, 1998). The metallic anomaly was determined to be debris associated with the burial pit, thus, ruling out the presence of ordnance. The debris consisted of chicken wire, pieces of lumber, and plastic bags filled with miscellaneous material including a "contaminated material" sticker and pieces of what appeared to be cloth. Figure A.2-4 shows photos taken of the debris at the bottom of the trench. Radiological field screening was 


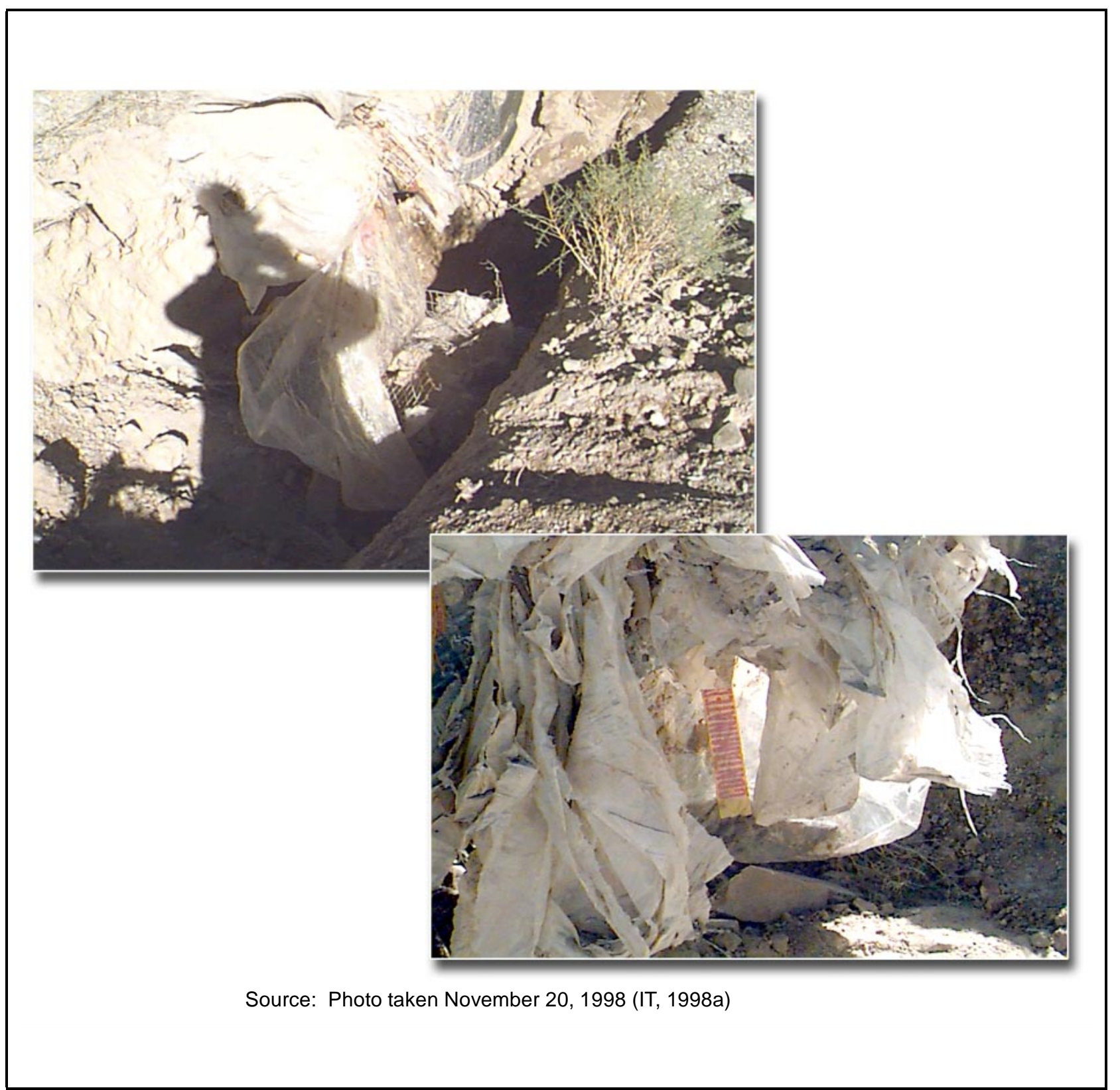

Figure A.2-4 Uncovered Debris in Trench 6NT1 
conducted directly on the bag containing the sticker and results showed an elevated gamma count of 15,600 cpm with the Field Instrument for the Detection of Low Energy Radiation (FIDLER) (the daily FSL for gamma was 5,645 cpm) and an elevated alpha count of 213 disintegrations per minute (dpm) per 100 square centimeters $\left(\mathrm{cm}^{2}\right)$ with the Electra ${ }^{\mathrm{TM}}$ (the daily FSL for alpha was $126 \mathrm{dpm} / 100 \mathrm{~cm}^{2}$ ). Beta counts were below FSLs. A swipe sample taken from within a plastic bag detected removable alpha of $283 \mathrm{dpm}$ per $100 \mathrm{~cm}^{2}$. Swipe samples and field screening results on the surrounding soil, fill material, and other debris (i.e., chicken wire and lumber) associated with 6NT1 were not elevated above the FSLs. The debris was left in place and covered with soil. The remaining excavations (6NT2 through 6NT6) were kept shallow (2.5 to $3 \mathrm{ft}$ ) within the gravel fill material to eliminate the potential for exposing buried debris. Observations on the subsurface geologic conditions (i.e., gravel fill) indicate the burial pit trench is about $21 \mathrm{ft}$ wide and 73 to $75 \mathrm{ft}$ long.

Three boreholes, NB2 through NB4, were drilled in Area 6 within the burial trench (Figure A.2-3). NB4 and NB2 were drilled north and south, respectively, of the contaminated debris uncovered in the Phase I trenching. NB3 was drilled adjacent to, but not through, the contaminated debris uncovered during Phase I activities. Fill material consisting of gravel and pea-size gravel was encountered in NB2 to a depth of 5-ft bgs, with native soil in the remainder of the boring. An increased sampling frequency for isotopic plutonium and uranium was conducted beginning at the 5-ft interval. Debris (plastic, wood, and wire) was encountered in NB3 at the 4- to 5-ft depth interval within sandy-gravel fill material. Native soil was penetrated at 5-ft bgs for the remainder of the boring. An increased sampling frequency for isotopic plutonium and uranium was conducted beginning at the 5-ft interval. Fill material consisting of gravelly sand and a small amount of debris (wood and wire) was encountered in NB4 to a depth of 5-ft bgs. Native soil was penetrated below 5-ft bgs for the remainder of the boring. An increased sampling frequency for isotopic plutonium and uranium was conducted beginning at the 5-ft interval. Step-out borings were not drilled. There were no elevated radiological or VOC field-screening results above the established FSLs for NB2 through NB4. Nondetect samples were collected at the 15-ft and 20-ft intervals from each boring. Additional sample intervals were collected for full-suite analysis based on interface location and FSLs. See Table A.3-1 and Appendix B for details on sample numbers and soil descriptions. 


\section{A.2.3 Field Screening}

The FSL for VOC field-screening was determined to be 20 parts per million (ppm) or 2.5 times background, whichever was higher. The FSLs for radiation monitoring results at the DTRSA were established prior to the start of the field investigation. The FSLs were established as the average activity of 20 background samples plus two times the standard deviation of the average activity of these 20 background samples (DOE/NV, 1998). In addition, daily response checks for the FIDLER instrument were conducted on five of the original background samples. These bags were labelled Bag \#BK 2, 4, 10, 17 and 20; additionally, soil was collected from these bags and submitted for isotopic plutonium and uranium analysis. If the recalculated FSL, based on these five samples, differed more than one standard deviation from the original FSL, then the FSL was changed for that day. Details on the procedure for establishing FSLs for alpha, beta, and gamma radiation are available in the CAIP (DOE/NV, 1998). Field-screening levels were established to guide the advancement of the borehole and to provide a basis for collecting unplanned environmental samples or drilling additional boreholes.

Field-screening methods were used to collect the semiquantitative radiological and VOC data required to guide the total drilling depth for each boring. Field screening was performed at $2.5-\mathrm{ft}$ intervals to a depth of $20 \mathrm{ft}$. The screening methods included:

- Radiological screening for alpha and beta radiation using an Electra ${ }^{\mathrm{TM}}$ instrument

- Radiological screening for gamma radiation using FIDLER instrument

- Headspace screening for VOCs using a photoionization detector (PID)

Headspace measurements were below $20 \mathrm{ppm}$ for all samples screened. Headspace measurements were not conducted in Area 2 and Area 6 because all nonessential personnel were not allowed in the exclusion zone during excavation activities due to the hazard potential of unearthing UXO. However, health and safety monitoring for VOCs in the breathing zone did not indicate elevated readings for these two areas. Headspace measurements were resumed in Area 2 and Area 6 during drilling activities.

Daily fluctuations in the gamma background measurements using the FIDLER resulted in gamma readings that were elevated above the daily FSL on three separate days during drilling. However, 
none of these readings were above the FSL established using the original 20 background samples. To confirm that the elevated gamma readings were due to instrument fluctuations caused by changing weather conditions throughout the day, supplemental field screening was conducted on the last $5 \mathrm{ft}$ of each boring. In addition, the daily FSL was established at nearly the same time interval. Field-screening results show that each boring was confirmed to be below the established FSL and that apparent elevated readings were indeed a result of instrument fluctuations.

\section{A.2.4 Sample Collection}

Sample collection followed the procedures specified in the CAIP (DOE/NV, 1998). Soil cores were moved from the boreholes to the sampling area in approximately 2.5 -ft lengths contained in polyurethane bags. The bags were split open and screened for alpha, beta, and gamma radiological contamination. The breathing zone was monitored for VOCs using a PID before and during sample collection. Samples were collected in appropriate containers, temporarily labeled, and sealed with custody tape. Soil for volatile analysis (VOCs, TPH-gasoline, and headspace field screening) were collected directly from the soil cores immediately after required radiation field screening and breathing zone monitoring for VOCs was conducted. Semivolatile organic compounds, RCRA metals, TPH-diesel/oil, and isotopic plutonium and uranium samples were collected from soil representative of the sampling interval which was homogenized in a stainless steel bowl. Waste characterization samples for plutonium and uranium, comprised of composite soil samples representing each drum of soil, were also collected for archival purposes but were not submitted for analysis.

After samples were identified as laboratory samples, labels printed with the sample number, sample collection date/time, chain-of-custody number, sampling team members, preservative, sample medium, and requested analysis were attached to each of the containers. Each sample container was then sealed with custody tape, wrapped in protective bubble wrap (if applicable), placed into a Ziploc $^{\mathrm{TM}}$ bag, and placed in an iced cooler with a trip blank (if applicable). Samples not submitted to the laboratory were containerized with other soil cuttings from the same boring after removing lids and defacing temporary sample labels. 
A total of four geotechnical samples were collected to assess geological and hydrological parameters of both fill material and native soil at the DTRSA. Each sample was collected in three 15-cm (6-in.) brass sleeves using a California Modified split-spoon sampler. Samples DTR00104 and DTR00107 were collected within fill material at borings SB3 and NB1, respectively. The other two samples (DTR00052 at boring NB4 and DTR00083 at boring SB2) were collected within native soil below the fill material/native soil interface. These samples were not submitted for analysis because the geotechnical data would not offer useful information based on the likely corrective action alternatives for DTRSA.

\section{A.2.5 Waste Management}

Investigation-derived waste (IDW) that came in contact with potentially contaminated media was segregated into the following four waste streams:

- Personal protective equipment and sampling equipment

- Decontamination rinsate

- Soil and debris incidental to sample collection (e.g., soil cuttings, discarded samples)

- $\quad$ Plastic or other material (e.g., decontamination pad, plastic sheeting placed under trenched spoils)

Potentially hazardous and/or radioactive waste generated during site operations was labeled as such and temporarily accumulated in a Hazardous Waste Accumulation Area (HWAA)/Radioactive Materials Area (RMA) located within the boundaries of the DTRSA investigation area. Information regarding each container of IDW was documented in a project-specific waste management logbook. As discussed in the CAIP, IDW generated at the DTRSA was transferred to a HWAA/RMA in Area 9 on the TTR at the conclusion of field activities.

\section{A.2.6 Geology}

Fill material encountered in each area investigated was typically comprised of either sandy gravels and/or poorly-graded gravel, cobble, and boulder mixtures overlying native soils. Native soil beneath fill material consists of well-graded, moderately consolidated alluvial sands with gravel, 
cobble, and boulder-sized volcanic detritus. Field descriptions were performed for each boring by the field geologist and recorded on Visual Classification of Soil Logs (Appendix B).

\section{A.2.7 Hydrology}

Depth to groundwater beneath the DTRSA is estimated at 820 to $886 \mathrm{ft}$ bgs (DOE/NV, 1996a). No saturated zones (e.g., perched water, contaminant saturation) were found in the subsurface at the DTRSA. The alluvial fan surface slopes to the southwest with surface drainage flowing in the same direction. Evidence of intermittent drainage exists within the DTRSA; therefore, flooding events have the potential to impact the site. 


\section{A.3.0 Investigation Results}

The analytical results of samples collected from the DTRSA CAU site investigation have been compiled and evaluated to determine the presence and/or extent of contamination. The analytical results are summarized in the following subsections. The complete laboratory result data packages are available in the project files.

During the Phase II (drilling) investigation activities, a total of 95 samples (73 soil and 22 liquid samples) were collected and submitted for laboratory analysis. A list of the samples collected and the parameters analyzed for the DTRSA investigation are presented in Table A.3-1. The analytical parameters and laboratory analytical methods requested for this investigation are presented in Table A.3-2. Samples collected for chemical analyses were analyzed by Paragon Analytics, Inc. in Ft. Collins, CO. Samples collected for radiological analyses were analyzed by Bechtel Nevada Analytical Services Laboratory, Mercury, NV. Third-party data validation was conducted by Quanterra in Knoxville, TN.

The analytical parameters were selected through the application of site process knowledge according to the Guidance for the Data Quality Objectives Process (EPA, 1994a). Preliminary action levels for off-site laboratory analytical methods were determined during the DQO process and are based on NAC 445A.2272 (NAC, 1998) and the EPA Region 9 Preliminary Remediation Goals (PRGs) (EPA, 1998) for chemical parameters under the industrial scenario. The PALs for off-site radioanalytical methods are defined in accordance with the guidance described in the Multi-Agency Radiation Survey and Site Investigation Manual (MARSSIM) (NRC, 1997). The results of the DQO process are documented in the CAIP (DOE/NV, 1998) with the remainder of the documentation retained in the project files. Sampling activities were designed to detect contaminants of potential concern and conducted to either confirm or disprove the assumptions made in the DQO process.

\section{A.3.1 Total Volatile Organic Compound Analytical Results}

The total VOC analytical results detected above minimum reporting limits as specified in the CAIP (DOE/NV, 1998) and the associated PALs are provided in Table A.3-3. The laboratory data 
Table A.3-1

Samples Collected and Analyzed During the DTRSA Subsurface Investigation (Page 1 of 3 )

\begin{tabular}{|c|c|c|c|c|c|}
\hline $\begin{array}{c}\text { Borehole } \\
\text { Number }\end{array}$ & Sample Number & $\begin{array}{c}\text { Depth }^{\mathrm{a}} \\
\text { (in ft bgs) }\end{array}$ & Sample Matrix & Sample Type & $\begin{array}{c}\text { Parameters } \\
\text { Analyzed }\end{array}$ \\
\hline \multirow{6}{*}{$N A^{b}$} & DTR00001 & NA & Water & Source Blank & Set 1 \\
\hline & DTR00002 & NA & Water & Trip Blank & VOC \\
\hline & DTR00003 & NA & Water & Field Blank & Set 1 \\
\hline & DTR00004 & NA & Water & Source Blank & Set 1 \\
\hline & DTR00005 & NA & Water & Trip Blank & VOC \\
\hline & DTR00006 & NA & Water & Trip Blank & VOC \\
\hline \multirow{5}{*}{ BG1 } & DTR00007 & 5 & Soil & Background & Set 2 \\
\hline & DTR00009 & 10 & Soil & Background & Set 2 \\
\hline & DTR00010 & 15 & Soil & Background & Set 2 \\
\hline & DTR00011 & 20 & Soil & Background & Set 2 \\
\hline & DTR00012 & NA & Water & Trip Blank & VOC \\
\hline \multirow{7}{*}{ BG2 } & DTR00013 & 1 & Soil & Background & Set 2 \\
\hline & DTR00014 & 5 & Soil & Background & Set 2 \\
\hline & DTR00015 & 10 & Soil & Background & Set 2 \\
\hline & DTR00016 & 10 & Soil & Duplicate of DTR00015 & Set 2 \\
\hline & DTR00017 & 15 & Soil & Background & Set 2 \\
\hline & DTR00018 & 20 & Soil & $\begin{array}{l}\text { Designated as an } \\
\text { MS/MSD }^{c} \text { Sample }\end{array}$ & Set 2 \\
\hline & DTR00019 & NA & Water & Trip Blank & VOC \\
\hline \multirow{8}{*}{ NB1 } & DTR00020 & NA & Water & Trip Blank & VOC \\
\hline & DTR00021 & 5 & Soil & Investigation & Set 2 \\
\hline & DTR00022 & 15 & Soil & Investigation & Set 2 \\
\hline & DTR00023 & 20 & Soil & Investigation & Set 2 \\
\hline & DTR00024 & 7 & Soil & Investigation & Set 3 \\
\hline & DTR00025 & 8 & Soil & Investigation & Set 3 \\
\hline & DTR00026 & 9 & Soil & Investigation & Set 3 \\
\hline & DTR00027 & 10 & Soil & Investigation & Set 3 \\
\hline \multirow{11}{*}{ NB2 } & DTR00028 & NA & Water & Equipment Blank & Set 1 \\
\hline & DTR00029 & NA & Water & Field Blank & Set 3 \\
\hline & DTR00030 & NA & Water & Trip Blank & VOC \\
\hline & DTR00031 & NA & Water & Trip Blank & VOC \\
\hline & DTR00032 & 5 & Soil & Investigation & Set 1 \\
\hline & DTR00033 & 15 & Soil & Investigation & Set 1 \\
\hline & DTR00034 & 20 & Soil & Investigation & Set 1 \\
\hline & DTR00035 & 6 & Soil & Investigation & Set 3 \\
\hline & DTR00036 & 7 & Soil & Investigation & Set 3 \\
\hline & DTR00037 & 8 & Soil & Investigation & Set 3 \\
\hline & DTR00038 & 10 & Soil & Investigation & Set 3 \\
\hline
\end{tabular}


Table A.3-1

Samples Collected and Analyzed During the DTRSA Subsurface Investigation (Page 2 of 3 )

\begin{tabular}{|c|c|c|c|c|c|}
\hline $\begin{array}{l}\text { Borehole } \\
\text { Number }\end{array}$ & Sample Number & $\begin{array}{l}\text { Depth }^{\mathrm{a}} \\
\text { (in ft bgs) }\end{array}$ & Sample Matrix & Sample Type & $\begin{array}{c}\text { Parameters } \\
\text { Analyzed }\end{array}$ \\
\hline \multirow{8}{*}{ NB3 } & DTR00039 & NA & Water & Trip Blank & VOC \\
\hline & DTR00040 & 5 & Soil & Investigation & Set 1 \\
\hline & DTR00041 & 15 & Soil & Investigation & Set 1 \\
\hline & DTR00042 & 20 & Soil & Investigation & Set 1 \\
\hline & DTR00043 & 6 & Soil & Investigation & Set 3 \\
\hline & DTR00044 & 7 & Soil & Investigation & Set 3 \\
\hline & DTR00045 & 8 & Soil & Investigation & Set 3 \\
\hline & DTR00046 & 10 & Soil & Investigation & Set 3 \\
\hline \multirow{9}{*}{ NB4 } & DTR00047 & NA & Water & Trip Blank & VOC \\
\hline & DTR00048 & 6 & Soil & Investigation & Set 3 \\
\hline & DTR00049 & 7 & Soil & Investigation & Set 3 \\
\hline & DTR00050 & 8 & Soil & Investigation & Set 3 \\
\hline & DTR00051 & 10 & Soil & Investigation & Set 3 \\
\hline & DTR00055 & 5 & Soil & Investigation & Set 1 \\
\hline & DTR00056 & 15 & Soil & Investigation & Set 1 \\
\hline & DTR00057 & 15 & Soil & Duplicate of DTR00056 & Set 1 \\
\hline & DTR00058 & 20 & Soil & $\begin{array}{l}\text { Designated as an } \\
\text { MS/MSD Sample }\end{array}$ & Set 1 \\
\hline \multirow{10}{*}{ SB1 } & DTR00059 & NA & Water & Field Blank & Set 1 \\
\hline & DTR00060 & NA & Water & Trip Blank & VOC \\
\hline & DTR00067 & NA & Water & Trip Blank & VOC \\
\hline & DTR00068 & 5 & Soil & Investigation & Set 1 \\
\hline & DTR00069 & 15 & Soil & Investigation & Set 1 \\
\hline & DTR00070 & 20 & Soil & Investigation & Set 1 \\
\hline & DTR00071 & 4 & Soil & Investigation & Set 3 \\
\hline & DTR00072 & 6 & Soil & Investigation & Set 3 \\
\hline & DTR00073 & 7 & Soil & Investigation & Set 3 \\
\hline & DTR00074 & 8 & Soil & Investigation & Set 3 \\
\hline \multirow{8}{*}{ SB2 } & DTR00075 & NA & Water & Trip Blank & VOC \\
\hline & DTR00076 & 5 & Soil & Investigation & Set 1 \\
\hline & DTR00077 & 15 & Soil & Investigation & Set 1 \\
\hline & DTR00078 & 20 & Soil & Investigation & Set 1 \\
\hline & DTR00079 & 6 & Soil & Investigation & Set 3 \\
\hline & DTR00080 & 7 & Soil & Investigation & Set 3 \\
\hline & DTR00081 & 8 & Soil & Investigation & Set 3 \\
\hline & DTR00082 & 10 & Soil & Investigation & Set 3 \\
\hline
\end{tabular}


Table A.3-1

Samples Collected and Analyzed During the DTRSA Subsurface Investigation (Page 3 of 3 )

\begin{tabular}{|c|c|c|c|c|c|}
\hline $\begin{array}{l}\text { Borehole } \\
\text { Number }\end{array}$ & Sample Number & $\begin{array}{l}\text { Depth }^{\mathrm{a}} \\
\text { (in ft bgs) }\end{array}$ & Sample Matrix & Sample Type & $\begin{array}{c}\text { Parameters } \\
\text { Analyzed }\end{array}$ \\
\hline \multirow{8}{*}{ SB3 } & DTR00086 & NA & Water & Trip Blank & VOC \\
\hline & DTR00087 & 10 & Soil & Investigation & Set 1 \\
\hline & DTR00088 & 15 & Soil & Investigation & Set 1 \\
\hline & DTR00089 & 20 & Soil & Investigation & Set 1 \\
\hline & DTR00090 & 3 & Soil & Investigation & Set 3 \\
\hline & DTR00091 & 4 & Soil & Investigation & Set 3 \\
\hline & DTR00092 & 6 & Soil & Investigation & Set 3 \\
\hline & DTR00094 & 5 & Soil & Investigation & Set 1 \\
\hline \multirow{10}{*}{ SB4 } & DTR00093 & 5 & Soil & Investigation & Set 1 \\
\hline & DTR00095 & 5 & Soil & Duplicate of DTR00093 & Set 1 \\
\hline & DTR00096 & 10 & Soil & $\begin{array}{l}\text { Designated as an } \\
\text { MS/MSD Sample }\end{array}$ & Set 1 \\
\hline & DTR00097 & 15 & Soil & Investigation & Set 1 \\
\hline & DTR00098 & 4 & Soil & Investigation & Set 3 \\
\hline & DTR00099 & 6 & Soil & Investigation & Set 3 \\
\hline & DTR00100 & 7 & Soil & Investigation & Set 3 \\
\hline & DTR00101 & 20 & Soil & Investigation & Set 1 \\
\hline & DTR00102 & NA & Water & Trip Blank & VOC \\
\hline & DTR00103 & NA & Water & Trip Blank & VOC \\
\hline Bag\# BK 2 & DTR00062 & NA & Soil & Background & Set 3 \\
\hline Bag\# BK 4 & DTR00063 & NA & Soil & Background & Set 3 \\
\hline Bag\# BK 10 & DTR00064 & NA & Soil & Background & Set 3 \\
\hline Bag\# BK 17 & DTR00065 & NA & Soil & Background & Set 3 \\
\hline Bag\# BK 20 & DTR00066 & NA & Soil & Background & Set 3 \\
\hline
\end{tabular}

${ }^{\mathrm{a}}$ Soil samples collected from 1-ft interval ending at depth shown.

Set 1: Analytical parameters are Total VOC, Total SVOC, TPH-Gasoline, TPH-Diesel/Oil, Total RCRA Metals, Isotopic Plutonium, Isotopic Uranium

Set 2: Total VOC, TPH-Gasoline, Isotopic Plutonium, Isotopic Uranium, Total RCRA Metals

Set 3: Analytical parameters are Isotopic Plutonium and Isotopic Uranium

${ }^{\mathrm{b}}$ Not applicable

${ }^{\mathrm{C}}$ Matrix Spike/Matrix Spike Duplicate 
Table A.3-2

Laboratory Analytical Methods Used for the DTRSA Investigation Samples

\begin{tabular}{|c|c|}
\hline Analytical Parameter & Analytical Method \\
\hline Total volatile organic compounds & EPA $8260 B^{a}$ \\
\hline Total semivolatile organic compounds & EPA $8270 C^{a}$ \\
\hline Total petroleum hydrocarbons - gasoline and diesel & EPA $8015 B(\text { modified })^{a}$ \\
\hline $\begin{array}{l}\text { Total RCRA metals (arsenic, barium, cadmium, chromium, } \\
\text { lead, selenium, silver, and mercury) }\end{array}$ & $\begin{array}{l}\text { EPA } 6010 B / 7470 A^{a} \\
\text { EPA } 6010 B / 7471 A^{a}\end{array}$ \\
\hline Isotopic Plutonium & $\begin{array}{l}\text { L-E10.601.PL }{ }^{b, c} \\
L-E 10.608 . P C\end{array}$ \\
\hline Isotopic Uranium & $\begin{array}{l}\text { L-E10.602.PL } \\
\text { L-E10.605.PL } \\
\text { L-E10.608.PC }\end{array}$ \\
\hline
\end{tabular}

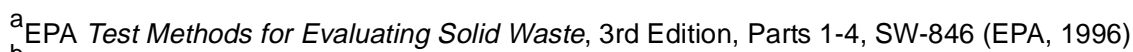

bechtel Nevada Analytical Services Laboratory Procedures Manual (BN, 1998)

${ }^{c}$ Separation and Preconcentration of Actinides from Acidic Media by Extraction Chromatography (Horwitz et al., 1993)

${ }^{d}$ Separation and Preconcentration of Uranium from Acidic Media by Extraction Chromatography (Horwitz et al., 1992)
}

indicate that constituents were either not present above the minimum reporting limits or, if present, were below the preliminary action levels.

Although the two constituents (acetone and methylene chloride) above the minimum reporting limit are common laboratory-introduced contaminants, their presence in some soil samples and QC samples cannot be attributed solely to this factor (see Section A.4.7.1). However, the concentrations of these two contaminants are well below PALs.

\section{A.3.2 Total Semivolatile Organic Compound Analytical Results}

The laboratory data indicate that constituents were either not present above the minimum reporting limits or, if present, were below the PALs.

\section{A.3.3 Total Petroleum Hydrocarbon Results}

Total petroleum hydrocarbons were not detected in either the gasoline or diesel ranges. 
Table A.3-3

Soil Sample Results for Total Volatile Organic Compounds Detected Above Minimum Reporting Limits, Double Tracks RADSAFE Area, Nellis Air Force Range

\begin{tabular}{|c|c|c|c|c|c|}
\hline \multirow{3}{*}{$\begin{array}{l}\text { Borehole } \\
\text { No. }\end{array}$} & \multirow{3}{*}{$\begin{array}{l}\text { Sample } \\
\text { No. }\end{array}$} & \multirow{2}{*}{$\begin{array}{l}\text { Start Depth } \\
\text { (ft) }\end{array}$} & \multirow{2}{*}{$\begin{array}{l}\text { End Depth } \\
\text { (ft) }\end{array}$} & \multicolumn{2}{|c|}{$\begin{array}{l}\text { Contaminant of Potential Concern } \\
\text { in micrograms per kilogram }(\mu \mathrm{g} / \mathrm{kg})\end{array}$} \\
\hline & & & & Acetone & Methylene Chloride \\
\hline & & \multicolumn{2}{|c|}{$\begin{array}{l}\text { Preliminary Action Levels } \\
(\mu \mathrm{g} / \mathrm{kg}) \\
\text { (Industrial Soil PRG) }^{\star}\end{array}$} & $6,100,000$ & 20,000 \\
\hline \multirow{4}{*}{ BG1 } & DTR00007 & 4 & 5 & $8.1(\mathrm{~J})$ & $\overline{--}$ \\
\hline & DTR00009 & 9 & 10 & $6.4(\mathrm{~J})$ & -- \\
\hline & DTR00010 & 14 & 15 & $13(\mathrm{~J})$ & $5.1(\mathrm{~J})$ \\
\hline & DTR00011 & 19 & 20 & $5.6(\mathrm{~J})$ & -- \\
\hline \multirow{5}{*}{ BG2 } & DTR00013 & 0 & 1 & 39 & -- \\
\hline & DTR00014 & 4 & 5 & $19(\mathrm{~J})$ & -- \\
\hline & DTR00015 & 9 & 10 & $15(\mathrm{~J})$ & -- \\
\hline & DTR00016 & 9 & 10 & $8.3(\mathrm{~J})$ & -- \\
\hline & DTR00017 & 14 & 15 & $5.8(\mathrm{~J})$ & -- \\
\hline \multirow{3}{*}{ NB1 } & DTR00021 & 4 & 5 & $9.7(\mathrm{~J})$ & -- \\
\hline & DTR00022 & 14 & 15 & $8.9(\mathrm{~J})$ & -- \\
\hline & DTR00023 & 19 & 20 & $5(\mathrm{~J})$ & -- \\
\hline \multirow{3}{*}{ NB2 } & DTR00032 & 4 & 5 & $8.2(\mathrm{~J})$ & -- \\
\hline & DTR00033 & 14 & 15 & $5.1(\mathrm{~J})$ & -- \\
\hline & DTR00034 & 19 & 20 & $5.8(\mathrm{~J})$ & -- \\
\hline \multirow{3}{*}{ NB3 } & DTR00040 & 4 & 5 & $7.2(\mathrm{~J})$ & -- \\
\hline & DTR00041 & 14 & 15 & $11(\mathrm{~J})$ & -- \\
\hline & DTR00042 & 19 & 20 & $6.5(\mathrm{~J})$ & -- \\
\hline NB4 & DTR00057 & 14 & 15 & $6.2(\mathrm{~J})$ & -- \\
\hline SB1 & DTR00068 & 4 & 5 & $6.8(\mathrm{~J})$ & -- \\
\hline SB2 & DTR00076 & 4 & 5 & $7.5(J)$ & -- \\
\hline SB4 & DTR00093 & 4 & 5 & $5.5(\mathrm{~J})$ & -- \\
\hline SB3 & DTR00094 & 4 & 5 & $5.9(\mathrm{~J})$ & $16(\mathrm{~J})$ \\
\hline SB4 & DTR00101 & 19 & 20 & $5.9(\mathrm{~J})$ & -- \\
\hline
\end{tabular}

* = EPA Region 9, Industrial PRGs (EPA, 1998)

$\mathrm{J}=$ Estimated value

-- = Not detected above the minimum reporting limit 


\section{A.3.4 Total RCRA Metals Results}

The total RCRA metals detected above the minimum reporting limits are presented in Table A.3-4. The total RCRA metals results were all below the PALs except for arsenic (EPA, 1998). Arsenic was detected above the Industrial PRG (3.0 milligrams per kilogram [mg/kg]) in all samples analyzed for total RCRA metals; however, these concentrations are not unusual for the state of Nevada (Shacklette and Boerngen, 1984) and are considered representative of ambient conditions. Arsenic data collected from the two background boreholes indicate levels of arsenic ranging from 6.1 to $10.5 \mathrm{mg} / \mathrm{kg}$.

\section{A.3.5 Isotopic Plutonium and Uranium Results}

Plutonium and uranium results detected above the minimum reporting limits as specified in the CAIP (DOE/NV, 1998) are presented in Table A.3-5. The results from the radioanalytical samples indicate that concentrations of radionuclides measured in the borehole soil samples are not different from soil samples taken from undisturbed background locations, and therefore do not exceed PALs.

\section{A.3.6 Geotechnical Analysis Results}

Four geotechnical samples (DTR00052, DTR00083, DTR00104, and DTR00107) were collected to provide input for closure options. Each sample was collected in three 6-in. brass sleeves using a California Modified split-spoon sampler. In each case, except for Sample DTR00107, all three sleeves were collected for geotechnical analysis. In the case of Sample DTR00107, only two sleeves were collected (representing a 1-ft interval). These samples were not submitted for analysis because the geotechnical data would not offer useful information based on the likely corrective action alternatives for DTRSA. 
Table A.3-4

Soil Sample Results for Total RCRA Metals Detected Above Minimum Reporting Limits, Double Tracks RADSAFE Area, Nellis Air Force Range

(Page 1 of 2)

\begin{tabular}{|c|c|c|c|c|c|c|c|c|c|}
\hline \multirow{3}{*}{$\begin{array}{c}\text { Borehole } \\
\text { No. }\end{array}$} & \multirow{3}{*}{$\begin{array}{c}\text { Sample } \\
\text { No. }\end{array}$} & \multirow{2}{*}{$\begin{array}{c}\text { Start } \\
\text { Depth (ft) }\end{array}$} & \multirow{2}{*}{$\begin{array}{l}\text { End } \\
\text { Depth (ft) }\end{array}$} & \multicolumn{6}{|c|}{$\begin{array}{l}\text { Contaminant of Potential Concern } \\
\text { in milligrams per kilogram }(\mathrm{mg} / \mathrm{kg})\end{array}$} \\
\hline & & & & Arsenic & Barium & Chromium & Lead & Silver & Selenium \\
\hline & & \multicolumn{2}{|c|}{$\begin{array}{l}\text { Preliminary Action } \\
\text { Levels (mg/kg) } \\
\text { (Industrial Soil PRG)* }^{*}\end{array}$} & 3.0 & 100,000 & 450 & 1,000 & 9,400 & 9,400 \\
\hline \multirow{4}{*}{ BG1 } & DTR00007 & 4 & 5 & 10.5 & 75 & 3.1 & 11.7 & -- & -- \\
\hline & DTR00009 & 9 & 10 & 6.1 & 121 & 2.1 & 10.3 & -- & -- \\
\hline & DTR00010 & 14 & 15 & 9.9 & 102 & 2.6 & 12.6 & -- & -- \\
\hline & DTR00011 & 19 & 20 & 8.3 & 78.7 & 1.8 & 10.4 & -- & -- \\
\hline \multirow{6}{*}{ BG2 } & DTR00013 & 0 & 1 & 7.1 & 93.2 & 2.1 & 8.5 & -- & -- \\
\hline & DTR00014 & 4 & 5 & 9.5 & 110 & 6.5 & 11.3 & $0.08(\mathrm{~B})$ & -- \\
\hline & DTR00015 & 9 & 10 & 7.7 & 86.9 & 3.1 & 10.2 & -- & -- \\
\hline & DTR00016 & 9 & 10 & 7.8 & 91.4 & 3.2 & 9.6 & -- & -- \\
\hline & DTR00017 & 14 & 15 & 9.6 & 89 & 3.1 & 13.9 & -- & -- \\
\hline & DTR00018 & 19 & 20 & 10.0 & 91.2 & 2.8 & 14.4 & -- & -- \\
\hline \multirow{3}{*}{ NB1 } & DTR00021 & 4 & 5 & 6.6 & 87.9 & 1.8 & 14.3 & -- & -- \\
\hline & DTR00022 & 14 & 15 & 7.1 & 292 & 6.2 & 9.6 & -- & -- \\
\hline & DTR00023 & 19 & 20 & 8.8 & 155 & 5 & 10.5 & -- & -- \\
\hline \multirow{3}{*}{ NB2 } & DTR00032 & 4 & 5 & 7.4 & 74.8 & 2.7 & 10.4 & -- & -- \\
\hline & DTR00033 & 14 & 15 & 9.9 & 156 & 4 & 15.3 & -- & -- \\
\hline & DTR00034 & 19 & 20 & 6.8 & 69.5 & 1.8 & 10.4 & -- & -- \\
\hline \multirow{3}{*}{ NB3 } & DTR00040 & 4 & 5 & 8.4 & 135 & 8.6 & 16 & -- & 1.2 \\
\hline & DTR00041 & 14 & 15 & 11.6 & 112 & 5 & 14.2 & $0.56(\mathrm{~B})$ & -- \\
\hline & DTR00042 & 19 & 20 & 8.1 & 74.6 & 2 & 9.1 & -- & -- \\
\hline \multirow{4}{*}{ NB4 } & DTR00055 & 4 & 5 & 8.0 & 90.6 & 3.8 & 13.3 & -- & -- \\
\hline & DTR00056 & 14 & 15 & 9.2 & 111 & 4 & 11.7 & -- & -- \\
\hline & DTR00057 & 14 & 15 & 10.4 & 129 & 4.1 & 14.9 & -- & -- \\
\hline & DTR00058 & 19 & 20 & 7.9 & 76.8 & 3.1 & 14.5 & -- & -- \\
\hline
\end{tabular}


Table A.3-4

Soil Sample Results for Total RCRA Metals Detected Above Minimum Reporting
Limits, Double Tracks RADSAFE Area, Nellis Air Force Range (Page 2 of 2)

\begin{tabular}{|c|c|c|c|c|c|c|c|c|c|}
\hline \multirow{3}{*}{$\begin{array}{l}\text { Borehole } \\
\text { No. }\end{array}$} & \multirow{3}{*}{$\begin{array}{l}\text { Sample } \\
\text { No. }\end{array}$} & \multirow{2}{*}{$\begin{array}{c}\text { Start } \\
\text { Depth (ft) }\end{array}$} & \multirow{2}{*}{$\begin{array}{l}\text { End } \\
\text { Depth (ft) }\end{array}$} & \multicolumn{6}{|c|}{$\begin{array}{l}\text { Contaminant of Potential Concern } \\
\text { in milligrams per kilogram }(\mathrm{mg} / \mathrm{kg})\end{array}$} \\
\hline & & & & Arsenic & Barium & Chromium & Lead & Silver & Selenium \\
\hline & & $\begin{array}{r}\text { Prelimir } \\
\text { Level } \\
\text { (Industria }\end{array}$ & $\begin{array}{l}\text { y Action } \\
\text { mg/kg) } \\
\text { Soil PRG)* }\end{array}$ & 3.0 & 100,000 & 450 & 1,000 & 9,400 & 9,400 \\
\hline \multirow{3}{*}{ SB1 } & DTR00068 & 4 & 5 & 12.1 & 90 & 2.5 & 11.3 & -- & -- \\
\hline & DTR00069 & 14 & 15 & 10.3 & 121 & 3.3 & 15.2 & -- & 0.63 \\
\hline & DTR00070 & 19 & 20 & 6.2 & 60 & 2.5 & 9.6 & -- & -- \\
\hline \multirow{3}{*}{ SB2 } & DTR00076 & 4 & 5 & 10.1 & 102 & 4 & 11.6 & -- & 0.67 \\
\hline & DTR00077 & 14 & 15 & 11.4 & 101 & 2 & 14 & -- & $0.51(\mathrm{~B})$ \\
\hline & DTR00078 & 19 & 20 & 8.9 & 65.6 & 2.3 & 12 & -- & -- \\
\hline \multirow{4}{*}{ SB3 } & DTR00087 & 9 & 10 & 9.0 & 93.5 & 2.6 & 13.1 & -- & -- \\
\hline & DTR00088 & 14 & 15 & 10.3 & 123 & 3.8 & 13.3 & -- & -- \\
\hline & DTR00089 & 19 & 20 & 7.6 & 68.7 & 1.9 & 14.5 & -- & -- \\
\hline & DTR00094 & 4 & 5 & 8.0 & 88.3 & 2.6 & 10.2 & -- & -- \\
\hline \multirow{5}{*}{ SB4 } & DTR00093 & 4 & 5 & 12.9 & 98.5 & 3 & 14 & -- & -- \\
\hline & DTR00095 & 4 & 5 & 8.8 & 69.9 & 2.3 & 8.4 & -- & -- \\
\hline & DTR00096 & 9 & 10 & 9.9 & 110 & 3.1 & 13.1 & -- & -- \\
\hline & DTR00097 & 14 & 15 & 10.1 & 124 & 3.4 & 14 & -- & 0.67 \\
\hline & DTR00101 & 19 & 20 & 7.9 & 100 & 3.8 & 10.7 & -- & -- \\
\hline
\end{tabular}

* = EPA Region 9, Industrial PRGs (EPA, 1998)

$\mathrm{B}=$ Reported value is above Instrument Detection Limit but below the Contract Required Detection Limit

-- = Not detected above the minimum reporting limit 
Table A.3-5

Soil Sample Results for Isotopic Plutonium and Isotopic Uranium Detected above Minimum Reporting Limits, Double Tracks RADSAFE Area, Nellis Air Force Range

(Page 1 of 3 )

\begin{tabular}{|c|c|c|c|c|c|c|}
\hline \multirow{2}{*}{$\begin{array}{l}\text { Borehole } \\
\text { No. }\end{array}$} & \multirow{2}{*}{$\begin{array}{l}\text { Sample } \\
\text { No. }\end{array}$} & \multirow{2}{*}{$\begin{array}{c}\text { Start } \\
\text { Depth } \\
\text { (ft) }\end{array}$} & \multirow{2}{*}{$\begin{array}{c}\text { End } \\
\text { Depth } \\
\text { (ft) }\end{array}$} & \multicolumn{3}{|c|}{$\begin{array}{l}\text { Contaminant of Potential Concern } \\
\text { in picocuries per gram ( } \mathrm{pCi} / \mathrm{g})\end{array}$} \\
\hline & & & & Plutonium-239,240 & Uranium-234 & Uranium-238 \\
\hline \multicolumn{4}{|c|}{ Background Concentration $^{\mathrm{a}}$} & $0.0003-0.24^{b}$ & $0.10-2.6^{c}$ & $0.21-3.2^{b}$ \\
\hline \multirow{4}{*}{ BG1 } & DTR00007 & 4.00 & 5.00 & -- & $0.84 \pm 0.18(\mathrm{~J})$ & $0.78 \pm 0.17(\mathrm{~J})$ \\
\hline & DTR00009 & 09.00 & 10.00 & -- & $1.3 \pm 0.25(\mathrm{~J})$ & $1.2 \pm 0.24(\mathrm{~J})$ \\
\hline & DTR00010 & 14.00 & 15.00 & -- & $0.91 \pm 0.21(\mathrm{~J})$ & $1.1 \pm 0.23(\mathrm{~J})$ \\
\hline & DTR00011 & 19.00 & 20.00 & -- & $1.1 \pm 0.21(\mathrm{~J})$ & $1.0 \pm 0.19(\mathrm{~J})$ \\
\hline \multirow{6}{*}{ BG2 } & DTR00013 & 0.00 & 1.00 & -- & $0.67 \pm 0.16(\mathrm{~J})$ & $0.61 \pm 0.15(\mathrm{~J})$ \\
\hline & DTR00014 & 4.00 & 5.00 & -- & $1.6 \pm 0.27(\mathrm{~J})$ & $1.0 \pm 0.21(\mathrm{~J})$ \\
\hline & DTR00015 & 9.00 & 10.00 & -- & $1.3 \pm 0.26(\mathrm{~J})$ & $1.2 \pm 0.25(\mathrm{~J})$ \\
\hline & DTR00016 & 9.00 & 10.00 & -- & $1.5 \pm 0.27(\mathrm{~J})$ & $1.2 \pm 0.24(\mathrm{~J})$ \\
\hline & DTR00017 & 14.00 & 15.00 & -- & $1.1 \pm 0.21(\mathrm{~J})$ & $0.87 \pm 0.18(\mathrm{~J})$ \\
\hline & DTR00018 & 19.00 & 20.00 & -- & $1.0 \pm 0.20(\mathrm{~J})$ & $0.87 \pm 0.18(\mathrm{~J})$ \\
\hline \multirow{7}{*}{ NB1 } & DTR00021 & 4.00 & 5.00 & -- & $1.2 \pm 0.24(\mathrm{~J})$ & $1.1 \pm 0.22(\mathrm{~J})$ \\
\hline & DTR00022 & 14.00 & 15.0 & -- & $0.91 \pm 0.18(\mathrm{~J})$ & $0.91 \pm 0.18(\mathrm{~J})$ \\
\hline & DTR00023 & 19.0 & 20.0 & -- & $1.0 \pm 0.20(\mathrm{~J})$ & $1.1 \pm 0.20(\mathrm{~J})$ \\
\hline & DTR00024 & 6.00 & 7.00 & -- & $0.89 \pm 0.19(\mathrm{~J})$ & $0.81 \pm 0.18(\mathrm{~J})$ \\
\hline & DTR00025 & 7.00 & 8.00 & -- & $1.1 \pm 0.22(\mathrm{~J})$ & $0.98 \pm 0.20(\mathrm{~J})$ \\
\hline & DTR00026 & 8.00 & 9.00 & -- & $1.2 \pm 0.22(\mathrm{~J})$ & $0.94 \pm 0.19(\mathrm{~J})$ \\
\hline & DTR00027 & 9.00 & 10.00 & -- & $1.6 \pm 0.27(\mathrm{~J})$ & $1.3 \pm 0.24(\mathrm{~J})$ \\
\hline \multirow{7}{*}{ NB2 } & DTR00032 & 4.00 & 5.00 & -- & $2.2 \pm 0.33(\mathrm{~J})$ & $1.4 \pm 0.25(\mathrm{~J})$ \\
\hline & DTR00033 & 14.00 & 15.00 & -- & $1.7 \pm 0.29(\mathrm{~J})$ & $1.4 \pm 0.26(\mathrm{~J})$ \\
\hline & DTR00034 & 19.00 & 20.00 & -- & $1.2 \pm 0.22(\mathrm{~J})$ & $1.0 \pm 0.20(\mathrm{~J})$ \\
\hline & DTR00035 & 5.00 & 6.00 & -- & $1.3 \pm 0.23(\mathrm{~J})$ & $1.1 \pm 0.21(\mathrm{~J})$ \\
\hline & DTR00036 & 6.00 & 7.00 & -- & $2.7 \pm 0.36(\mathrm{~J})$ & $2.2 \pm 0.32(\mathrm{~J})$ \\
\hline & DTR00037 & 7.00 & 8.00 & -- & $1.3 \pm 0.23(\mathrm{~J})$ & $1.2 \pm 0.21(\mathrm{~J})$ \\
\hline & DTR00038 & 9.00 & 10.00 & -- & $1.8 \pm 0.27(\mathrm{~J})$ & $1.4 \pm 0.23(\mathrm{~J})$ \\
\hline
\end{tabular}


Table A.3-5

Soil Sample Results for Isotopic Plutonium and Isotopic Uranium Detected above Minimum Reporting Limits, Double Tracks RADSAFE Area, Nellis Air Force Range

(Page 2 of 3 )

\begin{tabular}{|c|c|c|c|c|c|c|}
\hline \multirow{2}{*}{$\begin{array}{l}\text { Borehole } \\
\text { No. }\end{array}$} & \multirow{2}{*}{$\begin{array}{l}\text { Sample } \\
\text { No. }\end{array}$} & \multirow{2}{*}{$\begin{array}{c}\text { Start } \\
\text { Depth } \\
\text { (ft) }\end{array}$} & \multirow{2}{*}{$\begin{array}{c}\text { End } \\
\text { Depth } \\
\text { (ft) }\end{array}$} & \multicolumn{3}{|c|}{$\begin{array}{l}\text { Contaminant of Potential Concern } \\
\text { in picocuries per gram }(\mathrm{pCi} / \mathrm{g})\end{array}$} \\
\hline & & & & Plutonium-239,240 & Uranium-234 & Uranium-238 \\
\hline \multirow{7}{*}{ NB3 } & DTR00040 & 4.00 & 5.00 & $0.21 \pm 0.10(\mathrm{~J})$ & $1.1 \pm 0.21(\mathrm{~J})$ & $1.1 \pm 0.21(\mathrm{~J})$ \\
\hline & DTR00041 & 14.0 & 15.0 & -- & $1.5 \pm 0.25(\mathrm{~J})$ & $1.4 \pm 0.24(\mathrm{~J})$ \\
\hline & DTR00042 & 19.0 & 20.0 & -- & $2.2 \pm 0.33(\mathrm{~J})$ & $2.1 \pm 0.32(\mathrm{~J})$ \\
\hline & DTR00043 & 5.00 & 6.00 & -- & $1.7 \pm 0.27(\mathrm{~J})$ & $1.3 \pm 0.23(\mathrm{~J})$ \\
\hline & DTR00044 & 6.00 & 7.00 & -- & $2.0 \pm 0.29(\mathrm{~J})$ & $1.4 \pm 0.23(\mathrm{~J})$ \\
\hline & DTR00045 & 7.00 & 8.00 & -- & $1.1 \pm 0.24(\mathrm{~J})$ & $1.0 \pm 0.24(\mathrm{~J})$ \\
\hline & DTR00046 & 9.00 & 10.00 & -- & $1.5 \pm 0.25(\mathrm{~J})$ & $1.4 \pm 0.24(\mathrm{~J})$ \\
\hline \multirow{8}{*}{ NB4 } & DTR00048 & 5.0 & 6.0 & -- & $0.83 \pm 0.17(\mathrm{~J})$ & $0.77 \pm 0.16(\mathrm{~J})$ \\
\hline & DTR00049 & 6.0 & 7.0 & -- & $1.3 \pm 0.26(\mathrm{~J})$ & $1.3 \pm 0.26(\mathrm{~J})$ \\
\hline & DTR00050 & 7.0 & 8.0 & -- & $1.1 \pm 0.23(\mathrm{~J})$ & $0.94 \pm 0.21(\mathrm{~J})$ \\
\hline & DTR00051 & 9.0 & 10.0 & -- & $1.6 \pm 0.29(\mathrm{~J})$ & $1.3 \pm 0.25(\mathrm{~J})$ \\
\hline & DTR00055 & 4.0 & 5.0 & -- & $1.3 \pm 0.23(\mathrm{~J})$ & $1.2 \pm 0.22(\mathrm{~J})$ \\
\hline & DTR00056 & 14.0 & 15.0 & -- & $1.9 \pm 0.30(\mathrm{~J})$ & $1.6 \pm 0.27(\mathrm{~J})$ \\
\hline & DTR00057 & 14.0 & 15.0 & -- & $1.5 \pm 0.26(\mathrm{~J})$ & $1.4 \pm 0.25(\mathrm{~J})$ \\
\hline & DTR00058 & 19.0 & 20.0 & -- & $1.2 \pm 0.22(\mathrm{~J})$ & $1.2 \pm 0.22(\mathrm{~J})$ \\
\hline Bag\# BK 2 & DTR00062 & NA & NA & $0.17 \pm 0.08(\mathrm{~J})$ & $1.0 \pm 0.22(\mathrm{~J})$ & $1.0 \pm 0.22(\mathrm{~J})$ \\
\hline Bag\# BK 4 & DTR00063 & NA & NA & -- & $1.4 \pm 0.26(\mathrm{~J})$ & $1.2 \pm 0.25(\mathrm{~J})$ \\
\hline Bag\# BK 10 & DTR00064 & NA & NA & -- & $0.93 \pm 0.18(\mathrm{~J})$ & $0.86 \pm 0.17(\mathrm{~J})$ \\
\hline Bag\# BK 17 & DTR00065 & NA & NA & -- & $1.4 \pm 0.23(\mathrm{~J})$ & $1.2 \pm 0.21(\mathrm{~J})$ \\
\hline Bag\# BK 20 & DTR00066 & NA & NA & $0.15 \pm 0.07(\mathrm{~J})$ & $1.0 \pm 0.21(\mathrm{~J})$ & $0.88 \pm 0.19(\mathrm{~J})$ \\
\hline \multirow{7}{*}{ SB1 } & DTR00068 & 4.0 & 5.0 & -- & $1.6 \pm 0.27(\mathrm{~J})$ & $1.5 \pm 0.26(\mathrm{~J})$ \\
\hline & DTR00069 & 14.0 & 15.0 & -- & $1.4 \pm 0.25(\mathrm{~J})$ & $1.3 \pm 0.24(\mathrm{~J})$ \\
\hline & DTR00070 & 19.0 & 20.0 & -- & $1.3 \pm 0.24(\mathrm{~J})$ & $1.5 \pm 0.25(\mathrm{~J})$ \\
\hline & DTR00071 & 3.0 & 4.0 & -- & $1.9 \pm 0.29(\mathrm{~J})$ & $1.4 \pm 0.25(\mathrm{~J})$ \\
\hline & DTR00072 & 5.0 & 6.0 & -- & $1.5 \pm 0.25(\mathrm{~J})$ & $1.2 \pm 0.22(\mathrm{~J})$ \\
\hline & DTR00073 & 6.0 & 7.0 & -- & $1.4 \pm 0.23(\mathrm{~J})$ & $1.2 \pm 0.21(\mathrm{~J})$ \\
\hline & DTR00074 & 7.0 & 8.0 & -- & $1.4 \pm 0.26(\mathrm{~J})$ & $1.1 \pm 0.22(\mathrm{~J})$ \\
\hline
\end{tabular}


Table A.3-5

Soil Sample Results for Isotopic Plutonium and

Isotopic Uranium Detected above Minimum Reporting Limits, Double Tracks RADSAFE Area, Nellis Air Force Range

(Page 3 of 3 )

\begin{tabular}{|c|c|c|c|c|c|c|}
\hline \multirow{2}{*}{$\begin{array}{l}\text { Borehole } \\
\text { No. }\end{array}$} & \multirow{2}{*}{$\begin{array}{l}\text { Sample } \\
\text { No. }\end{array}$} & \multirow{2}{*}{$\begin{array}{c}\text { Start } \\
\text { Depth } \\
\text { (ft) }\end{array}$} & \multirow{2}{*}{$\begin{array}{c}\text { End } \\
\text { Depth } \\
\text { (ft) }\end{array}$} & \multicolumn{3}{|c|}{$\begin{array}{l}\text { Contaminant of Potential Concern } \\
\text { in picocuries per gram }(\mathrm{pCi} / \mathrm{g})\end{array}$} \\
\hline & & & & Plutonium-239,240 & Uranium-234 & Uranium-238 \\
\hline \multirow{7}{*}{ SB2 } & DTR00076 & 4.0 & 5.0 & $\overline{---}$ & $2.3 \pm 0.32(\mathrm{~J})$ & $1.6 \pm 0.25(\mathrm{~J})$ \\
\hline & DTR00077 & 14.0 & 15.0 & -- & $1.1 \pm 0.21(\mathrm{~J})$ & $1.0 \pm 0.21(\mathrm{~J})$ \\
\hline & DTR00078 & 19.0 & 20.0 & -- & $0.77 \pm 0.18(\mathrm{~J})$ & $0.94 \pm 0.20(\mathrm{~J})$ \\
\hline & DTR00079 & 5.0 & 6.0 & -- & $1.4 \pm 0.26(\mathrm{~J})$ & $0.95 \pm 0.21(\mathrm{~J})$ \\
\hline & DTR00080 & 6.0 & 7.0 & -- & $2.5 \pm 0.37(\mathrm{~J})$ & $1.9 \pm 0.30(\mathrm{~J})$ \\
\hline & DTR00081 & 7.0 & 8.0 & -- & $1.3 \pm 0.24(\mathrm{~J})$ & $1.0 \pm 0.20(\mathrm{~J})$ \\
\hline & DTR00082 & 9.0 & 10.0 & -- & $1.5 \pm 0.24(\mathrm{~J})$ & $1.0 \pm 0.20(\mathrm{~J})$ \\
\hline \multirow{7}{*}{ SB3 } & DTR00087 & 9.0 & 10.0 & -- & $1.1 \pm 0.21(\mathrm{~J})$ & $1.0 \pm 0.20(\mathrm{~J})$ \\
\hline & DTR00088 & 14.0 & 15.0 & -- & $1.4 \pm 0.24(\mathrm{~J})$ & $1.4 \pm 0.23(\mathrm{~J})$ \\
\hline & DTR00089 & 19.0 & 20.0 & -- & $1.3 \pm 0.22(\mathrm{~J})$ & $1.4 \pm 0.24(\mathrm{~J})$ \\
\hline & DTR00090 & 2.0 & 3.0 & -- & $1.0 \pm 0.20(\mathrm{~J})$ & $1.2 \pm 0.22(\mathrm{~J})$ \\
\hline & DTR00091 & 3.0 & 4.0 & -- & $0.71 \pm 0.17(\mathrm{~J})$ & $0.43 \pm 0.13(\mathrm{~J})$ \\
\hline & DTR00092 & 5.0 & 6.0 & -- & $0.39 \pm 0.12(\mathrm{~J})$ & $0.42 \pm 0.12(\mathrm{~J})$ \\
\hline & DTR00094 & 4.0 & 5.0 & -- & $1.7 \pm 0.27(\mathrm{~J})$ & $1.5 \pm 0.25(\mathrm{~J})$ \\
\hline \multirow{8}{*}{ SB4 } & DTR00093 & 4.0 & 5.0 & -- & $2.5 \pm 0.35(\mathrm{~J})$ & $2.0 \pm 0.30(\mathrm{~J})$ \\
\hline & DTR00095 & 4.00 & 5.00 & -- & $2.9 \pm 0.39(\mathrm{~J})$ & $1.9 \pm 0.29(\mathrm{~J})$ \\
\hline & DTR00096 & 9.0 & 10.0 & -- & $1.7 \pm 0.28(\mathrm{~J})$ & $1.4 \pm 0.25(\mathrm{~J})$ \\
\hline & DTR00097 & 14.0 & 15.0 & -- & $1.8 \pm 0.29(\mathrm{~J})$ & $1.7 \pm 0.28(\mathrm{~J})$ \\
\hline & DTR00098 & 3.0 & 4.0 & -- & $1.7 \pm 0.27(\mathrm{~J})$ & $1.4 \pm 0.24(\mathrm{~J})$ \\
\hline & DTR00099 & 5.0 & 6.0 & -- & $1.4 \pm 0.25(\mathrm{~J})$ & $1.3 \pm 0.24(\mathrm{~J})$ \\
\hline & DTR00100 & 6.0 & 7.0 & -- & $1.4 \pm 0.26(\mathrm{~J})$ & $1.0 \pm 0.21(\mathrm{~J})$ \\
\hline & DTR00101 & 19.0 & 20.0 & -- & $1.2 \pm 0.23(\mathrm{~J})$ & $1.0 \pm 0.21(\mathrm{~J})$ \\
\hline
\end{tabular}

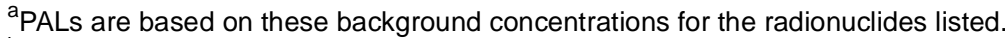

${ }^{\mathrm{b}}$ McArthur and Miller, 1989

${ }^{c}$ Atlan-Tech, 1992

$\mathrm{J}=$ Estimated value

-- = Not detected above the Minimum Detectable Activity
} 


\section{A.4.0 Quality Assurance}

The results of QA/QC activities for the DTRSA corrective action investigation sampling event are summarized in the following text. A discussion about measurement of the QA/QC objectives and documentation of nonconformances is also included. Detailed information regarding the QA program is contained in the Industrial Sites QAPP (DOE/NV, 1996b).

Quality control results are typically discussed in terms of precision, accuracy, representativeness, completeness, and comparability. These terms are described in the following sections.

\section{A.4.1 Precision}

Precision is a quantitative measure of the variability of a group of measurements from their average value. Precision is assessed for inorganic analysis by collecting and analyzing duplicate field samples and comparing the results with the original sample. Precision is also assessed by creating, analyzing, and comparing laboratory duplicates from one or more field samples in inorganic analyses and MS/MSD samples for organic analyses. Precision is reported as relative percent difference (RPD) which is calculated as the difference between the measured concentrations of duplicate samples, divided by the average of the two concentrations, and multiplied by 100 . Any deviations from these requirements have been documented and explained and the related data qualified accordingly. The qualification process is described in Section A.4.7.1.

\section{A.4.2 Accuracy}

Analytical accuracy is defined as the nearness of a measurement to the true or accepted reference value. It is the composite of the random and systematic components of the measurement system and measures bias in a measurement system. The random component of accuracy is measured and documented through the analyses of spiked samples. Sampling accuracy is assessed by evaluating the results of spiked samples and laboratory control samples. Accuracy measurements are calculated as percent recovery by dividing the measured sample concentration by the true concentration and multiplying the quotient by 100 . 
Field accuracy is assessed by confirming that the documents of record track the sample from origin, through transfer of custody, to disposal. The goal of field accuracy is for all samples to be collected from the correct locations at the correct time, placed in a correctly labeled container with the correct preservative, and sealed with custody tape to prevent tampering. All samples in this sampling event were properly collected and forwarded to the laboratory as described above.

\section{A.4.3 Representativeness}

Representativeness expresses the degree to which sample data accurately and precisely represent a characteristic of a population, parameter variations at a sampling point, or an environmental condition (EPA, 1987). Sample representativeness was achieved through the implementation of a sampling program designed to ensure proper sampling locations, number of samples, and the use of validated analytical methods. Representativeness was assessed through analysis of duplicate samples. Representativeness of the samples taken in this sampling event was assured by collecting the specified number of samples (DOE/NV, 1998) and by analyzing them using the approved analytical methods shown in Table A.3-2.

\section{A.4.4 Completeness}

Completeness is defined as the percentage of measurements made that are judged to be valid. A sampling and analytical requirement of 80 percent completeness was established and achieved for this project (DOE/NV, 1996b).

The specified sampling locations were utilized as planned. All samples were collected as specified in the CAIP (DOE/NV, 1998); however, upon submittal for analysis a field nonconformance was documented for samples in boreholes BG1, BG2, and NB1 (see Section A.4.8). All sample containers reached the laboratory intact and properly preserved (when applicable). Sample temperature was maintained during shipment to the laboratory, and sample chain of custody was maintained during sample storage and/or shipment (DOE/NV, 1996b). 


\section{A.4.5 Comparability}

Comparability is a qualitative parameter expressing the confidence with which one data set can be compared to another (EPA, 1987). To ensure comparability, the DTRSA field sampling activities were performed and documented in accordance with approved procedures, and all samples were collected per the CAIP (DOE/NV, 1998). Approved standardized methods and procedures were also used to analyze and report the data (e.g., Contract Laboratory Program [CLP] and/or CLP-like data packages). This approach ensures that the data from this project can be compared to other data sets. Based on the minimum comparability requirements specified in the Industrial Sites QAPP (DOE/NV, 1996b), all requirements were met.

Field (i.e., sample-handling) documentation, laboratory nonconformance reports, and the precision and accuracy of quality-control sample results were evaluated for their effect on the results of the associated environmental soil samples. The environmental sample results were then qualified according to processes outlined in the following section. Documentation of the data qualifications resulting from these reviews is retained in project files as both hard copy and electronic media.

\section{A.4.6 Tier I and Tier II Data Evaluations}

All laboratory data from samples collected at the DTRSA have been evaluated for data quality according to EPA Functional Guidelines (EPA, 1994b; 1994c). These guidelines were implemented in a tiered process and are presented in the following text. There was no rejected data for this project. Only valid data, whether estimated (i.e., J-qualified) or not, were used.

Changes resulting from the data evaluation process are documented in project files and summarized in memoranda for each sample delivery group (SDG). These memoranda are maintained with the SDGs in the IT project files.

\section{A.4.6.1 Tier I Evaluation}

Tier I evaluation for both chemical and radiological analysis examines (but is not limited to):

- Sample count/type consistent with chain of custody

- Analysis count/type consistent with chain of custody 
- Correct sample matrix

- Significant problems stated in cover letter or case narrative

- Completeness of certificates of analysis

- Completeness of CLP or CLP-like packages

- Completeness of signatures, dates, and times on chain of custody

- Condition-upon-receipt variance form included

- Requested analyses performed on all samples

- Date received/analyzed given for each sample

- Correct concentration units indicated

- Electronic data transfer supplied

- Results reported for field and laboratory QC samples

- Whether or not the deliverable met the overall objectives of the project

\section{A.4.6.2 Tier II Evaluation}

Tier II evaluation for both chemical and radiological analysis examines (but is not limited to):

\section{Chemical:}

- Correct detection limits achieved

- Sample date, preparation date, and analysis date for each sample

- Holding time criteria met

- QC batch association for each sample

- Cooler temperature upon receipt

- Sample $\mathrm{pH}$ for aqueous samples, as required

- Detection limits properly adjusted for dilution, as required

- Blank contamination evaluated and applied to sample results/qualifiers

- Matrix spike/matrix spike duplicate percent recoveries (\%R) and RPDs evaluated and applied to laboratory results/qualifiers

- Field duplicate RPDs evaluated using professional judgement and applied to laboratory results/qualifiers

- Laboratory duplicate RPDs evaluated and applied to laboratory results/qualifiers

- Surrogate \%Rs evaluated and applied to laboratory results/qualifiers

- Laboratory control sample \%R evaluated and applied to laboratory results/qualifiers

- Initial and continuing calibration evaluated and applied to laboratory results/qualifiers

- Internal standard evaluated and applied to laboratory results/qualifiers

- Recalculation of 10 percent of laboratory results from raw data

\section{Radioanalytical:}

- Correct detection limits achieved

- Blank contamination evaluated and applied to sample results/qualifiers 
- Certificate of Analysis consistent with data package documentation

- Quality control sample results (duplicates, laboratory control samples, MS/MSD) evaluated and applied to laboratory result qualifiers

- Sample results, error, and minimum detectable activity evaluated and applied to laboratory result qualifiers

- Detector system calibrated to National Institute for Standards and Technology (NIST) traceable sources

- Calibration sources preparation was documented, demonstrating proper preparation and appropriateness for sample matrix, emission energies, and concentrations

- Detector system response to daily, weekly, and monthly background and calibration checks for peak energy, peak centroid, peak full-width half-maximum, and peak efficiency

- Tracers NIST-traceable, appropriate for the analysis performed, and recoveries that met QC requirements

- Documentation of all QC sample preparation complete and properly performed

- Spectra lines, emissions, particle energies, peak areas, and background peak areas support the identified radionuclide and its concentration

\section{A.4.6.3 Tier III Evaluation}

Data quality considerations that are included in EPA data review functional guidelines (EPA, 1994b; 1994c) as a Tier III review include the additional evaluations:

\section{Chemical:}

- Mass spectrometer tuning criteria

- Initial and continuing calibration verification

- Internal standard evaluation

- Organic compound quantitation

- Inductively coupled plasma interference check sample evaluation

- Graphite furnace atomic absorption quality control

- Inductively coupled plasma serial dilution effects

- Recalculation of all laboratory results from raw data

\section{Radioanalytical:}

- QC sample results (e.g., calibration source concentration, percent recovery, and RPD) verified

- Radionuclides and their concentration appropriate considering their decay schemes, half-lives, and process knowledge and history of the facility and site

- Each identified line in spectra verified against emission libraries and calibration results

- Independent identification of spectra lines, area under the peaks, and quantification of radionuclide concentration in a random number of sample results 
A Tier III review of at least five percent of the sample analytical data was performed by Quanterra in Knoxville, TN. There were no changes to the analytical data summaries as a result of the Tier III review.

\section{A.4.7 Quality Control Samples}

Twenty-eight quality control samples (i.e., 16 trip blanks, 1 equipment rinsate blanks, 3 field blanks, 2 source blanks, 3 field duplicates, and 3 MS/MSD) were collected and submitted for laboratory analysis, as shown in Table A.3-1. The blanks and duplicates were assigned individual sample numbers and sent to the laboratory "blind." Additional samples were selected by the laboratory to be analyzed as laboratory duplicates. Documentation related to the collection and analysis of these samples is retained in project files.

\section{A.4.7.1 Field Quality Control Samples}

Field blanks, source blanks, and equipment rinsate blanks were analyzed for the parameters listed in Table A.3-2 and trip blanks were analyzed for VOCs only. These blank detections were used to qualify the results of the associated environmental samples according to EPA Functional Guidelines (EPA, 1994b; 1994c). Several contaminants (acetone, methylene chloride, 2-butanone, chloroform, bromodichloromethane, chloromethane, and 2-hexanone) were detected but they were below the contract-required detection limits (CRDLs) and could be attributed to laboratory-introduced contamination. There were a few detections of acetone and methylene chloride above the CRDLs that cannot be solely attributed to laboratory contamination.

Review of the field-collected blank analytical data for the investigation sampling indicates that cross-contamination from the field methods did not occur during sample collection. Although detections of acetone, bromodichloromethane, and 2-butanone were recorded in trip blanks, the levels were below the CRDLs which are indicative of laboratory-introduced contamination.

Three field duplicate soil samples were sent as blind samples to the laboratory to be analyzed for the analytical parameters listed in Table A.3-2. For these samples, the duplicate results precision (i.e., RPD between the environmental sample results and their corresponding field duplicate sample results) were evaluated to the guidelines set forth in EPA Functional Guidelines (EPA, 1994b; 
1994c). The EPA Functional Guidelines state that there are no required review criteria for field duplicate analyses comparability, but allow the data reviewer to exercise professional judgement. The RPD between some environmental sample results and their corresponding field duplicate sample results exceeded the 20 percent criteria stated in the Industrial Sites QAPP (DOE/NV, 1996b) for some target analytes. The variability in the results between the environmental samples and their corresponding field duplicate samples could be attributed to laboratory performance instead of field sampling performance.

Three field samples were selected for use as MS/MSD samples. The $\% \mathrm{R}$ of these samples (a measure of accuracy) and the RPDs in these sample results (a measure of precision) were compared to EPA Functional Guideline criteria (EPA, 1994b; 1994c). The results were used to qualify associated environmental sample results accordingly.

The EPA Functional Guidelines for review of organic data state that no data qualification action is taken on the basis of MS/MSD results alone (EPA, 1994b). The data reviewer exercises professional judgment in considering these results in conjunction with the results of laboratory control samples and other QC criteria in applying qualifiers to the data.

The EPA Functional Guidelines for inorganic data review allow professional judgment to be applied in evaluating the results of matrix spikes (EPA, 1994c). If spike recovery is greater than the upper acceptance limit or less than the lower acceptance limit, positive results are qualified as estimated $(\mathrm{J})$, and nondetections are qualified as estimated (UJ), respectively. If spike recovery is grossly low (less than 30 percent), positive results are not qualified, and nondetections are qualified as unusable (R).

\section{A.4.7.2 Laboratory Quality Control Samples}

Analysis of method QC blanks and surrogate spikes for organic analyses, method blanks, preparation blanks, initial and continuing calibration blanks for total metals, and laboratory control samples (LCS) were performed for each SDG by Paragon Analytical, Inc. The results of these analyses were used to qualify associated environmental sample results according to EPA Functional Guidelines (EPA, 1994b; 1994c). 
According to the EPA Functional Guidelines (EPA, 1994b; 1994c), no qualification action is taken if a compound is found in an associated blank, but not in the sample, or if a compound is found in the sample, but not in an associated blank. The action taken when a compound is detected in both the sample and the associated blank varies depending upon the analyte involved and is known as "The 5X/10X Rule."

For most VOCs, SVOCs, pesticides, and polychlorinated biphenyls, an analyte detected in the sample that was also detected in an associated blank is qualified as undetected (U) if the sample concentration is less than five times $(5 \mathrm{X})$ the blank concentration.

For the common laboratory contaminants (methylene chloride, acetone, 2-butanone [methyl ethyl ketone], and phthalate esters [especially bis(2-ehtylhexyl)phthalate]), the factor is raised to ten times (10X) the blank concentration. For both the 5X/10X Rule, the sample result is elevated to the quantitation limit if it is less than the quantitation limit or remains unaltered if the sample result is greater than or equal to the quantitation limit, and qualified as undetected (U).

For inorganics (i.e., metals), sample results greater than the instrument detection limit but less than five times $(5 \mathrm{X})$ the amount found in an associated blank are qualified as undetected $(\mathrm{U})$. There are no common metallic laboratory contaminants, so the sample result is never altered using a " $10 \mathrm{X}$ rule." When applying the $5 \mathrm{X}$ criteria to soil sample data or calibration blank data, the raw data results are used to evaluate and qualify the reported results on the Certificate of Analysis or CLP's Form I.

Surrogate spikes, or system monitoring compounds, are added to the environmental samples analyzed by chromatographic techniques for VOCs, SVOCs, gasoline, and diesel. Surrogate compounds area analytes that are not expected to be present in associated environmental samples, but behave similar to target compounds chromatographically. Known amounts of each surrogate are added to the samples prior to analysis of nonextractable methods. Extractable methods require known amounts of each surrogate added to the samples during sample preparation procedure. The percent recoveries of these surrogate compounds give some measure of the anticipated recoveries of the target compounds whose chromatographic behavior they mimic. 
If any surrogate percent recoveries are out of the acceptable range (which differs for each surrogate in each method), laboratory protocol requires the sample be reprepared and/or reanalyzed. When the surrogate recoveries are acceptable on the second run, only the second analysis results are reported. When both analyses yield the same unacceptable range, the results of both analyses are reported.

The evaluation of surrogate spike recovery results is subjective and requires analytical experience, but data qualifications are based on a review of all data from the SDG and considering the complexity of the sample matrix. The functional guidelines require the data reviewer to exercise professional judgement in reviewing surrogate data and qualifying associated data as estimated ( $\mathrm{J}$ or UJ, for detections or nondetections, respectively) or unusable (R). Documentation of data qualification resulting from the application of these guidelines is retained in the project files as both hard copy and electronic media.

One laboratory duplicate analysis for metals per matrix was performed for each SDG that reported total metals. The duplicate results are compared to the results of the original sample to give a measure of analytical laboratory precision. An RPD control limit of \pm 20 percent for water and \pm 35 percent for soil shall be used for original and duplicate values greater than or equal to $5 \mathrm{X}$ the CRDL. A control limit of \pm CRDL for water and $\pm 2 X$ CRDL for soil shall be used if the original or duplicate value is less than $5 \mathrm{X}$ the CDRL. If the results from a duplicate analysis for a particular analyte fall outside of the control limits, the EPA Functional Guidelines for Inorganic Data Review (EPA, 1994c) call for all results for that analyte in all associated samples of the same matrix to be qualified as estimated $(\mathrm{J})$. Documentation of data qualifications resulting from the application of these guidelines is retained in the project files as both hard copy and electronic media.

The Functional Guidelines for Inorganic data review has "no review criteria for field duplicate analyses comparability." Professional judgment will be applied to the RPD results. Soil field duplicate results will have a greater variance than water matrices, due to difficulties associated with collecting identical field soil samples.

Laboratory control samples, also known as blank spikes, consist of known quantities of target compounds added to purified sand and/or deionized, distilled water and analyzed along with the 
environmental samples in the sample delivery group. The percent recoveries of the compounds in the LCS give a measure of laboratory accuracy. The functional guidelines call for the data reviewer to use professional judgement to qualify associated data according to established criteria.

Documentation of data qualification resulting from the application of these guidelines is retained in project files as both hard copy and electronic media.

\section{A.4.8 Field Nonconformances}

One nonconformance was reported in January 1999 for this project. A total of 17 soil samples from boreholes BG1, BG2, and NB1 were not analyzed for SVOCs or TPH-diesel as required in the CAIP (DOE/NV, 1998). The NDEP and DOE/NV were notified of this nonconformance. Justification for the decision not to resample the affected boreholes was based on process knowledge, field data generated during the site investigation, and laboratory data from other boreholes. NB1 was drilled in Area 2 where process knowledge and excavation data indicate that this area was probably used as a loading/unloading area for animal trailers and is not suspected to have contamination associated with SVOCs and TPH-diesel. Field observations also indicate there was no soil staining or elevated field screening results for this area (see Section A.2.2.4). Analytical data generated from other boreholes drilled within the remaining areas of concern at the DTRSA confirmed that SVOCs and TPH-diesel were either not present, or if present, in concentrations below PALs. Boreholes BG1 and BG2 were primarily drilled and sampled to generate background data for radionuclides and RCRA metals. The original sampling plan should not have included SVOCs and TPH-diesel since these constituents should not be present in undisturbed locations.

\section{A.4.9 Laboratory Nonconformances}

Laboratory nonconformances are generally due to inconsistencies in analytical instrumentation operation, sample preparation, extractions, and fluctuations in internal standard and calibration results. A laboratory nonconformance was documented for this project. This nonconformance has been accounted for in the data qualification process. Data were rejected as a result of this nonconformance. The results of the investigation were not affected by the rejected data. 


\section{A.5.0 Summary}

Analysis of the data generated from sampling activities conducted during corrective action investigation activities at the DTRSA indicates the following:

- Three areas of concern were identified during excavation activities. The boundaries of all three areas were delineated by disturbed subsurface geology. Area 6 was identified as the burial pit and contained radiologically contaminated debris consisting of plastic, wire, lumber and other miscellaneous items. Area 2 was identified as a loading/unloading area for the animal trailers as evidenced by shoring consisting of plywood and metal posts. The southern half of the DTRSA contained the decontamination facility.

- With the exception of arsenic, the PALs were not exceeded for total VOCs, total SVOCs, $\mathrm{TPH}$, and total RCRA Metals for any of the samples collected from the subsurface at the DTRSA site.

- Arsenic concentrations were detected above the industrial PRG level in all samples collected for total RCRA metal analysis; however, these concentrations are not significantly different than background concentrations detected in the two background boreholes drilled near the DTRSA site. Based on the background concentrations and data from Shacklette and Boerngen (1984), arsenic is perceived to be naturally occurring at these levels.

- Radiological field screening and swipes detected elevated gamma counts, elevated alpha counts, and removable alpha on debris encountered in the Area 6 burial pit but not on associated soils. Beta was below field screening levels.

- Preliminary action levels for isotopic plutonium and uranium were not exceeded for any of the soil samples collected from the subsurface at the DTRSA site. 


\section{A.6.0 References}

Atlan-Tech. 1992. Environmental Monitoring Report for the Proposed Ward Valley California LLRW Facility. Rosewall, GA: Atlan-Tech Inc.

BN, see Bechtel Nevada.

Bechtel Nevada. 1998. Bechtel Nevada Analytical Services Laboratory Procedures Manual. Las Vegas, NV.

Bechtel Nevada. 1999. Correspondence from Bechtel Nevada Survey Department to D. Arnold (SAIC) regarding coordinates surveyed on 2-19-99 for the Double Tracks RADSAFE Area Investigation, electronic file DBL TRK99.UTM. Las Vegas, NV.

DOE/NV, see U.S. Department of Energy, Nevada Operations Office.

EG\&G, see EG\&G/Energy Measurements.

EG\&G/Energy Measurements. 1980. Aerial photograph, perf \#3309, frame \#092, 09 August. Nellis Air Force Base, NV: Remote Sensing Laboratory Photo Archives.

EPA, see U.S. Environmental Protection Agency.

FFACO, see Federal Facility Agreement and Consent Order.

Federal Facility and Consent Order. 1996 (as amended). Agreed to by the Nevada Division of Environmental Protection, the U.S. Department of Energy, and the U.S. Department of Defense.

Horwitz, E.P., M.L. Dietz, R. Chiarizia, H. Diamond, A.M. Essling, and D. Graczyk. 1992. "Separation and Preconcentration of Uranium from Acidic Media by Extraction Chromatography." In Analytica Chimica Acta, 266: 25-37.

Horwitz, E.P., R. Chiarizia, M.L. Dietz, H. Diamond, D.M. Nelson. 1993. "Separation and Preconcentration of Actinides from Acidic Media by Extraction Chromatography." In Analytica Chimica Acta, 281: 361-372.

IT, see IT Corporation.

IT Corporation. 1998a. Digital photograph "Image 26" and "Image 27" of trench number 6NT1 at Double Tracks RADSAFE Area, Nellis Air Force Range 71N, 20 November. Las Vegas, NV: IT Digital Photograph Database. 
IT Corporation. 1998b. Site-Specific Health and Safety Plan for CAU 486, Double Tracks RADSAFE Area, Subsurface Investigation, Nellis Air Force Range. Las Vegas, NV.

McArthur, R.D. and F.L. Miller. 1989. Off-Site Radiation Exposure Review Project (ORERP), Phase II Soil Program, DOE/NV/10384-23. Las Vegas, NV: Desert Research Institute.

NAC, see Nevada Administrative Code.

Nevada Administrative Code. 1998. NAC 445A.227, "Contamination of soil: Order by director of corrective action; factors to be considered in determining whether corrective action is required." Carson City, NV.

NRC, see U.S. Nuclear Regulatory Commission.

SAIC, see Science Applications International Corporation.

Science Applications International Corporation, R.E. Wright Environmental, Inc. 1998. First Quarter 1998 Surface Geophysical Survey Report Double Tracks Rad Safe Area Corrective Action Unit 486 Corrective Action Site 71-23-001-71DT at the Tonopah Test Range, Tonopah, Nevada, R.E. Wright Project 01-1408-08-3610-000. Middletown, PA.

Shacklette, H.T. and J.G. Boerngen. 1984. Element Concentrations in Soils and Other Surficial Materials of the Conterminous United States, U.S. Geological Survey Professional Paper 1270. Washington, DC: U.S. Government Printing Office.

U.S. Department of Energy, Nevada Operations Office. 1996a. Corrective Action Unit Work Plan, Tonopah Test Range, Nevada, DOE/NV--443, Rev. 0. Las Vegas, NV: IT Corporation.

U.S. Department of Energy, Nevada Operations Office. 1996b. Industrial Sites Quality Assurance Project Plan, Nevada Test Site, Nevada, Rev. 1, DOE/NV--372. Las Vegas, NV.

U.S. Department of Energy, Nevada Operations Office. 1998. Corrective Action Investigation Plan for Corrective Action Unit 486: Double Tracks RADSAFE Area, Nellis Air Force Range, Nevada, DOE/NV--523, Rev. 0. Las Vegas, NV: IT Corporation.

U.S. Environmental Protection Agency. 1987. Data Quality Objectives for Remedial Response Activities, EPA/540/G-87-003. Washington, DC.

U.S. Environmental Protection Agency. 1994a. Guidance for the Data Quality Objectives Process, EPA QA/G-4. Washington, DC.

U.S. Environmental Protection Agency. 1994b. Contract Laboratory Program National Functional Guidelines for Organic Data Review, EPA 540/R-94/012. Washington, DC. 
U.S. Environmental Protection Agency. 1994c. Contract Laboratory Program National Functional Guidelines for Inorganic Data Review, EPA 540/R-94/013. Washington, DC.

U.S. Environmental Protection Agency. 1996. Test Methods for Evaluating Solid Waste, Physical/Chemical Methods, SW-846, CD ROM. Washington, DC.

U.S. Environmental Protection Agency. 1998. Memo from S.J. Smucker to PRG Table Mailing List regarding Region 9 Preliminary Remediation Goals (PRGs), 1 August.

San Francisco, CA.

U.S. Nuclear Regulatory Commission. 1997. Multi-Agency Radiation Survey and Site Investigation Manual (MARSSIM), NUREG-1575/EPA 402-R-97-016. Prepared by the NRC, EPA, DOE, and DoD. Washington, DC: U.S. Government Printing Office. 


\section{Appendix B}

Soil Boring Logs 


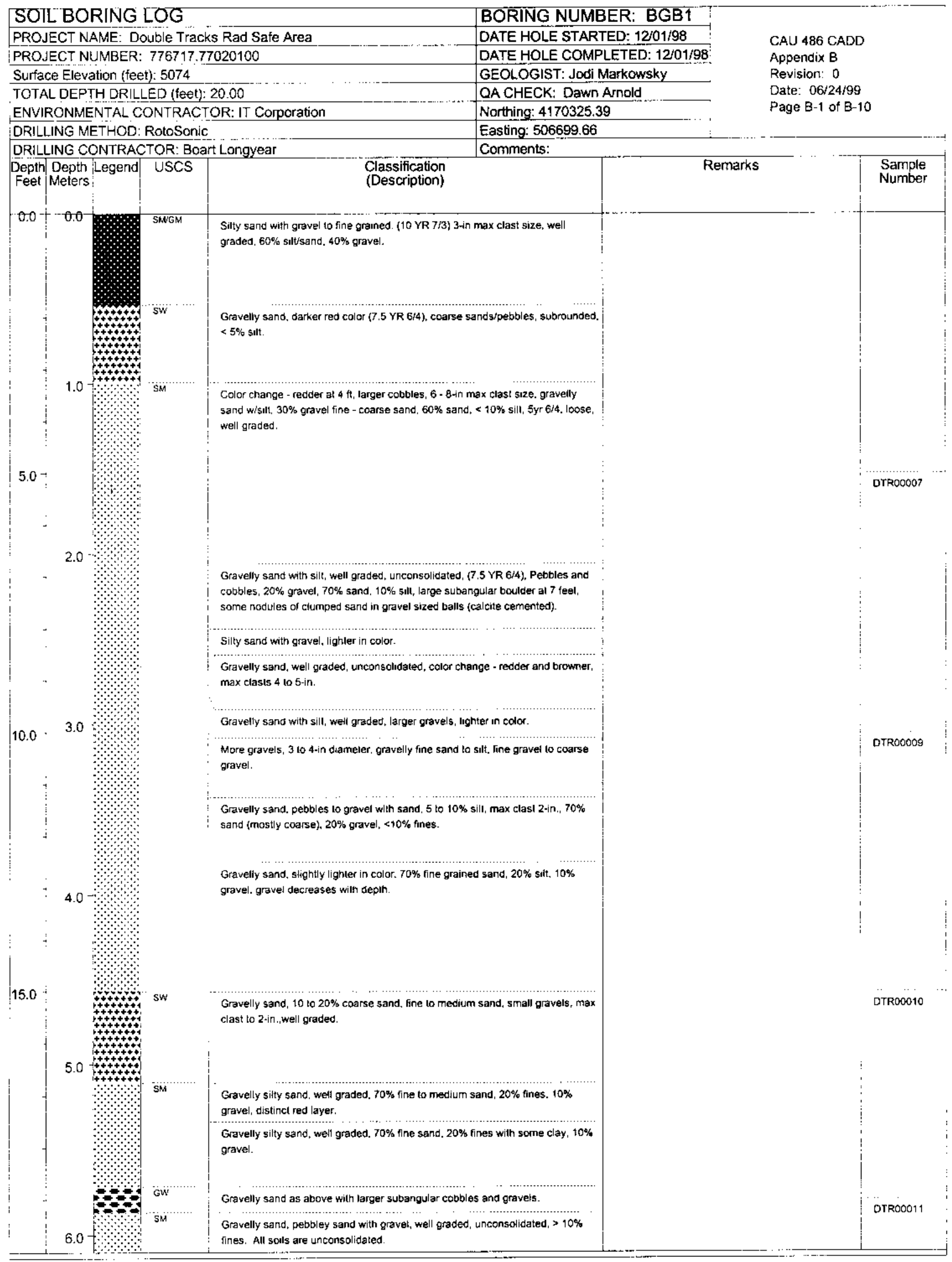


Depthi Depth |Legend USCS

Feet |Meters Easting: 506568.58

\begin{tabular}{l|l|lll}
0.0 & 0.0 & & \\
& & & & \\
& & &
\end{tabular} Comments:

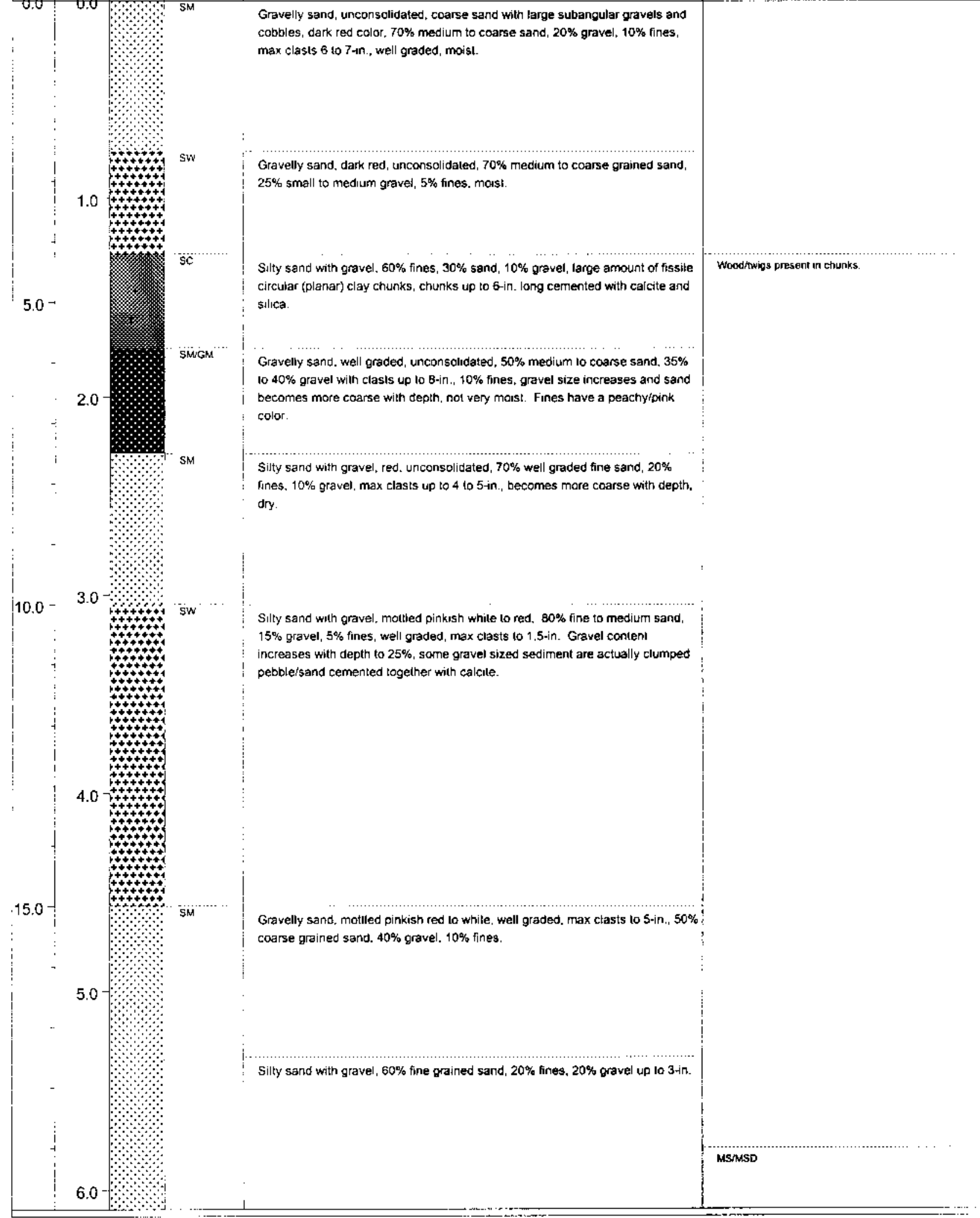


PROJECT NAME: Double Tracks Rad Safe Area

PROJECT NUMBER: 776717.77020100

Surface Elevation (feet): 5063

TOTAL DEPTH DRILLED (feet): 20.00

ENV|RONMENTAL CONTRACTOR: IT Corporation

DRILLING METHOD: RotoSonic

DRILLING CONTRACTOR: Boart Longyear

Depth Depth Legend USCS

Feet Meters

$0.0+0.0-\cdots$

Silty sand, $80 \%$ fine to medium sand, $15 \%$ fines, $5 \%$ subangular gravel up to 3-in., well gradect. organic material present.

Sity sand, $75 \%$ medium to coarse grained sand. $15 \%$ gravel, $10 \%$ fines, well graded, loose, dry. Gravels become larger with depth up to 3-in., some fines begin to adhere to the gravels

DATE HOLE STARTED: $12 / 01 / 98$

DATE HOLE COMPLETED: $12 / 01 / 98$

GEOLOGIST: Jodi Markowsky

QA CHECK: Dawn Arnold

Northing: 4170315.21

Easting: 506599.25

Comments:

Classification

Classification
(Description)

(

Remarks

CAU 486 CADD

Appendix B

Revision: 0

Date: $06 / 24 / 99$

Page B-3 of B-10

Sancty gravel. $80 \%$ subangular gravel. $25 \%$ sand, $<5 \%$ fines, partıal consolidation of gravel and sand into clumps cemented with calcile like tackground boring.

Sandy gravel, rusl color, $90 \%$ gravel, $10 \%$ sand, small amount of calcite coaling on gravels.

Sandy gravel, with some lines, well graded, clast up lo 2-in. wilh calcile coating.

Gravel layer, max clasts ug to 4-in., no fines, well graded.

Gravelly sand, $70 \%$ sand. $20 \%$ gravel, $10 \%$ fines, small flakes of $\mathrm{CaCO}$

Gravelly sand as abovee, fissile chunks of clay/sill with small gravel/pebbles up intervals.

DTR00024

DTR00025

DTR00026

DTROOO27 to 2 -in.

Gravelly sand, pirk, $70 \%$ sand, $20 \%$ gravel, some large gravels up to 6 -in., $10 \%$ fines. well graded, white flecks of $\mathrm{CaCO} 3$ throughout. 
BORING NUMBER: NB2

DATE HOLE STARTED: $12 / 02 / 98$

PROJECT NUMBER: 776717.77020100

Surface Elevation (feet) 5064

TOTAL DEPTH DRILLED (feet): 20.00

ENVIRONMENTAL CONTRACTOR: IT Corporation

DRILLING METHOD: RotoSonic

DRILLING CONTRACTOR: Boart Longyear

Depth| Depth Legend' USCS

Feet : Meters

$0.0-0.0$

1.0

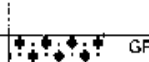

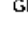

GP

Poorly graded gravels, 10 YR 6/4, unconsolidated, $85 \%$ large angular boulders and cobbles. max clasts $106-10 ., 10 \%$ sand, $<5 \%$ fines, dry.

Sandy gravel, unconsolidated, $85 \%$ gravel. $15 \%$ sand, no fines, well graded, caliche coatings on gravels, dry.

Classification
(Description)
DATE HOLE COMPLETED: $12 / 02 / 98$ GEOLOGIST: Jodi Markowsky QA CHECK: Dawn Annold Northing: 4170300.07 Easting: 506638.78 Comments:

Poorly graded gravels, pea size gravel, gravel up to $1 / 2 \cdot$-in., no fines $<5 \%$.

Gravelly sand, well graded, partially consolidaled, $70 \%$ fine to coarse sand, $20 \%$ gravel up lo 2 -inn., $10 \%$ fines, clumpy sandipebbles cemented logether like background borehole.

Gravelly sand, unconsolidaled, pea sized gravel and sand remain dominant, dry.

Danker layer. reddish brown. with clumps of 5 mall gravel

Sandy gravel, $60 \%$ gravelup to 4 -in., 30\% sand, $10 \%$ fines, calıche disseminated Ihroughout, gravel increases whth depth.

White layer up to 5-in thick, caliche layer present.

Caliche layer as above.

Silty sand. unconsolidaled, $80 \%$ sand, $10 \%$ gravel, $10 \%$ lines, well graded, dry.

SM

DTR00036

DTRO0037

Gravelly sand, motlled wilt dark red patches. $60 \%$ fine to medium sand, $30 \%$ gravel up to $4-11$., $10 \%$ fines, small amount of caliche.

Appendix B

Revision: 0

06/24/99

Page B-4 of B-10

$$
\text { Int }
$$

Interface with native soll at $5 \mathrm{ft}$

DTRO0032

Pund samples collected trom 5 to 10 if in 1 - fl intervals.

OTR00035
Black Irash bag present at 2 ft

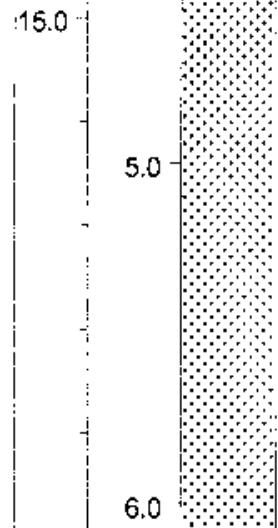




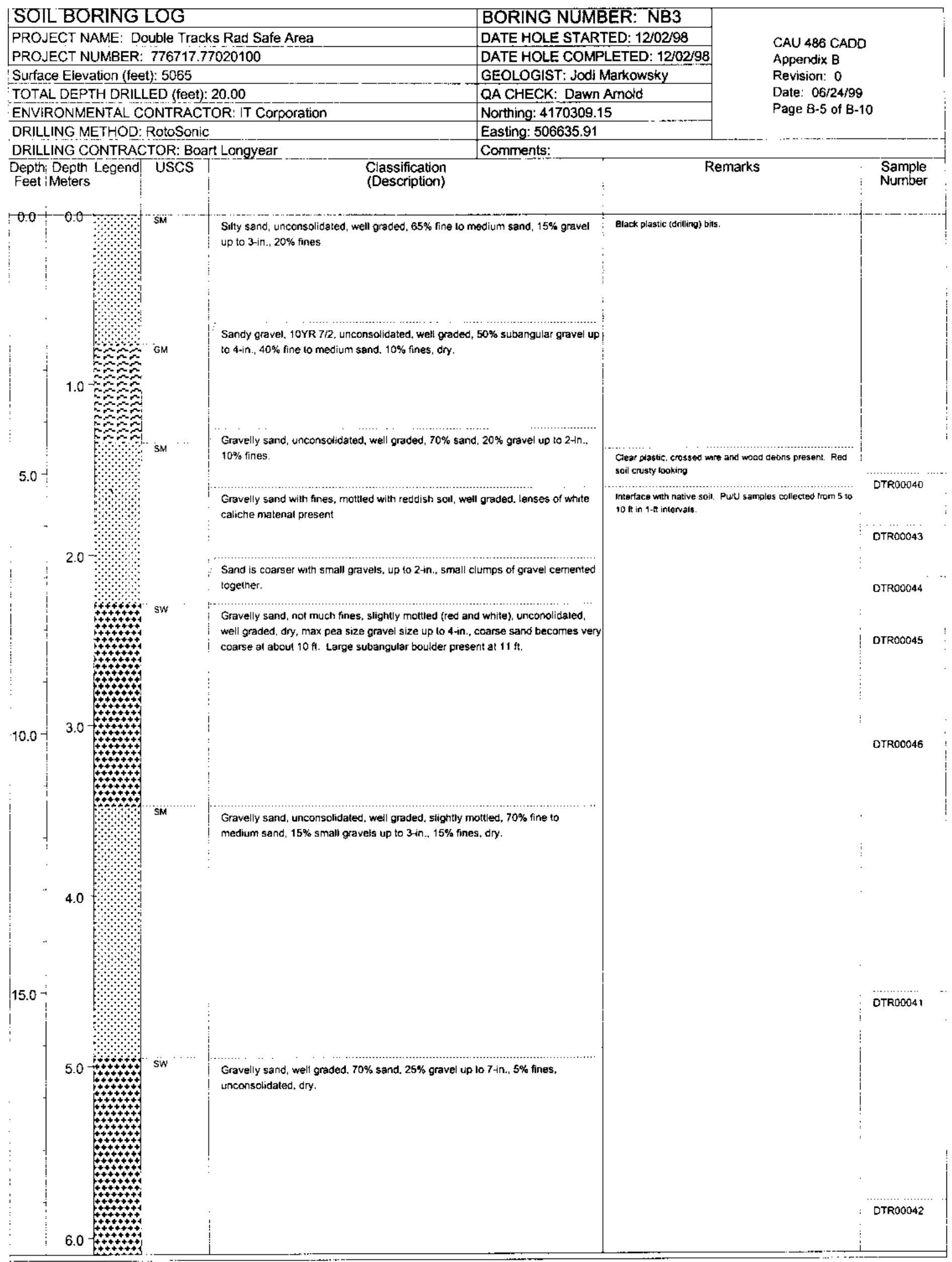




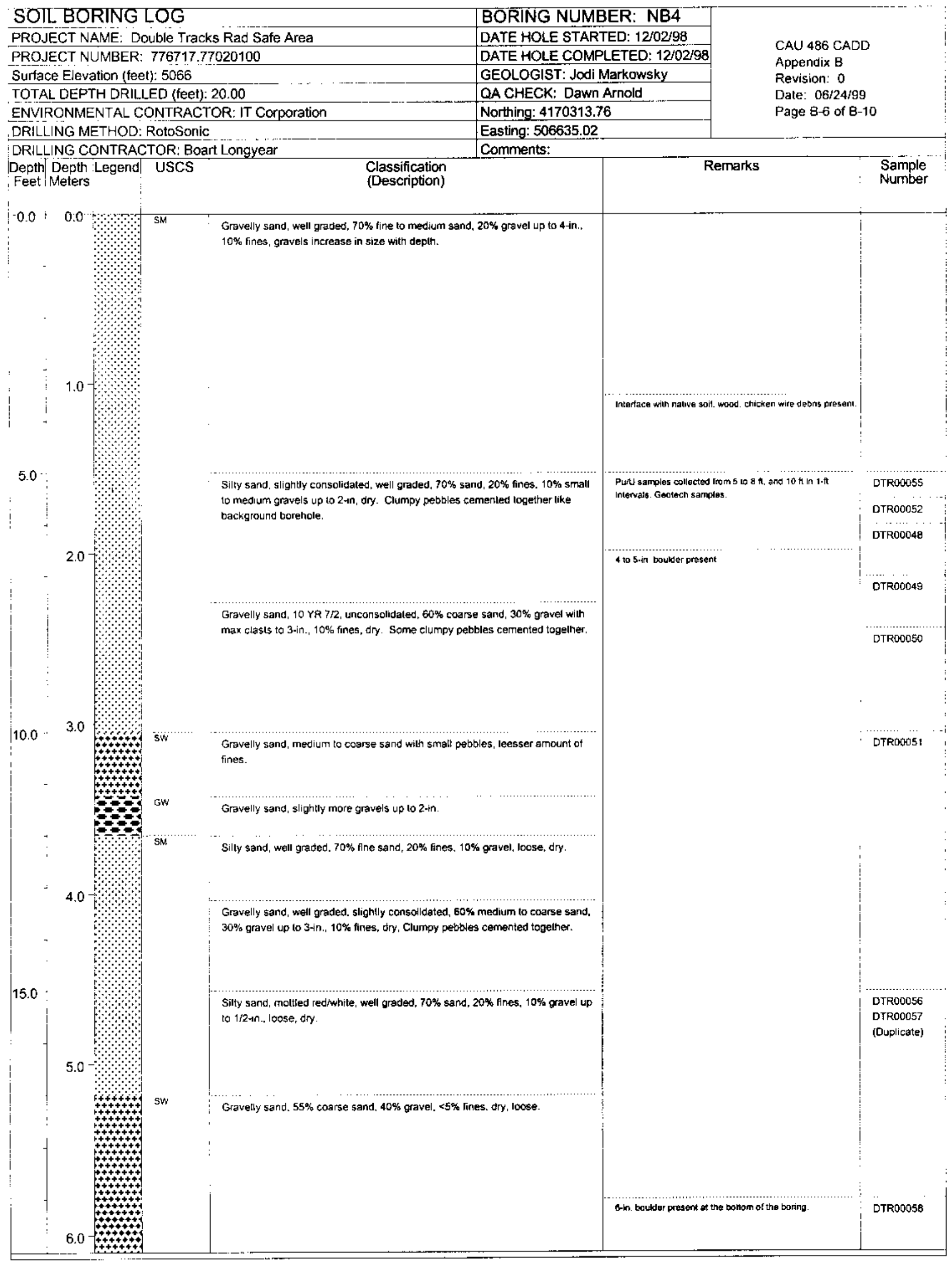



GEOLOGIST: jodi Markowsky

Appendix B

ENVIRONMENTAL CONTRACTOR: IT Corporation QA CHECK: Dawn Arnold

Revision: 0

DRILLING METHOD: RotoSonic

DRIELING CONTRACTOR: Boart Longyear

Depth Depth Legend USCS

Feet Meters

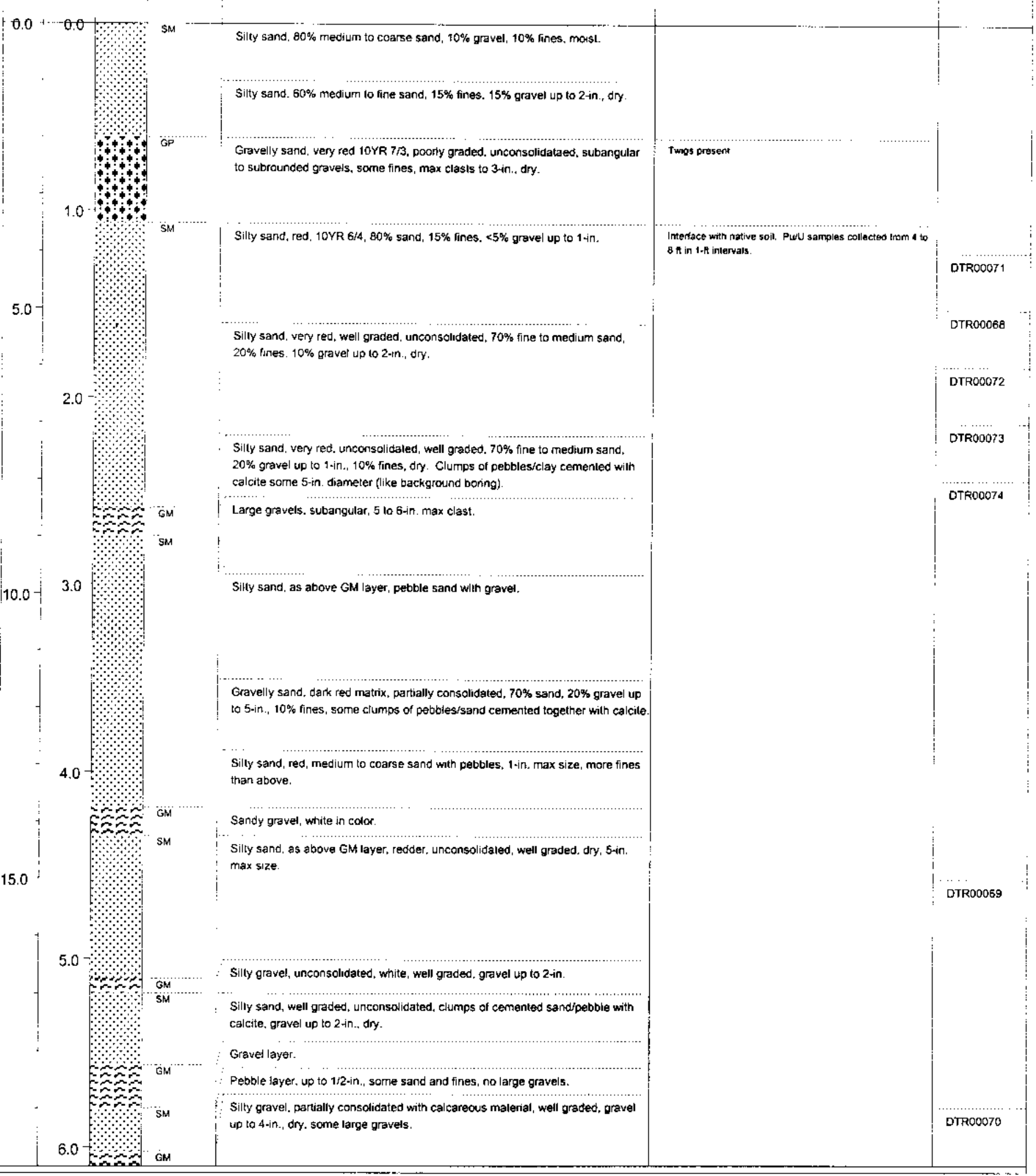




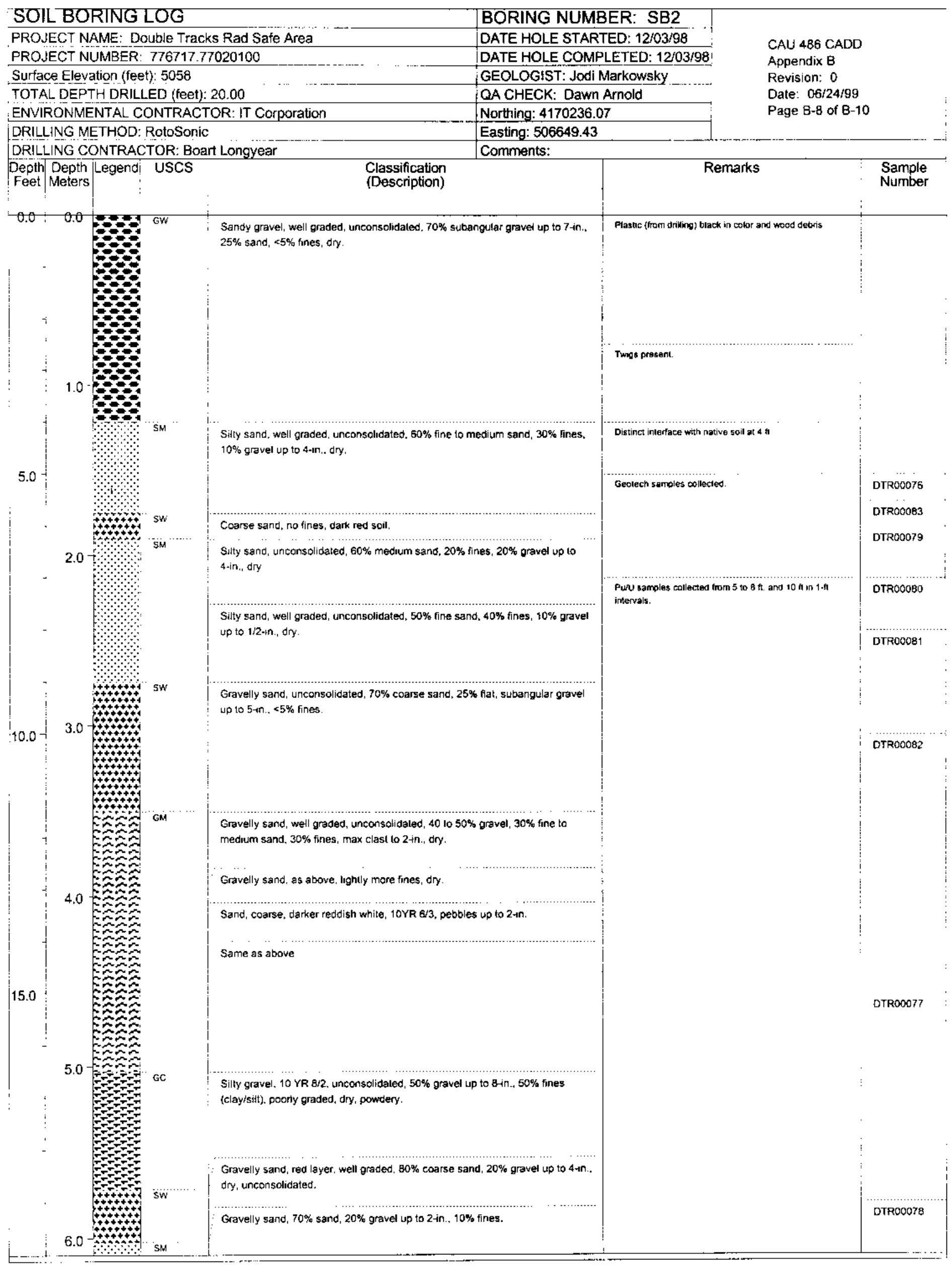




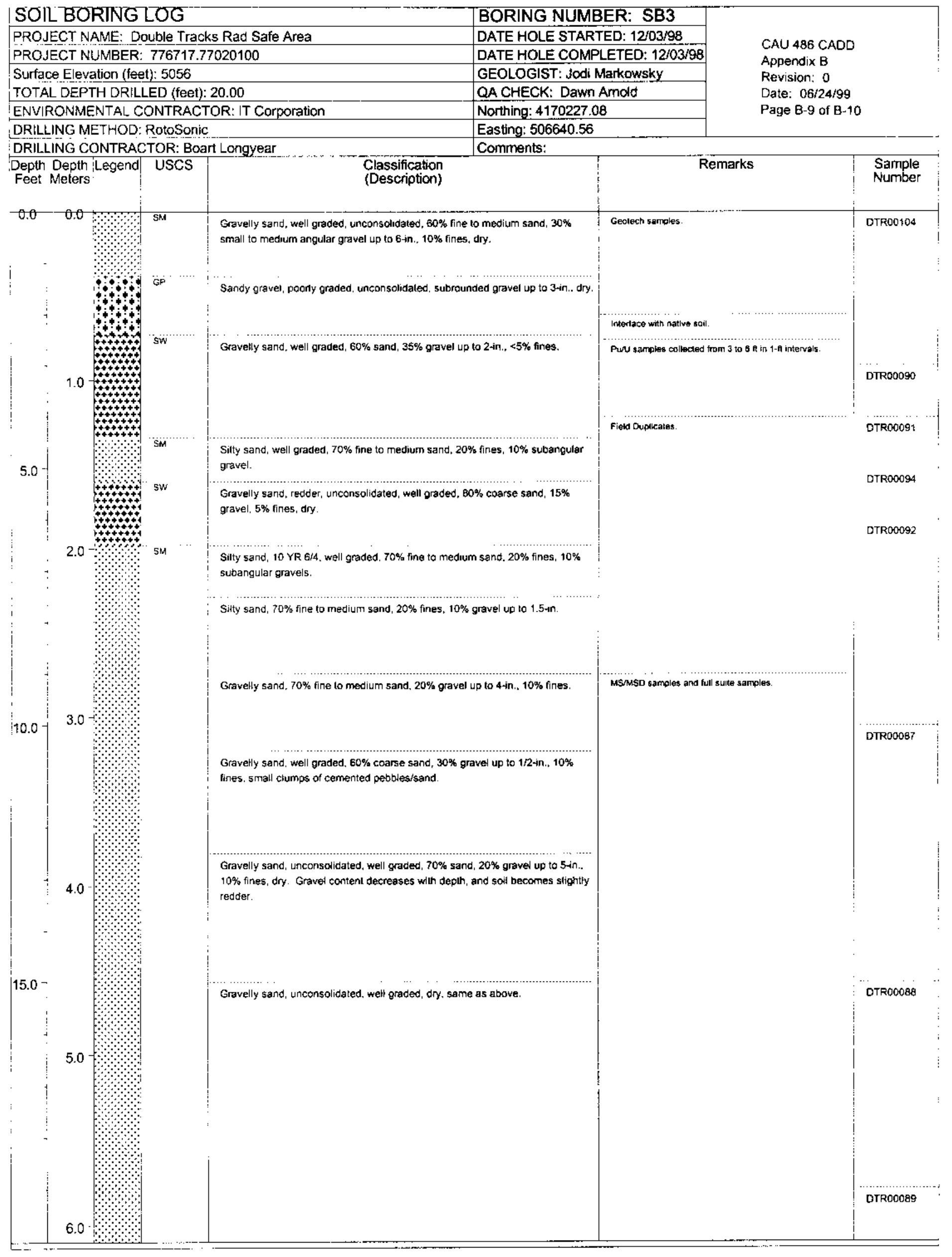




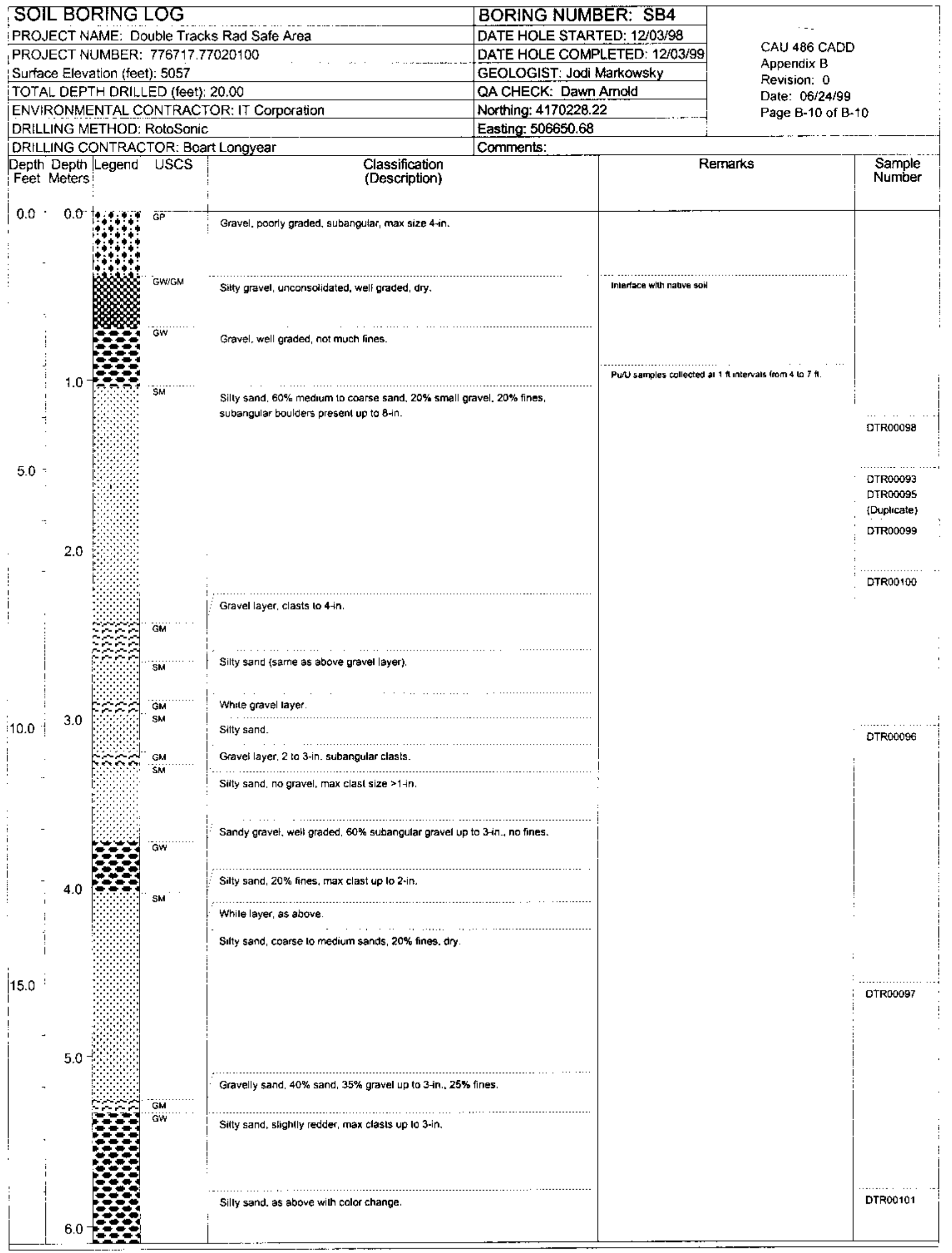




\section{Appendix C \\ Cost Estimates}

(As received from Bechtel Nevada [BN]) 


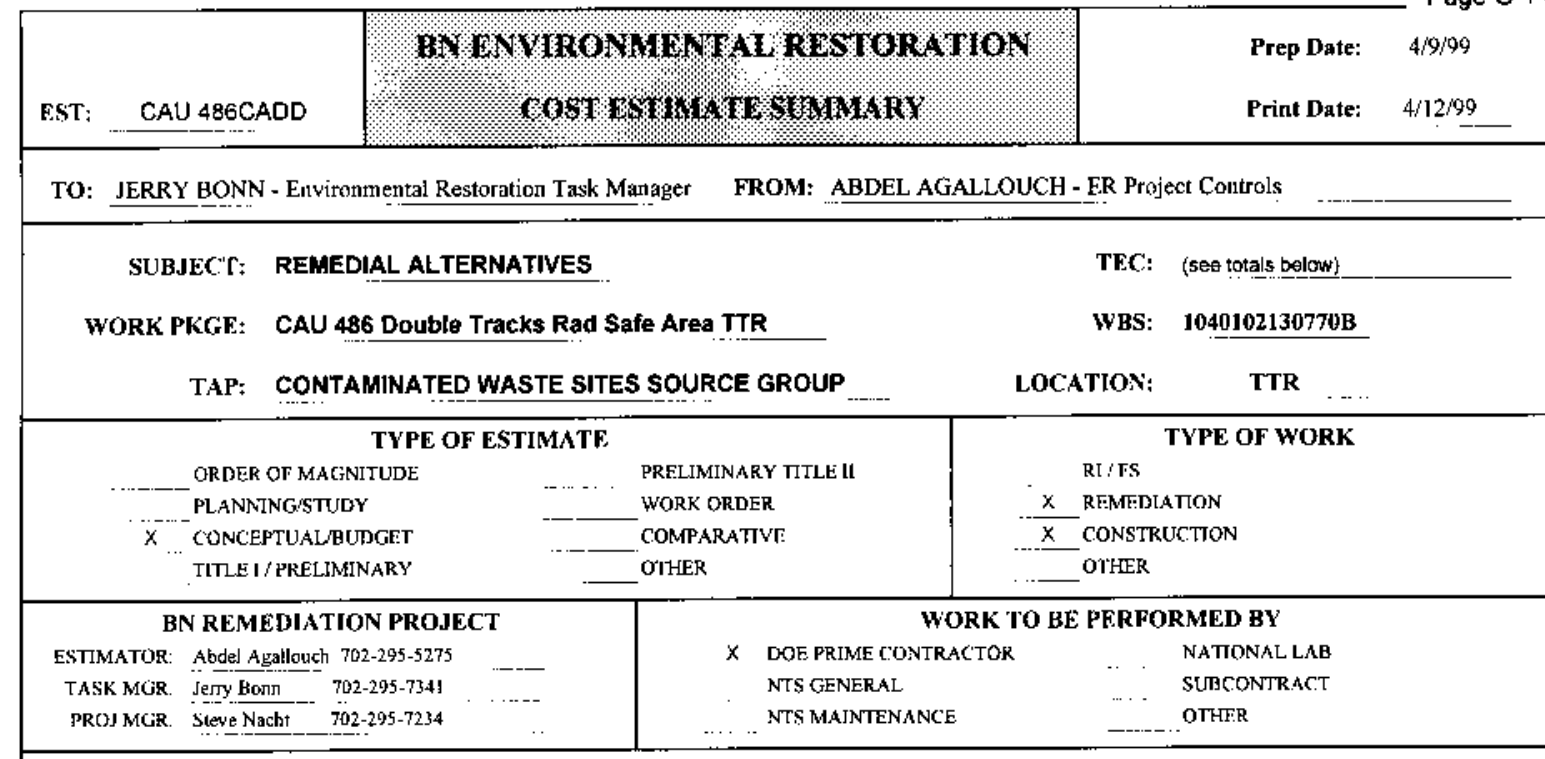

\section{STATEMENT OF WORK:}

- This estimate bas been prepared to provide remedial altcnative costs for the closure of Corrective Aclion Unit (CAU) 486, an environmental restoration site listed in the Federal Facilities and Cornsent Order (FFACO). CAU 486 is specifically described as the Double Tracks Rad Safe Area. Two alternatives will be evaluated for closure of the site: I) No Further Action, II) Clean Closure by Excavation and Disposal. This estimate will be used to identify the most cost effective altemative for clusure of the site while being protective of hutrats beaith and the environment. Total estimated costs are intended for comparative analysis of remectial field work and tield management only. Cosss for project management, plan preparation (HASP, Field manlagement Plan, CAP, CR or readiness revicw), project support, or other overbead functions are not included.

\section{SCOPE}

Provide site closure using one of the following alternatives:

1) NO FUR THER ACTION

1) CLEAN CI.OSIRE BY EXCAVATION AND DISPOSAL

\section{BASIS OF ESTIMATE AND ASSUMPTIONS}

\section{Alternative 1 : No Futher Action}

- No actious or administrative contruls implied; no associated costs.

\section{Alternative Ui Clean Closure by Excavation and Dispesal}

- Clean clusure activities are only required at the Area 6 Burial Pit

- On-site soil andl clean soil from a nearby location (Arca 3 horrow pile) will be used to backfill the excavation to minimize surface depression.

- Excavate a minimum of 3 two-foot wide trenches to a minimum depth of 5 feet below ground suffice. One trencl will be excavated in the center of the defined Burial Pit (75 feet long) and two trenches ( 30 foot long) will be excavated on either side or the center trench in the middle portion of the Burial pit.

- Fxcavation of approxinately 50 cubic yards $(2 \mathrm{ft} \times 135 \mathrm{ft} \times 5 \mathrm{ft}$ ) of non hazardous soi]

- Fxcavation of approxinately 30 cubic yards of radiological contaminated man-made debris.

- Excavated man-1nade debris wilt be screened on-site when possible.

- Five cubic yards of uncontaminated matt-made debris will be separated for disposal as solid waste. The solid waste will be containerized and slipped to the Nevada Test Site for disposal.

- The contaminated man-made debris will be surveyed/sampled on-site to delermine transportation requirements.

- The rad contanninated debris will be containerized into ten B-25 containers for shipment to the Area 6 Decontamination Facility for waste cliaracterization.

- Characterization completed at the Decontamination Facility will lye used to prepare the waste profile for the Radioactive Waste Acceptance Program.

- Asstme a total of 25 cubic yards of low level waste will be disposed of at Area 5 landfill.

- Ten verification soil samples below the removed waste will be required. Two samples will be for QA/decontamination of equipment. Samples will be analyzed for 20 -mintale garuma scan. Analysis of other parameters is not anticipated.

- Assume verification data supports the cutnpletion of clean clostre without the nced for additional excavation.

- Six bioassay samples will be analyzed for Plutonium

- Five waste characterization samples will be required. Samples will be analyzed fur 20-minute gamma spectroscopy. Analysis of other parameters is not anticipated.
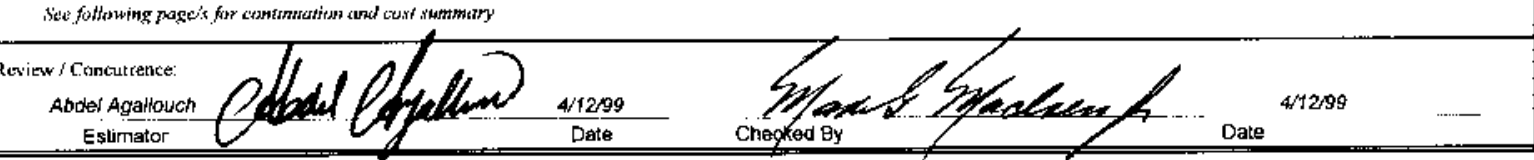


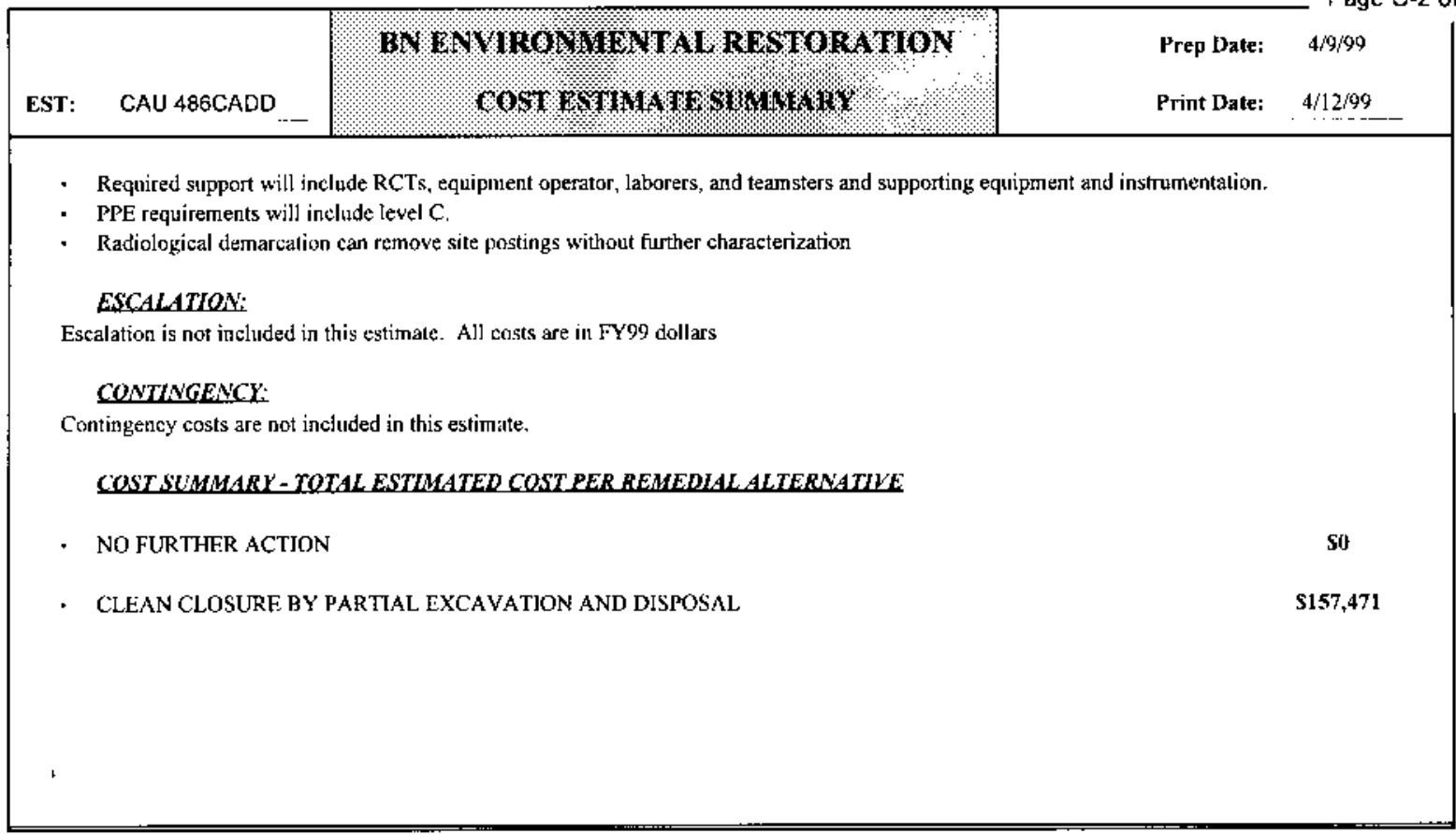




\section{Appendix D}

\section{Response to NDEP Comments}




\section{NEVADA ENVIRONMENTAL RESTORATION PROJECT}

DOCUMENT REVIEW SHEET

\begin{tabular}{|c|c|c|c|c|c|}
\hline \multicolumn{4}{|c|}{ 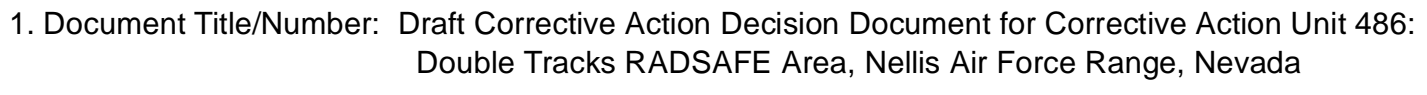 } & \multicolumn{2}{|l|}{ 2. Document Date: April 1999} \\
\hline \multicolumn{4}{|c|}{ 3. Revision Number: 0} & \multicolumn{2}{|c|}{ 4. Originator/Organization: IT Corporation } \\
\hline \multicolumn{4}{|c|}{ 5. Responsible DOE/NV ERP Subproject Mgr.: Janet Appenzeller-Wing } & \multicolumn{2}{|l|}{ 6. Date Comments Due: } \\
\hline \multicolumn{6}{|c|}{ 7. Review Criteria: Full } \\
\hline \multicolumn{4}{|c|}{ 8. Reviewer/Organization/Phone No.: Michael McKinnon, NDEP, 486-2856 } & \multicolumn{2}{|l|}{ 9. Reviewer's Signature: } \\
\hline $\begin{array}{l}\text { 10. Comment } \\
\text { Number/ } \\
\text { Location }\end{array}$ & 11. Type* & 12. Comment & \multicolumn{2}{|c|}{ 13. Comment Response } & 14. Accept \\
\hline $\begin{array}{l}\text { 1) Pages } \\
\text { ES-1, } 3^{\text {rd }} \\
\text { Paragraph, } \\
\text { Next to Last } \\
\text { Sentence }\end{array}$ & & $\begin{array}{l}\text { "...No contaminants were detected above preliminary action } \\
\text { levels..." This sentence should be prefaced with the following, "With } \\
\text { the exception of this excavated debris (which was not } \\
\text { characterized),..." }\end{array}$ & \multicolumn{2}{|c|}{$\begin{array}{l}\text { Sentence changed and second sentence added. Text now } \\
\text { reads: "No contaminants were detected above preliminary } \\
\text { action levels in soil samples analyzed from Phase II } \\
\text { activities. Debris excavated during Phase I activities was } \\
\text { not characterized." }\end{array}$} & Yes \\
\hline $\begin{array}{l}\text { 2) Page } 8 \text {, } \\
\text { Section 3.1.1, } \\
3^{\text {rd }} \text { Sentence }\end{array}$ & & $\begin{array}{l}\text { Amend sentence to read, "...Based on the results of this evaluation, } \\
\text { and with the exception of the uncharacterized debris excavated from } \\
\underline{\text { Area } 6}, \text { no COCs were identified above PALs..." }\end{array}$ & \multicolumn{2}{|c|}{$\begin{array}{l}\text { The suggested text has been added and the sentence now } \\
\text { reads: "Based on the results of this evaluation, and with the } \\
\text { exception of the uncharacterized debris excavated from } \\
\text { Area } 6, \text { no COCs were identified above PALs..." }\end{array}$} & Yes \\
\hline
\end{tabular}

${ }^{a}$ Comment Types: $M=$ Mandatory, $\mathrm{S}=$ Suggested.

Return Document Review Sheets to DOE/NV Environmental Restoration Division, Attn: QAC, M/S 505. 


\section{Distribution}

*Provide copy in distribution of Rev. 0 and subsequent revisions, if applicable. Copies of the NDEP-approved document will be distributed to others.

Paul J. Liebendorfer

State of Nevada

Bureau of Federal Facilities

Division of Environmental Protection

333 W. Nye Lane, Room 138

Carson City, NV 89706-0851

Michael McKinnon

State of Nevada

Bureau of Federal Facilities

Division of Environmental Protection

555 E. Washington, Suite 4300

Las Vegas, NV 89101

Sabrina Lawrence

Environmental Restoration Division

DOE/Nevada Operations Office

P.O. Box 98518, M/S 505

Las Vegas, NV 89193-8518

Janet Appenzeller-Wing

Environmental Restoration Division

DOE/Nevada Operations Office

P.O. Box 98518, M/S 505

Las Vegas, NV 89193-8518

Kevin Cabble

Environmental Restoration Division

DOE/Nevada Operations Office

P.O. Box 98518, M/S 505

Las Vegas, NV 89193-8518

Jerry Bonn

Bechtel Nevada

P.O. Box 98521, M/S NTS306

Las Vegas, NV 89193-8521
2 (Controlled)*

1 (Controlled)*

1 (Controlled)*

1 (Uncontrolled)*

1 (Uncontrolled)*

1 (Uncontrolled)* 
Steve Nacht

Bechtel Nevada

P.O. Box 98521, M/S NTS306

Las Vegas, NV 89193-8521

Dustin Wilson

SAIC

P.O. Box 93838

Las Vegas, NV 89193

IT Corporation Central Files

IT Corporation

P.O. Box 93838

Las Vegas, NV 89193

Jeffrey Johnson

IT Corporation

P.O. Box 93838

Las Vegas, NV 89193

Dawn Arnold

SAIC

P.O. Box 93838

Las Vegas, NV 89193

Technical Information Resource Center

DOE/Nevada Operations Office

P.O. Box 98518, M/S 505

Las Vegas, NV 89193-8518

U.S. Department of Energy

Office of Scientific and Technical Information

P.O. Box 62

Oak Ridge, TN 37831

Manager Southern Nevada FFACO

Public Reading Room

P.O. Box 98521, M/S NLV040

Las Vegas, NV 89193-8521
1 (Uncontrolled)*

1 (Uncontrolled)*

1 (Uncontrolled)*

1 (Uncontrolled)*

1 (Uncontrolled)*

1 (Uncontrolled)

1 (Uncontrolled, electronic copy)

1 (Controlled)

1 (Uncontrolled) 
Manager Northern Nevada FFACO

1 (Uncontrolled)

Public Reading Room

c/o Rosa Silver

IT Corporation

P.O. Box 93838

Las Vegas, NV 89193

Rosa Silver

1 (Controlled)

FFACO Public Reading Room Coordinator

IT Corporation

P.O. Box 93838

Las Vegas, NV 89193

Eloisa V. Hopper

3 (Controlled)*

U.S. Air Force

$99 \mathrm{ABW} / \mathrm{EM}$

4349 Duffer Dr., Suite 1601

Nellis AFB, NV 89191-7007

Major Roger Schofield

1 (Controlled)*

U.S. Air Force

AWFC RMO/RML

3770 Duffer Dr.

Nellis AFB, NV 89191-7001 